University of Louisville

ThinkIR: The University of Louisville's Institutional Repository

$5-2005$

\title{
Disciplining P-12 public school personnel for off-duty conduct : an analysis of the judicial response.
}

Ruth Louise Davison 1965-

University of Louisville

Follow this and additional works at: https://ir.library.louisville.edu/etd

\section{Recommended Citation}

Davison, Ruth Louise 1965-, "Disciplining P-12 public school personnel for off-duty conduct : an analysis of the judicial response." (2005). Electronic Theses and Dissertations. Paper 322.

https://doi.org/10.18297/etd/322

This Doctoral Dissertation is brought to you for free and open access by ThinkIR: The University of Louisville's Institutional Repository. It has been accepted for inclusion in Electronic Theses and Dissertations by an authorized administrator of ThinkIR: The University of Louisville's Institutional Repository. This title appears here courtesy of the author, who has retained all other copyrights. For more information, please contact thinkir@louisville.edu. 
DISCIPLINING P-12 PUBLIC SCHOOL PERSONNEL FOR OFF-DUTY CONDUCT: AN ANALYSIS OF THE JUDICIAL RESPONSE

\author{
By \\ Ruth Louise Davison \\ B.A., Mary Washington College, 1987 \\ M.Div., Southern Baptist Theological Seminary, 1993 \\ M.A., University of Louisville, 2002

\begin{abstract}
A Dissertation
Submitted to the Faculty of the

Graduate School of the University of Louisville

in Partial Fulfillment of the Requirements

for the Degree of
\end{abstract}

Doctor of Philosophy

Department of Leadership, Foundations, and Human Resource Education

University of Louisville

Louisville, Kentucky

May 2005 
Copyright 2005 by Ruth Louise Davison

All rights reserved 
DISCIPLINING P-12 PUBLIC SCHOOL PERSONNEL FOR OFF-DUTY CONDUCT: AN ANALYSIS OF THE JUDICIAL RESPONSE

\author{
By \\ Ruth Louise Davison \\ B.A., Mary Washington College, 1987 \\ M.Div., Southern Baptist Theological Seminary, 1993 \\ M.A., University of Louisville, 2002
}

A Dissertation Approved on

November 12, 2004

by the following Dissertation Committee:

John L. Strope, Jr.

Carrie G. Donald

Jayne R. Morgenthal

John F. Welsh

Paul A. Winter 


\section{DEDICATION}

I dedicate this entire writing to my father, Jon Robert Davison, who always

encouraged me to learn. He spent his life making the world a better place for his children and grandchildren. He impacted my life in immense and immeasurable ways. He will never be forgotten. 


\section{ACKNOWLEDGMENTS}

I gratefully acknowledge my family, Mom, Maggie, Jon, Kelly, Hope and Claire, for their enduring love and consistent support through my academic and professional journey. I am so grateful to have you in my life.

I extend a special acknowledgement to my chair and mentor, John Strope, for providing assistance and caring throughout this entire process. You are truly a great teacher and I am fortunate to also know you as a great friend.

I am grateful to Spalding University for supporting my educational goals. Thanks to Chris Hart for his ongoing assistance in proofing, editing, and covering so many things at work when I needed to be writing. I give a special thanks to Dan Fox and the entire Student Life team for supporting this educational task. Also, I sincerely thank Spalding President Jo Ann Rooney for allowing me the freedom to get away when I needed to focus on my writing.

I must thank my fearless editors, Dug Begley and David Barnett. You reviewed my work with precision and diligence. My finished product is a result of your efforts.

Finally, my thanks to the Dissertation Crew - Tina, Carrie, Lisa and Carol. This journey was more enjoyable because we were together. 


\title{
ABSTRACT \\ DISCIPLINING P-12 PUBLIC SCHOOL PERSONNEL FOR OFF-DUTY CONDUCT:
}

\section{AN ANALYSIS OF THE JUDICIAL RESPONSE}

\author{
Ruth Louise Davison
}

May 2005

The right to discipline a P-12 public school employee for off-duty conduct remains unclear. Historically, society has held teachers up to a higher standard of conduct than persons in most other professions. The researcher traced the teacher-as-role-model theory back to antiquity. The literature further indicated that courts often rely on the role model theory when deciding judicial challenges based on adverse employment decisions. Courts also refer to the nexus theory, demanding that a relationship exist between off-duty conduct and the job.

The following research question guided this study: When is it legal for P-12 public school employers to discipline employees for off-duty conduct? The researcher examined a broad spectrum of off-duty conduct and incorporated every case in the national reporting system related to off-duty conduct.

By using legal methodology, the researcher identified 161 cases related to the research question. Critical examination of each case provided a full understanding of the judicial response to employee challenges based on discipline for off-duty conduct. Furthermore, the researcher created a data analysis form used to capture identical 
information from each case to assess relationships among the cases. While the study did not use any form of statistical analysis, the researcher gathered quantifiable data for describing the cases collectively.

Employers prevailed in the $57 \%$ of the identified cases. While courts granted wide latitude to employers to discipline employees for off-duty conduct, employees enjoyed some constitutional protections under the right to privacy, association, speech, religion, reputation, due process and equal protection. Employees faced discipline twice as many times for off-duty conduct involving criminal activity, as compared to non-criminal activity. Courts referred to the teacher-as-role-model and nexus theories in $90 \%$ of the cases. 


\section{TABLE OF CONTENTS}

PAGE

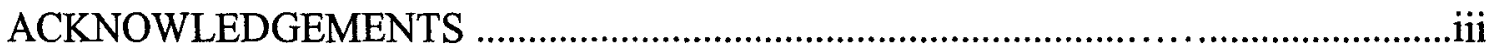

ABSTRACT …

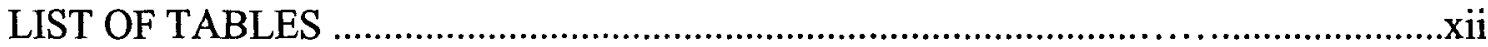

\section{CHAPTER}

I. NATURE AND BACKGROUND OF STUDY ...........................1

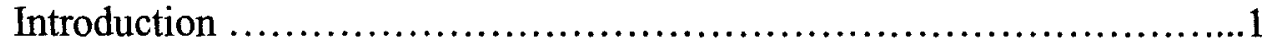

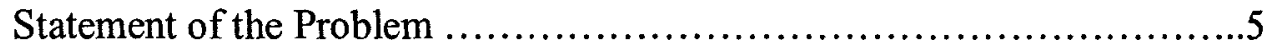

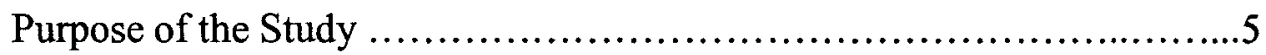

Research Question ................................................

Significance of the Study ..........................................

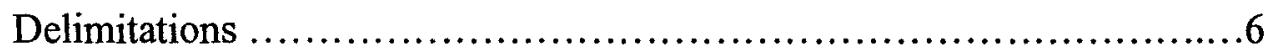

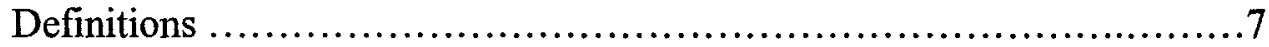

II. REVIEW OF THE LITERATURE .....................................

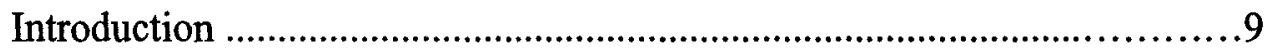

Private v. Public Life of P-12 Public School Employees ..................9

The Moral Purpose of Education .....................................11

P-12 Public School Employees and the Role Model Theory ................13

Albert Bandura and the Role Model Theory......................13

Historical View of Teachers as Role Models ......................15 
Antiquity .15

European Influences ...........................................

Colonial America .................................................

Nineteenth Century America ......................................21

Early Twentieth Century America $. . . \ldots \ldots \ldots \ldots \ldots \ldots \ldots \ldots \ldots \ldots . . .22$

Middle Twentieth Century America $. . . \ldots \ldots \ldots \ldots \ldots \ldots \ldots \ldots \ldots . \ldots \ldots$

Twenty-First Century ...........................................28

Significance of Teachers as Role Models ............................29

P-12 Public School Employees and the Nexus Theory ....................33

Private Sector ..................................................33

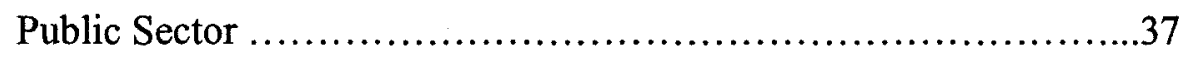

Nexus Applied to P-12 Public Education ............................39

The Debate in the Courts .......................................41

Constitutional Rights - Employee Challenges .........................45

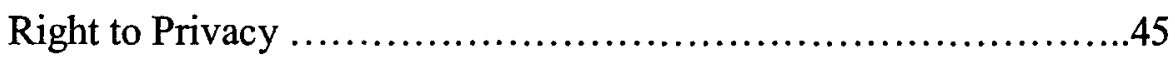

Freedom of Association .......................................46

Freedom of Speech ...........................................48

Freedom of Religion .........................................51

Right to Reputation ............................................52

The Due Process Clause ............................................54

Procedural Due Process of Law .................................55

Substantive Due Process of Law ...............................56

Equal Protection Under the Law ................................56 
Summary

III. METHODOLOGY …..................................................60

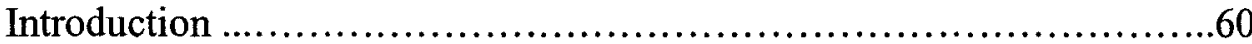

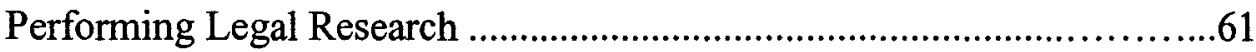

Identifying The Primary Sources .................................66

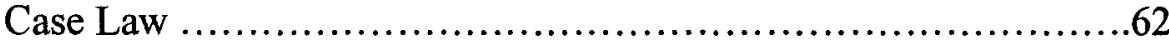

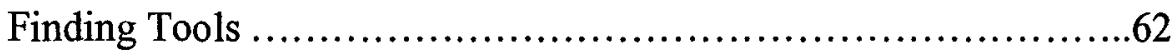

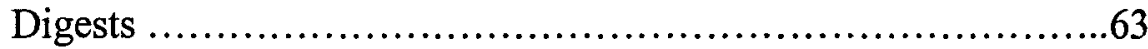

West Key Numbering System ....................................63

Headnotes ...................................................64

Descriptive Word Index ......................................64

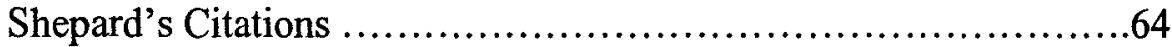

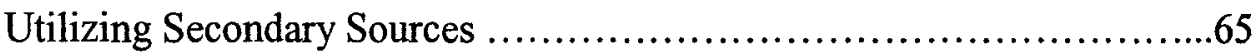

Periodicals and Books ............................................66

Encyclopedias ..................................................67

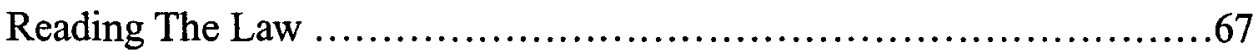

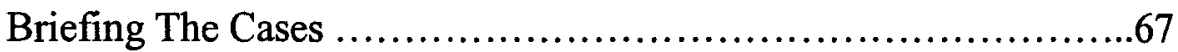

Key Elements from the Case Analysis Form ......................68

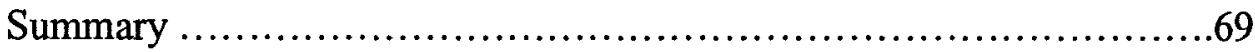

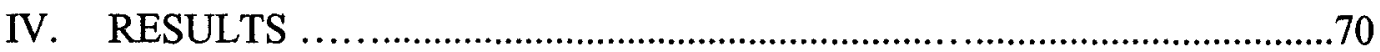

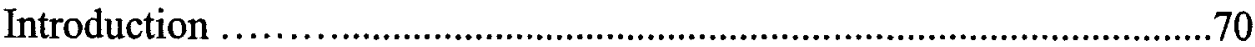

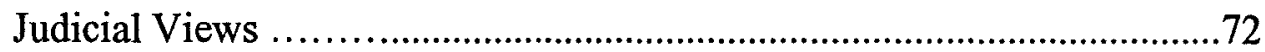

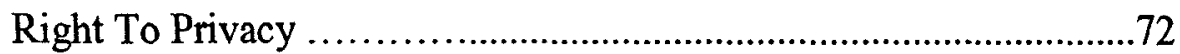




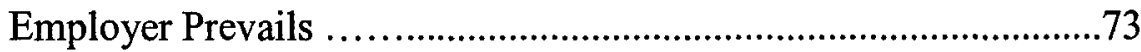

Employee Prevails ................................................

Freedom of Association ........................................... 88

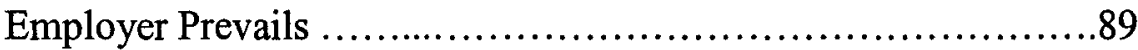

Employee Prevails ...........................................92

Freedom of Speech ........................................ 97

Employer Prevails ............................................... 98

Employee Prevails ...........................................104

Freedom of Religion .......................................... 108

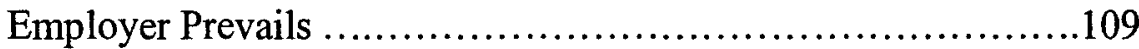

Right to Reputation ............................................. 110

Employer Prevails ......................................... 111

Employee Prevails .......................................... 116

Procedural Due Process ........................................ 119

Employer Prevails ........................................... 121

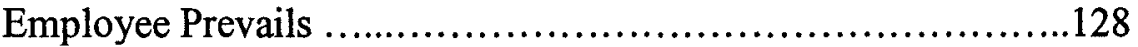

Substantive Due Process ...................................... 133

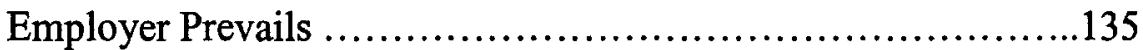

Employee Prevails ............................................143

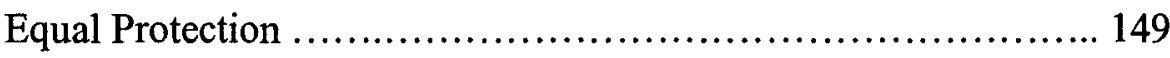

Employer Prevails ............................................. 150

Employee Prevails .........................................156

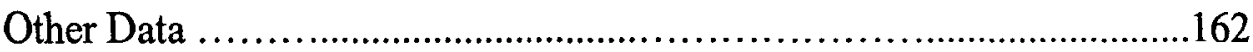


Judicial Use of Role Model and Nexus Theories .....................................163

Judicial Use of the Role Model Theory ......................................163

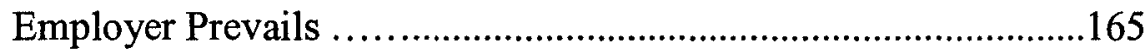

Employee Prevails ...................................... 171

Juridical Use of the Nexus Theory ..............................................175

Employer Prevails ...................................................................177

Employee Prevails ................................................183

Data Drawn From Collected Cases ................................... 190

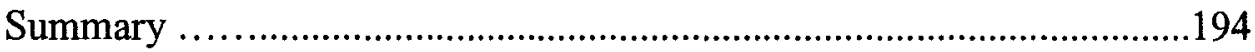

V. DISCUSSION, IMPLICATIONS, AND CONCLUSIONS …...................195

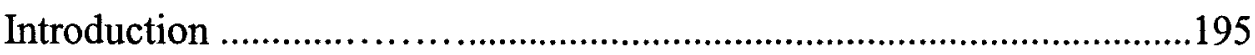

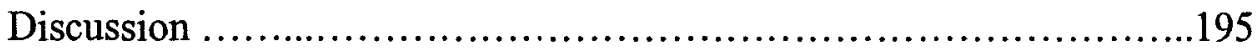

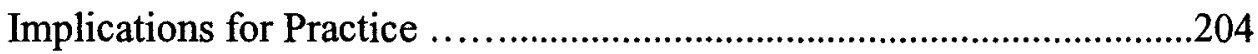

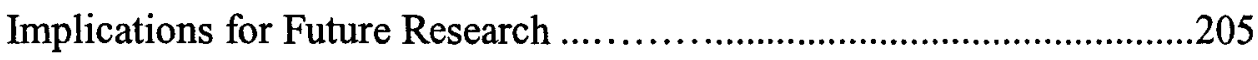

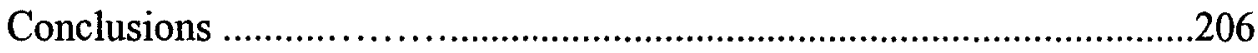

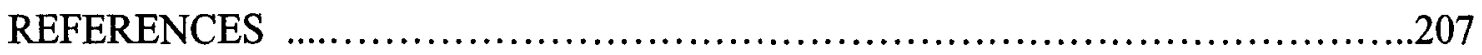

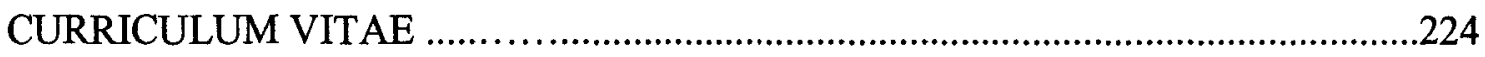




\section{LIST OF TABLES}

TABLE

PAGE

1. Legal Right Given Focus in Court Decision of All Identified Cases

by Decade

2. Types of Off-Duty Conduct Identified in the Case Law ........................71

3. Types of Off-Duty Conduct in Right to Privacy Cases by Prevailing Party .......72

4. Types of Odd-Duty Conduct in Freedom of Association Cases by Prevailing

Party

5. Type of Off-Duty Conduct in Freedom of Speech Cases by Prevailing

Party

6. Types of Off-duty Conduct in Right to Reputation Cases by Prevailing

Party

7. Types of Off-Duty Conduct in Right to Procedural Due Process Cases by

Prevailing Party

8. Types of Off-Duty Conduct in Right to Substantive Due Process Cases by

Prevailing Party.

9. Types of Off-duty Conduct in Right to Equal Protection Cases by

Prevailing Party

10. Judicial References to Role Model and Nexus Theories by Decade .163

11. Types of Off-Duty Conduct in Role Model Cases by Prevailing Party ..........164

12. Types of Off-Duty Conduct in Nexus Cases by Prevailing Party .176 
13. Prevailing Party in Cases Involving Criminal and Non-Criminal Off-Duty

Conduct 190

14. Employee Gender in the Off-Duty Cases ....................................190

15. Employee Positions Indicated in the Off-duty Cases .........................191

16. Cases by School Level ...................................................

17. Type of Off-Duty Conduct by School Level ................................192

18. Employee Loss Sustained and Prevailing Party ................................193

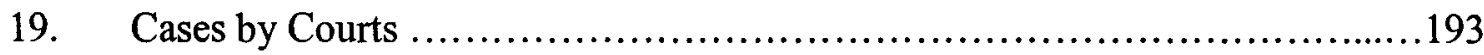

20. Prevailing Party by Hearing Level ........................................193

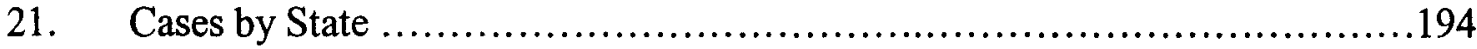




\section{CHAPTER I}

\section{NATURE AND BACKGROUND OF THE STUDY}

\section{$\underline{\text { Introduction }}$}

A wide array of personnel issues concern P-12 public school employers. Often these issues warrant discipline. The following scenarios are examples of disciplinary actions that public school employees challenged in the court system. An elementary school teacher with a satisfactory record in California lost her position after appearing on a television program discussing non-conventional sex. She and her husband belonged to a swinger's club. ${ }^{1}$ In Texas, the non-renewal of a contract for a high school principal occurred when the board speculated he suffered from a drinking problem. ${ }^{2}$ A non-tenured teacher with an excellent teaching record in Kentucky did not receive a new contact, when she separated from her husband and filed for divorce. ${ }^{3}$ In 1991, an unmarried teacher in Ohio did not receive a new contract after she became pregnant through an artificial insemination procedure. ${ }^{4}$

Into the late 1990's, off-duty conduct remained a basis for public school employee discipline. Concerned school officials declined to offer a contract to a Massachusetts elementary school teacher when concern arose about her living arrangements with a man facing various criminal charges, including a rape charge. ${ }^{5}$ Rumors regarding a teacher's

\footnotetext{
${ }^{1}$ See Pettitt v. State Bd. of Educ., 513 P.2d 889 (Cal. 1973).

${ }^{2}$ See Dennis v. S. \& S Consol. Rural High Sch. Dist., 577 F.2d 338 (5th Cir. 1978).

${ }^{3}$ See Littlejohn v. Rose, 768 F.2d 765 (6th Cir. 1985).

${ }^{4}$ See Cameron v. Bd. of Educ., 795 F. Supp. 228 (S.D. Ohio 1991).

${ }^{5}$ See LaSota v. Town of Topsfield, 979 F. Supp. 45 (D. Mass. 1997).
} 
homosexual lifestyle prevented his receiving a contract renewal in Ohio. ${ }^{6}$ A school board in West Virginia dismissed a teacher after he admitted to smoking marijuana in his home. $^{7}$ A school social worker in Connecticut received a dismissal notice after school officials discovered she was living with the father of several children who were her clients. ${ }^{8}$ Though the facts of these scenarios differ, they possess one commonality. While these activities occurred away from the workplace, they caused an adverse impact on the person's job. The chronology of the above scenarios, from 1973 through 2000, indicates the relevancy of off-duty conduct ${ }^{9}$ as an issue of concern for P-12 public school ${ }^{10}$ employees and employers into the twenty-first century.

While discipline of employees for on-the-job conduct is clearly a legitimate management right, the ability to discipline employees for off-duty conduct remains less clear. When it comes to the off-duty conduct of P-12 public school employees though, there is a strong precedent of involvement by employers and communities. Why has this been so? Scholars contend the concern for off-duty conduct relates directly to the moral purpose of teaching. ${ }^{11}$ Several noteworthy educational theorists throughout the twentieth century ascribed to a belief that education encompasses a moral purpose. Furthermore, educators demonstrate a view that the acquisition and development of morals is a

\footnotetext{
${ }^{6}$ See Glover v. Williamsburg Local Sch. Dist. Bd., 20 F. Supp.2d 1160 (S.D. Ohio 1998).

${ }^{7}$ See Woo v. Putnam County Bd. of Educ., 504 S.E.2d 644 (W. Va. 1998).

${ }^{8}$ See Kelly v. City of Meriden, 120 F. Supp. 2d 191 (D. Conn. 2000).

${ }^{9}$ For purposes of this study, off-duty conduct includes any activities and associations occurring away from the employer's premises and from any other place where employer business occurs.

${ }^{10}$ For purposes of this study, P-12 public school includes any primary, middle or high school established, maintained and regulated by state and local government.

${ }^{11}$ Much of the literature accessed for this study utilized the term "teacher" or "teaching." For purposes of this study, these terms represent any P-12 public school employee, including teachers, administrators and staff.
} 
legitimate and critical aim of the educational process. ${ }^{12}$ Hargreaves described excellent teaching as consisting of both technical skill and moral purpose. "Teaching is moral in that it contributes to the development of future generations." ${ }^{\text {13 }}$ One still might ask why this has any relation to what teachers do in their private lives.

Historically, communities hold teachers to a higher standard of conduct because they have a profound influence upon children. A teacher's participation in some questionable activity or lifestyle away from the schoolhouse raises concern within a community. "Since a unique relationship exists between the teacher and student, it becomes absolutely imperative that the character of the teacher stand above reproach."14 Communities expect teachers to conform to some accepted pattern of morality, though the definition of morality may differ from community to community. "The teacher encourages the community's children to be honest, sincere, courteous, and virtuous. When the teacher urges better living for the community, it is only fair for the community to expect the teacher to practice what he preaches."15

Beale indicated that a teacher's example in and out of school potentially influenced students more than what could be consciously taught. Beale further warned that a teacher's controversial off-duty conduct likely caused more trouble for the teacher than conduct in school. ${ }^{16}$ "The teacher's relations with the community may entail some of the most irksome restraints upon his freedoms." ${ }^{, 17}$ While Beale wrote in the earlier part of

\footnotetext{
${ }^{12}$ See JeAn PiAget, The Moral Judgment of THE ChILd (1965); See also Lawrence Kohlberg, Stages of Moral Development as a Basis for Moral Education, in C. M. BECK, ET AL., MORAL EDUCATION: INTERDISCIPLINARY APPROACHES 55 (1971).

${ }^{13}$ Adam Hargreaves, Development and Desire: A Postmodern Perspective, April 4, 1996, available at ERIC, ED372057.

${ }^{14}$ Robert A. Koenig, Teacher Immorality and Misconduct, 155 AM. SCH. BD. J. 15 (Jan. 1968).

${ }^{15}$ LESLIE TAYLOR, ET AL. THE AMERICAN SECONDARY SCHOOL 114 (1960).

${ }^{16}$ Howard K. BEALE, ARE AMERICAN TEACHERS FrEe 374 (1936).

${ }^{17}$ Id. at 388 .
} 
the twentieth century, the literature indicates society continues to set a high standard for teachers today. Teachers must be models for students. ${ }^{18}$ Often the term "role model" is ascribed to teachers. The "teacher as role model" theory recognizes teachers' responsibility in setting a good example for their students at all times. Alexander and Alexander pointed out that teachers must be of good moral character and their general reputation must attest to this fact. "Teachers must not only be moral persons, but must conduct themselves in such a manner that others will know of their virtue.,"19

Numerous cases heard in American courts relate to the off-duty conduct of P-12 public school employees. While employees dispute the right of public school employers to concern themselves with off-duty conduct, the employers argue the legitimacy of their concern. Often they rely on the role model theory when disciplining or dismissing employees for off-duty conduct. Employers cite terms such as "immoral" or "inappropriate" when considering off-duty conduct, especially when the conduct compromises a teacher's ability to role model within the classroom.

Courts often adopt similar terminology when deciding off-duty conduct cases. Also, judicial opinions often cite the teacher as role model theory and utilize terms such as "immoral" and "inappropriate" when referencing particular conduct or lifestyle. In 1969 , a case heard by the California Supreme Court set a new standard by which to determine the legality of school board and administrator involvement in the off-duty conduct of teachers. ${ }^{20}$ The court made use of the term "rational nexus" in the opinion to

\footnotetext{
${ }^{18}$ See C. Fallona, Manner in Teaching: A Study in Observing and Interpreting Teachers' Moral Virtues, 16 TEACHING \& TCHR. EdUC. 681, 693 (2000); See also Nel NoddINGS, CARING: A FEMININE APProACH to ETHICS AND MORAL EDUCATION 178-179 (1984).

${ }^{19}$ KeRn AleXANDER \& M. DAVID AleXANDER, AmERICAN Public SCHOOL LAW 574 (1992).

${ }^{20}$ See Morrison v. State Bd. of Educ., 461 P.2d 375 (Cal. 1969) (overturning dismissal of male high school teacher who had been dismissed when employer discovered he was homosexual and had one sexual encounter with a man).
} 
indicate that disciplining employees for off-duty conduct was only appropriate when that conduct rationally related to their job. ${ }^{21}$

\section{Statement of the Problem}

The problem is $\mathrm{P}-12$ public school employees continue to maintain private lives in conjunction with their professional lives. Some off-duty conduct may seem to warrant employer action, especially when the conduct is illegal, viewed as immoral, or simply questionable in the eyes of the community. The legal appropriateness of employer concern and involvement remains problematic when the concern and involvement relate to employee activities occurring entirely outside of the schoolhouse.

\section{Purpose of the Study}

The purpose of this study was to identify the legal contours of judicial responses to challenges related to adverse employment actions against $\mathrm{P}-12$ public school employees for off-duty conduct.

\section{Research Question}

The research question for this study is: When is it legal for $\mathrm{P}-12$ public school employers to discipline employees for off-duty conduct?

\section{Significance of the Study}

While some researchers explored the legal challenges brought by public school employees after being disciplined for off-duty conduct, these studies often include cases related to employee conduct on-the-job. ${ }^{22}$ Only one study identified dealt exclusively

\footnotetext{
${ }^{21} I d$ at 381 .

${ }^{22}$ See Margaret K. Allen, Legal Aspects of Teacher Dismissal for Immorality on Grounds of Sexual Misconduct (1990) (unpublished Ed.D. dissertation, University of North Carolina at Greensboro) (on file with author); See also Michael P. Benway, An Analysis of Higher Court Cases Relating to the Dismissal, Suspension, and Discipline of Public School Teachers on the Ground of Immorality (1976) (unpublished Ph.D. dissertation, Indiana State University) (on file with author).
} 
with off-duty conduct. ${ }^{23}$ While the study excluded cases involving on-the-job conduct, the study only examined sexual misconduct cases. An extensive search of scholarly educational literature and the Educational Resources Information Center database indicated the lack of a comprehensive study related to the research question.

Consequently, there is a void of relevant research related to the legal parameters involved in the discipline of public school employees for conduct occurring in their private lives. The need for a current and comprehensive study examining the legality of dismissal and other forms of discipline resulting from off-duty conduct exists. The significance of this study lies in the comprehensive approach to the relevant case law. While the study seeks to identify every case involving off-duty conduct of a public school employee, the study also seeks to examine cases involving a broad spectrum of off-duty conduct.

As litigation continues to occur, awareness of the legal issues involved in disciplining public school employees for off-duty conduct is critical for employers. This research provides information for public school employers to utilize in regard to policy development related to off-duty conduct of employees.

\section{Delimitations}

This study identified and analyzed reported cases of P-12 public school employees disciplined for conduct occurring off-duty. The specific limitations of this study are:

1. This study only addressed judicial challenges emerging from the P-12 public education sector.

\footnotetext{
${ }^{23}$ See Lawrence G. Mullins, Dismissal of Teachers for Out-Of-School Sexual Immorality Not Involving Students: Limitations and Guidelines regarding the Privacy Rights of Teachers (1995) (unpublished Ph.D. dissertation, Ohio State University) (on file with author).
} 
2. The study only analyzed cases stemming from off-duty conduct by P-12 public school employees. No analysis of cases clearly and directly involving employees' students, students in their schools, or students otherwise under their authority occurred. ${ }^{24}$

3. The study included court decisions reported prior to May 1, 2004.

There are limitations inherent to legal methodology. Only reported cases in the generally available legal literature were analyzed. Another limitation may be that the research overlooked a relevant court case. The use of a systematic approach to identifying cases minimized the potential for oversights.

\section{Definitions}

Typically dissertations include definitions detailing terminology specific to the topic. For this study, many of the definitions necessary to explain the legal concepts and terminology exist where relevant to the presentation of the material. This study used the following foundational definitions:

Moral Turpitude: "[S]hameful wickedness—so extreme a departure from ordinary standards of honest, good morals, justice, or ethics as to be shocking to the moral sense of the community; an act of baseness, vileness, or depravity contrary to the accepted and

\footnotetext{
${ }^{24}$ See e.g., Clark v. Ann Arbor Sch. Dist., 344 N.W.2d 48 (Mich. Ct. App. 1983) (upholding dismissal of tenured female teacher for inappropriate relationships with male student; Barcheski v. Bd. of Educ. of Grand Rapids Pub. Schs. 412 N.W.2d 296 (Mich. Ct. App. 1987) (upholding dismissal of tenured teacher after he invited students to party where they drank beer and smoked marijuana); Morris v. ClarksvilleMontgomery County Cons. Bd. of Educ., 867 S.W.2d 324 (Tenn. Ct. App. 1993) (upholding dismissal of tenured teacher who had sexual relations with student); Baltrip v. Norris, 23 S.W.3d 336 (Tenn. Ct. App. 2000) (upholding dismissal of tenured teacher charged with touching a student at his house); Andrews $v$. Independent Sch. Dist. No. 57, 12 P.3d 491 (Okla. Ct. App. 2000) (upholding termination of career teacher for engaging in a romantic relationship with a student, even though he claimed no sexual activity occurred); and Gover v. Stovall, 35 S.W.2d 24 (Ky. 1931) (upholding dismissal of male teacher for spending time in dark school building with three girls).
} 
customary rule of right and duty between people."25

Morality: "Conformity with recognized rules of correct conduct; [t]he character of being virtuous, esp. in sexual matters; [a] system of duties or ethics."26

Nexus: "A connection or link, often a causal one.",27

Unprofessional Conduct: "[I]mmoral, unethical, or dishonorable behavior either generally, or when judged by the standards of the actor's profession."28

${ }^{25} 50 \mathrm{Am}$. Jur. 2d Libel and Slander 165, at 454 (1995).

${ }^{26}$ BLACK's LAW DictionARY 1025 (7th ed. 1999).

${ }^{27}$ Id. at 1066.

${ }^{28}$ Id. at 292. 


\section{CHAPTER II \\ LITERATURE REVIEW \\ Introduction}

To analyze the judicial responses to cases related to off-duty conduct of P-12 public school employees, an understanding of employer and employee claims remains essential. Employers use two frameworks to defend their adverse employment decisions. One framework views teachers as role models. The other framework relies on the nexus theory. P-12 public school employees claim various constitutional rights when bringing suit against their employers. Employees frequently claim the following constitutional rights: privacy, freedom of association, freedom of speech, freedom of religion, reputation, procedural due process, substantive due process and equal protection of the law.

The purpose of this chapter is to examine the literature related to the role model and nexus theories along with the constitutional rights. An understanding of this literature provided the context for the analysis of the case law examined in the study.

\section{Private v. Public Life of P-12 Public School Employees}

While it is true that public school teachers are private citizens, much literature exists debating the amount of privacy afforded a teacher. "Historically, parents and school officials have maintained that a teacher cannot lead two lives - one as a role model in the school and another as a private citizen. It was assumed that one who chose a career in 
teaching surrendered a substantial measure of individual privacy."1 The private lives of teachers receive public scrutiny. Often teachers find themselves given a place in society comparable to ministers and their private lives become open like a "goldfish in a glass bowl." ${ }^{2}$ Many people believe teachers' professional lives are not separate from their private lives. "The professional self in teaching affects and is affected by personal history past and present." ${ }^{\text {"3 }}$ For instance, Bower documented that teachers' personal values affect the values they exhibit in the professional setting. ${ }^{4}$ Therefore, a teacher's personal values, exhibited through private actions, become a public matter. The private beliefs and values of the teacher potentially impact society's young within the classroom setting. ${ }^{5}$

The type of community in which the teacher works and resides frames a context for examining a teacher's private life. Historically, the public places more restrictions on teachers' conduct than the conduct of the average citizen. ${ }^{6}$ In 1927, Brubacher wrote the following statement regarding the personal conduct of teachers:

It is because of the place he holds in the community, as guide and preceptor of the very young, that the teacher must have high character. His obligations to the community can be paid only in terms of character. For his knowledge and skill have no value when divorced from the sound principles of conduct. In fact, character is the irreducible minimum of the teacher's equipment. It is part of the professional outfit that cannot be measured in tangible terms other than conduct. ${ }^{7}$

\footnotetext{
${ }^{1}$ Clifford P. Hooker, Terminating Teachers and Revoking Their Licensure for Conduct Beyond the Schoolhouse Gate, 96 EDUC. L. REP. 2 (1994).

${ }^{2}$ Willard S. ElSBREe, The AMERICAN TEACHER: Evolution of a Profession In A DEMOCRACY 296 (1939).

${ }^{3}$ Christopher Day \& Ruth Leitch, Teachers' and Teacher Educators' Lives: The Role of Emotion, 17 TEACHING \& TCHR. EDUC. 403, 414 (2001).

${ }^{4}$ William C. Bower, MoRAl AND SPIRITUAL VAlUES IN EdUCATION 88 (U. of Ky. Press, 1952); See also Howard K. BEALE, ARE AMERICAN TEACHERS FreE? 374 (1936).

${ }^{5}$ Bob Butroyd, Are the Values of Secondary School Teachers Really in Decline? 49(3) EDUC. REV. 251, 257 (1997).

${ }^{6}$ Bullock \& Faber, The Right of Privacy of Public School Employees, Feb. 9, 1989, available in ERIC, File No. ED303861.

${ }^{7}$ A. R. Brubacher, TEACHING: Profession ANd Practice 133-34 (1927).
} 
Even late in the twentieth century, many young teachers, particularly female, reported feelings of being watched in their communities. ${ }^{8}$ Society expects teachers to conform to certain community standards or mores. Because of societal expectations, teachers lived "on guard" so as not to violate community conscience. Koenig suggests that values and standards vary from community to community and teachers do well to apprise themselves of "the good conscience of the community in which he serves."

The conduct of a teacher warrants concern by the community. ${ }^{10}$ This is because many see education as a public function. The public funds education and expects education to meet its needs. "Teacher educators recognize that the ultimate control of education is justly and legally a public function." education exists and society allows it to survive. ${ }^{12}$ Societal expectations regarding who teaches children are equally important to what is taught and how it is taught. "The legal system has often supported the societal expectations that exist for public school teachers. Courts expect a teacher's conduct and character to be above reproach and to be above those of the average person not working in so sensitive a relationship as that of teacher and student. $^{13}$

\section{The Moral Purpose of Education}

An understanding of the theory that teachers are role models must be set in the context of the purposes of public education. The literature abundantly critiqued and debated the purpose of public education in America. There was no disagreement that a

\footnotetext{
${ }^{8}$ JOHN I. GOODLAD, A PLACE CALled SCHOOL 196 (1984).

${ }^{9}$ Robert A. Koenig, Teacher Immorality and Misconduct, AM. SCH. BOARD J., Jan. 1968, at 15, 16.

${ }^{10}$ Todd A. DeMitchell, Private Lives: Community Control v. Professional Autonomy, 78 EDUC. L. REP. 187 (1993).

"On The Role Of Teacher, 1967, available in ERIC, File No. ED022729.

${ }^{12}$ SIDNEY P. ROLLINS \& ADOLPH UNRUH, INTRODUCTION TO SECONDARY EDUCATION 2 (1964).

${ }^{13}$ E. Edmund Reutter JR. \& Robert R. Hamilton, The LAW of Public Education 593 (1985).
} 
past and present major purpose of education is training young people intellectually.

Additionally, a variety of scholars ascribed to the theory that education's purpose centers on producing good citizens who replicate the state as it stands. "Democracy has no other agent which serves to accomplish the educational tasks of cohesion and integration. The public school must be depended upon to teach those values that relate to us all."14

Many argued that education has another purpose, a distinctly moral purpose. "The aim of the schools was to teach the skills of reading, writing, and figuring, and to inculcate certain moral values and habits of discipline."15 One of the definitions for "education" offered in the Oxford English Dictionary is "to train any person so as to develop the intellectual and moral powers generally." ${ }^{\text {16 }}$ Furthermore, a definition of education includes the development of a mental and a moral discipline within a framework of universal and unchanging values. ${ }^{17}$ While much discussion occurred regarding what are truly universal values, continuing that debate does not occur here. The researcher relied on understanding that education possesses a moral purpose.

Thus it appears the clear mandate of the school (and the responsibility of the teacher) [is] that of making adequate provision for educative experiences through which basic values can be identified and understood. That the public school can do this both economically and consistently is the firm faith and practical philosophy of the educational profession. ${ }^{18}$

\footnotetext{
${ }^{14}$ Ellis HaRtford, MORAL Values IN PUBlic EduCation: LeSSONS From the KentuCKy EXPERIMENT 45 (1958); See also C. Buzzelli \& B. Johnston, Authority, Power, and Morality in Education, 17 TEACHING \& TCHR. EDUC. 873, 875 (2001). These authors indicated the purpose of education is to replicate the state of democracy.

${ }^{15}$ Paul WoOdring, A Fourth of a Nation 2 (1957); See also Howard K. BEale, A History of FREEDOM OF TEACHING IN AMERICAN SCHOOLS 207-208 (1941). Woodring and Beale indicated that the development of virtue and morality is a chief concern of schools and a major purpose of teaching.

${ }^{16}$ OXFORD ENGLISH DiCTIONARY (Judy Pearsall \& Bill Trumble eds., 1996).

${ }^{17}$ ROLLINS \& UNRUH, supra note 12 , at 1.

${ }^{18}$ HARTFORD, supra note 14 , at 61 .
} 
While some may argue that a moral purpose in education seems antiquated or old fashioned, recent educational scholars still ascribe to this belief. "We can properly conceive of education as a process that has to do with knowing, desiring, and doing good."19

The current research is not specifically about "moral education," otherwise referred to as "character education" or "values training." No attempt was made to define a specific curriculum dealing with morals that teachers transmit to students as education's purpose. This delineation is critical. "It appears that the current dialogue about education and morality extends beyond the consideration of specific curricula . . . ${ }^{20}$ Critical to the current research is an understanding of education as a moral enterprise in and of itself. Educational scholarship increasingly indicates that teaching is a moral enterprise. ${ }^{21}$

\section{P-12 Public School Employees and the Role Model Theory}

\section{Albert Bandura and the Role Model Theory}

The theory, function, and influence of "role modeling" received much attention within social and psychological literature, most notably by Albert Bandura. Role modeling may be thought of in a variety of ways: imitation, observational learning, internalization, copying, social facilitation, and role taking. ${ }^{22}$ Regardless of the term one uses, Bandura suggested that "much social learning is fostered through observing real life

\footnotetext{
${ }^{19}$ Kathleen M. Weigart, Moral Dimensions Of Peace Studies, in TEACHING FOR JUSTICE 12-13 (American Association of Higher Education ed., 1999); See also Gary D. Fernstermacher, Some Moral Considerations On Teaching As A Profession, in THE MORAL DIMENSIONS OF TEACHING 130-151 (John I. Goodlad ed., 1990).

${ }^{20}$ Pamela B. Joseph \& Sara Efron, Moral Choices/Moral Conflicts: Teachers' Self-Perceptions, 22(3) J. MORAL EDUC. 201 (1993).

${ }^{21}$ Id; See also Alan R. TOM, Teaching AS A Moral CRAFT 78 (1984); See also Gary D. Fernstermacher, Some Moral Considerations On Teaching As A Profession, in THE MORAL DIMENSIONS OF TEACHING 130151 (John I. Goodlad ed., 1990).

22 Albert Bandura, Psychological Modeling 3-4 (1971).
} 
models ... making role models a prevailing influence in the development of human behavior."23

Bandura placed his understanding of modeling within a social learning view, meaning that there is always a continuous interaction, reciprocal in nature, between the person and environment. "Social learning theory distinguishes between acquisition and performance because people do not enact everything they learn. They are more likely to adopt modeled behavior if it results in outcomes they value."24 If an observed behavior receives negative consequences, such as punishment, pursuit of that particular behavior may diminish. "Models do more than teach novel styles of thought and conduct.

Modeling influences can strengthen or weaken inhibitions over certain behavior ...,"25

Another point emphasized by Bandura centered on the type of person who is a role model and the perception a person holds of a role model. "Models who are high in prestige, power, intelligence, and competence are emulated to a considerable greater degree than models of subordinate standing." ${ }^{26}$ There are certain people in society who may be more effective role models due to their status or position.

Typically, the public viewed teachers as role models. "The public has typically held the view that the teacher should be an exemplar; that is, he should be a model for his students." ${ }^{27}$ While a primary purpose of teaching related to intellectual development, expectations that teaching involved role modeling remained strong. "In addition to teaching subject matter, students need to learn from someone they can perhaps look up

\footnotetext{
${ }^{23}$ Id. at 2.

${ }^{24}$ AlBERT BANDURA, SOCIAL LEARNING THEORY 29 (1977).

${ }^{25}$ Id. at 49.

${ }^{26}$ BANDURA, supra note 22, at 54-55.

${ }^{27}$ Bullock \& Faber, supra note 6; see also Mary M. Kennedy, Policy Issues In Teacher Education, 1989, available in ERIC, File No. ED326538; see also M. Chester Nolte, Establishing the Nexus: A School Board Primer, 38 EDUC. L. REP. 1, 3 (1987).
} 
to. ${ }^{28}$ The literature further indicated that a teacher often becomes somewhat of a hero to students. Students frequently admire and emulate a teacher and the student often becomes enthralled or even spiritually captured by them. ${ }^{29}$

Historical View of Teachers as Role Models

Antiquity

Historical precedent exists to support the idea of teachers as role models, particularly in regard to values, behavior, and conduct.

Since antiquity, the development of the moral or virtuous person has been a primary aim of education. It can be argued that this is even a prior purpose to intellectual or other forms of education. What a society wants to hand on, what it wants its young to learn are its ways of living, what it holds most valuable. It wants the young to accept and live by the values which society maintains. ${ }^{30}$

A variety of moral exemplars existed in antiquity. Miller indicated there were teachers like Socrates, Plato, and Aristotle, who many followed to guide their conduct and beliefs. "It is best to proceed inductively from the lives and judgments of moral exemplars to see what it is to be good."31

Socrates' dictum in The Apology emphasized the inextricable bind between education and virtue. "The greatest good for a man everyday [is] to discuss virtue ... life without inquiry is not worth living."32 Plato, influenced by Socrates, called for the conditioning or training of the young in such a way that they lead a virtuous life. "Because educators possessed correct standards of right and wrong, they were in Plato's

\footnotetext{
${ }^{28}$ Joseph J. Blase, Teachers' Perceptions of Moral Guidance, 56(9) CLEARINGHOUSE REV. 389 (1983).

${ }^{29}$ Gary S. Belkin, The Teacher as Hero, 22(4) EDUC. THEORY 411, 416 (1972).

${ }^{30}$ JOHN L. ElIAS, PHILOSOPHY OF EDUCATION: ClASSICAL AND CONTEMPORARY 41 (1995).

${ }^{31}$ Peter Miller, Who Are The Moral Experts?, 5(1) J. MORAL EDUC. 3 (1975).

${ }^{32}$ William H. D. Rouse, Great Dialogues of Plato 443 (1956).
} 
view justified in imposing standards on the young." ${ }^{\text {33 }}$ Morgan indicated that Plato addressed the concept of modeling as a critical part of training the young in his great work, The Republic. "Plato did not condemn imitation in and of itself; what he criticized, and indeed rejected, was imitation of inappropriate models. ${ }^{34}$ Plato, according to Morgan, believed imitation was a type of training that was an essential element of education. ${ }^{35}$

Aristotle believed a person was born without any character at all and the acquiring of a character was dependent solely upon one's upbringing. Excellence of character, therefore, was something parents and teachers passed on to children. Parents and teachers supplied both the intelligence and experience for children. Through practice and repetition of their thoughts and actions, one stood to gain an appropriate character. ${ }^{36}$ Adults, whether parent or teacher, model the things they wanted children to learn, for Aristotle believed in the habituation of excellence of character. ${ }^{37}$

Jesus Christ is another teacher considered a moral exemplar. The very purpose of His teaching was to model a way of life for people. Jesus said: "A student is not above his teacher nor a servant above his master. It is enough for the student to be like his teacher." ${ }^{, 38}$ At the Last Supper Jesus said to His disciples: "For I have set you an example, so that you might do just as I did to you." ${ }^{, 39}$ Jesus urged His followers to be like Him and follow His example.

\footnotetext{
${ }^{33} \mathrm{Id}$. at 43.

${ }^{34}$ Michael L. Morgan, Platonic Piety: Philosophy and Ritual IN Fourth-Century Athens 116 (1990).

${ }^{35}$ Id.

${ }^{36}$ J. O. URMSON, ARISTOTLE'S ETHICS 26 (1988).

${ }^{37} \mathrm{Id}$. at 25 .

${ }^{38}$ Matthew 10:24-25 (New International Version).

${ }^{39}$ John 13:15 (New International Version).
} 
The Apostle Paul, one of the New Testament writers, followed the teachings of Jesus. In his epistle to Titus, Paul wrote: "Urge the younger men as well to behave prudently and set in your own person an all around example of doing what is good, manifesting in your teaching integrity and seriousness. ${ }^{, 40}$ In essence, to teach with integrity one must be an example of goodness to those watching.

Persons achieve exemplar status because they believe in what they teach and they become an example for others to emulate. "No attitude, interest, or value can be taught except by the teacher who himself or herself believes in, cares for, or cherishes whatever it is that he or she holds out for emulation."

\section{European Influences}

In the 1530's John Calvin, a Swiss theologian, launched a religious movement and the doctrines he preached became the foundations for Puritanism in both England and colonial America. Puritanism espoused that children were born evil and possessed the motives to do evil. "Children are born evil and bound to sin if not guided away from their natural state. ${ }^{, 42}$ Furthermore, Puritans believed children were born without knowledge, yet they possessed a capacity to learn. ${ }^{43}$ Therefore, the role of education was critical to Puritan thought. Education was to redirect children from their natural inclination to sin, so they might be saved. The task of parents and teachers was the discovery of ways to dissuade children from this naturally evil bent. It followed that those assigned to this task, the parents and teachers, needed to be models for leading a good life. ${ }^{44}$

\footnotetext{
${ }^{40}$ Titus 2:6-7 (New International Version).

${ }^{41}$ Philip W. Jackson, The Practice of Teaching 124 (1986).

${ }^{42}$ R. MURRAY THOMAS, COMPARING THEORIES OF CHILD DEVELOPMENT 63 (2d ed. 1985).

${ }^{43} \mathrm{Id}$.

${ }^{44} I d$. at 54 .
} 
The British philosopher, John Locke, writing in the late seventeenth century promoted the theory of tabula rasa. He believed that a child's mind was a void or an unmarked page at birth. Experiences and interactions with others while growing to adulthood sketch the contents of the child's mind.$^{45}$ Locke's views emphasized the importance of environment on a child's development, particularly the role of others in the child's life. "Virtue is harder to be got than a knowledge of the world. The difficulty is that virtue cannot be taught ... [ [V]irtue must be instilled by custom, practice, and example. No ordinary tutor is equal to the task. ${ }^{„ 46}$

A philosopher from the eighteenth century, Rousseau, differed from Calvin, as he believed children were morally good at birth. He also differed from Locke in suggesting there was a predisposition toward good within a child and, therefore, the mind could not be a blank page at the beginning of life. While children were born with a moral predisposition, they act morally unless misled along the way. ${ }^{47}$ While the philosophies of Rousseau did not advocate specific positions on the role of teachers, it remains critical to understand his theories on child development because Rousseau's theories emphasized the critical role of education in the sustenance of a person's moral nature.

Literature related to the role of teachers in European culture during this time period indicated a strong emphasis upon the personal morality of teachers. Furthermore, a linkage existed between the task of conveying morality to the young and teaching positions. It was requisite for teachers to possess the usual characteristics of sound belief,

\footnotetext{
${ }^{45} \mathrm{Id}$. at 31 .

${ }^{46}$ JOHN W. YOLTON, JOHN LOCKE AND EDUCATION 31 (1971).

${ }^{47}$ ThOMAS, supra note 42 , at 54 .
} 
an honest life, and civility. ${ }^{48}$ There was the awareness that young people spent an abundant amount of time with their teachers. Therefore, the assumption was that teachers possessed influence over the development of a child's moral makeup. "Since a youngster might spend most of his waking hours for several years in the custody of the same instructor, it was imperative that the teachers be equipped to instill not only literacy, grammar, and manners, but also virtue and godliness. ${ }^{, 49}$ Older schoolteachers were often sought out and chosen above younger ones because "of the younger teachers' aptness to be more prone to lewd lust than the ancient man." ${ }^{, 50}$ Many scholars also note that schoolteachers held a very visible role within their communities and this social visibility required them to lead exemplary lives. Communities took a great deal of time in selecting their teachers to ensure they were of a suitable kind. ${ }^{51}$

\section{Colonial America}

Early American schools often faced difficulty in filling teaching positions.

"Communities had to take whom they could get for teachers, and colonial schoolmasters were often incompetent and careless in behavior." 52 Many of the people who became teachers in colonial America were indentured servants or criminals. Beale estimated that at least two thirds of teachers fell in these two categories. ${ }^{53}$ Yet, Beale noted that advertisements for teachers often included language such as "sober" and "moral" in describing the type of teacher that communities were seeking. Education had a moral

\footnotetext{
${ }^{48}$ JOHN MORGAN, GODLY LEARNING: PURITAN ATTITUDES TOWARD REASON, LEARNING, AND EDUCATION 205 (1986).

${ }^{49} I d$. at 206.

${ }^{50} \mathrm{Id}$.

${ }^{51}$ I. Pinchbeck, The State and the Child in Sixteenth Century England, 7 BRIT. J. SOC. 274 (1956); see also MORGAN, supra note 48 , at 215 . Authors indicated the high level of social visibility accorded to schoolteachers in their communities during this time period.

${ }^{52}$ Howard K. BEAlE, A History OF FREEDOM OF TEACHING IN AMERICAN SCHOOLS 10 (1941).

${ }^{53}$ Id. at 11.
} 
purpose, including the actual teaching of moral principles to children. Colonial schools tended to emphasize principles of morality as part of the curriculum, in addition to reading, writing, and arithmetic. ${ }^{54}$ Therefore, teachers needed to be upright and moral in their own life.

Most teachers resided and worked in small communities that controlled the teacher's life, both professionally and personally. ${ }^{55}$ In the attempt to fill teacher vacancies, many ministers in colonial communities also served as teachers. When there was both a teacher and a minister, the teacher reported directly to the minister. Imber indicated that teachers could not be employed in colonial America without the town minister approving their religious and moral rectitude. ${ }^{56}$ The minister, who controlled their teaching positions, scrutinized the lives of teachers. Ministers provided moral authority to their communities. Their control over the teacher naturally included strict adherence to certain moral standards. ${ }^{57}$ Harbeck noted that the personal deficiencies among schoolteachers during this time period often conflicted with those who hired and supervised them. Therefore, the development of intensive and restrictive regulation on teachers' personal conduct was inevitable. ${ }^{58}$

Standards of teacher certification and systems of inspection were nonexistent in the colonial American period; however, specific laws pertained to teachers and their conduct. Hobson indicated that teachers were required to possess certain abilities and moral character in order to be teachers. "If the abilities or moral character of the master or

\footnotetext{
${ }^{54}$ Elsie G. HobSON, EdUCATIONAL LEgislation AND AdMINISTRATION IN THE STATE OF NEW YORK FROM 177 TO 185017 (1918).

${ }^{55}$ Id. at 14.

${ }^{56}$ Michael Imber, Morality and Teacher Effectiveness, AM. SCH. BD. J., Apr 2001, at 64.

${ }^{57}$ Wilson Smith, The Teacher in Puritan Culture, 36 HARV. EDUC. REV. 394, 410 (1966).

${ }^{58}$ Karen Marie Harbeck, Personal Freedoms/Public Constraints: An Analysis Of The Controversy Over the Employment Of Homosexuals As School Teachers (1987) (unpublished Ph.D. dissertation, Stanford University) (on file with author).
} 
masters of any school are not such that they ought to be entrusted with the children or youth, they shall not be maintained." 59

\section{Nineteenth Century America}

The expectation during the nineteenth century was that teachers be models of purity within their communities. Teachers often felt pressure outside the schoolhouse in regard to their choice of religion, their speech, the way they dressed, the friends or company they kept, and their conduct in general. ${ }^{60}$ In 1841 , the annual report of the Boston Board of Education stated the "necessity for teachers to set examples for pupils in deportment, dress, conversation and all personal habits. ${ }^{, 61}$ Beale indicated some of the following personal habits of teachers garnered community attention: attending the theater, playing cards, drinking, dancing, and swearing. He further found restrictions on a teacher's activities that other citizens engaged in because of the belief that a teacher's conduct, even away from school, potentially had a great effect upon school children. ${ }^{62}$

Another element affecting teachers' private lives during this time period was that many teachers boarded with families in local communities. "The practice of local families taking turns boarding teachers in their homes allowed the community to monitor the private lives of teachers. ${ }^{\prime 63}$ The expectation was that teachers lead exemplary lives and model an appropriate lifestyle for their students.

The growth of the western United States during this century saw a number of women moving to frontier territories to serve as schoolteachers. Kaufman wrote that the majority

\footnotetext{
${ }^{59}$ HoBSON, supra note 54, at 28.

${ }^{60}$ JOEL J. SPRING, AMERICAN EDUCATION: AN INTROdUCTION TO SOCIAL AND POLITICAL ASPECTS 248 (1985).

${ }^{61}$ ELSBREE, supra note 2, at 296-297.

${ }^{62}$ HOWARD K. BEALE, ARE AMERICAN TEACHER's FreE? 374-375 (1936).

${ }^{63}$ John Trebilcock, Off Campus: School Board Control Over Teacher Conduct, 35 TULSA L.J. 445, $447-448$ (2000).
} 
of frontier schoolteachers were single, thus making them very vulnerable in regard to dealing with the opposite sex. "It was easy for a single woman's reputation to be damaged on the frontier. ${ }^{, 64}$ Frontier communities tended to be smaller making the schoolteacher highly visible to the people. Kaufman noted that communities expected their schoolteacher to be exemplary in character at all times. ${ }^{65}$

\section{Early Twentieth Century America}

The twentieth century brought a continued interest in the conduct of public school teachers. The general public continued to expect that teachers be models of purity within their communities. Whether a teacher was a good teacher connected directly to the teacher's personal ethics. ${ }^{66}$ There was a strong expectation that schoolteachers conform to certain community standards. Often community standards were more stringent for female teachers. ${ }^{67}$ For example, many communities refused to hire or keep a female teacher who chose to marry. "A woman teacher's marriage is equivalent to resignation in the majority of American school districts. ${ }^{~} 68$ Often this was because of the general belief that once a woman married, it was her husband's responsibility to take care of her and wrong for the husband to allow her to continue working. Other restrictions for female teachers included dyeing their hair, dancing, frequenting ice cream parlors, and going out after dark. ${ }^{69} \mathrm{La}$ Morte indicated that boards of education often enacted specific rules related to teacher conduct, such as teachers were not to travel beyond the city limits without permission

\footnotetext{
${ }^{64}$ Polly W. KaufMan, WOMEN TEACHers ON THE Frontier 37 (1984).

${ }^{65} \mathrm{Id}$. at 39.

${ }^{66}$ JOHN A. DAHL ET AL., STUDENT, SCHOOL AND SOCIETY 220 (1964). The term "purity" emerges in the early twentieth century educational literature in regards to teacher conduct. It was often used interchangeably with terms such as "high character," "moral," and "upright." See also BRUBACHER, supra note 7 , at 13 .

${ }^{67}$ Imber, supra note 56, at 64.

${ }^{68}$ Ervin E. Lewis, Personnel Problems of the Teaching Staff 173 (1925).

${ }^{69}$ Imber, supra note 56, at 64.
} 
from the board, teachers were not to dress in bright colors, a teacher's dress or skirt was to be a specific length, and a teacher was not to ride in a carriage or automobile with a man, unless that man was her father or brother. ${ }^{70}$

"Ideal schoolteachers had to withstand close scrutiny and exhibit flawless behavior in all aspects of their lives." ${ }^{, 71}$ In some ways schoolteachers gave up their lives when they took on their positions, as a way to please their community and meet the expectations set by the community. Joseph wrote, "[E]xcellent teachers and tactful teachers surrendered their own humanity for the sake of obliging the community." ${ }^{, 2}$ The societal expectations were extremely high regarding a teachers' conduct and there was a great deal of emphasis placed on teachers' character. Brubacher indicated that society judged teachers by their character primarily while their skills were of secondary concern. ${ }^{73}$

Much of the literature related to teachers as role models addressed the issue of teachers modeling morals. In this line of thought, teachers are often referred to as "moral agents." The term "moral agent" connotes the idea that teachers convey something about morality in everything they say or do. Many used this term to depict teachers who are specifically involved in the moral education of young people, while others used the term in a broader context. Teachers have a moral charge to be models of conduct, in the hope that their conduct exhibits necessary moral virtues for young people to live a good and happy life. ${ }^{74}$ The use of the term moral agent in referring to schoolteachers is traceable back as far as John Dewey. Dewey's writing in 1909 regarding teachers stated "[t]heir

\footnotetext{
${ }^{70}$ M. W. LAMORTE, SCHOOL LAW: CASES AND CONCEPTS 100 (1993).

${ }^{71}$ Pamela B. Joseph, The Ideal Teacher: Images in Early $20^{\text {th }}$ Century Teacher Education Textbooks, in IMAGES OF SCHOOLTEACHERS IN AMERICA 148 (Pamela B. Joseph \& Gail E. Burnaford eds., 2001).

${ }^{72}$ Id. at 147.

${ }^{73}$ BRUBACHER, supra note 7, at 133-134.

${ }^{74}$ Fallona, Manner In Teaching: A Study in Observing and Interpreting Teachers' Moral Virtues, 16 TEACHING \& TCHR. EDUC. 681, 693 (2000).
} 
actions, words, and so on carry a moral significance in themselves ... [ [t]eachers act as moral agents all the time, usually unconsciously."75

Dewey also advocated that the school had a duty to weed out what was undesirable in society and the school was the chief agency for this end. In Democracy and Education, Dewey wrote, "[I]t is the business of the school environment to eliminate, so far as possible, the unworthy features of the existing environment." ${ }^{, 76}$ It stands to reason that schools needed personnel modeling what was good and right about society. In fact, schools needed moral agents encouraging a better society in the future.

Other scholars echoed Dewey's philosophy and believed the aim of school was the elimination from society of that which was bad. Bode saw education as possessing a distinctive undertaking tied directly to the important values of life. The schools' job was to keep bad things away from young people and to encourage that which was good. ${ }^{77}$ While the development of young minds was a priority for schools, an equal and sometime more important priority was to develop good moral character in the young. Therefore, in the early twentieth century, it was more important for teachers to be moral and upright citizens than to be great scholars. ${ }^{78}$

Avent's text on teacher education indicated that teachers were to be moral exemplars within their communities. "The excellent teacher has much higher ideals than people in general." ${ }^{, 79}$ Furthermore, sometimes the expectation was that teachers have better personal traits than the parents of children they taught. "A teacher should be a public servant who serves the community through an upright, exemplary life and whose

\footnotetext{
75 JOHN DEWEY, MORAL PRINCIPLES IN EDUCATION 105 (1909).

${ }^{76}$ JOHN DEWEY, DEMOCRACY AND EDUCATION 45 (1916).

${ }^{77}$ BOYD H. BODE, FUNDAMENTALS OF EDUCATION 3-4 (1928).

${ }^{78}$ H. P. WRIGHT, THE Young MAN AND TEACHING 45 (1920).

${ }^{79}$ JOSEPH E. AVENT, THE EXCELLENT TEACHER 284 (1931).
} 
influence will give their children the characters they themselves failed to attain. ${ }^{, 80}$ Teachers were constantly under parental pressure in regard to their personal conduct. Beale indicated that while parents could smoke, swear, drink, and commit adultery, they hoped their children would not grow up to do the same. Parents expected teachers to model a cleaner and sober life, so that teachers molded their children with the virtues they lacked. $^{81}$

The reputation of the school held by the community concerned school leaders. The concern regarding teachers' personal conduct was a part of ensuring the good reputation of the school. "Teachers must make a good impression upon the community because unconventional conduct certainly arouses gossip and bringing unfavorable publicity to the school is a mortal offense. ${ }^{.82}$ Columbia Teacher's College defined morality as "conforming to the social mores, adapting to one's period, place, and people."

Frances Donovan, in her work The Schoolma'am, discussed a situation where four female schoolteachers rented a house in their community. This living arrangement of four unsupervised young women caused a great deal of suspicion, and the school board went so far as to pay local delivery boys to spy on the four single women in their home. ${ }^{84}$ Donovan indicated that schoolteachers were to be role models for the young. She further emphasized the expectation that many single, female teachers in small communities board with someone from the community as a means of controlling their conduct and revealing their personal habits. ${ }^{85}$

\footnotetext{
${ }^{80}$ BEALE, supra note 62 , at 407.

${ }^{81}$ Id.

${ }^{82}$ Id. at 391.

${ }^{83}$ DANiEl KulP, EduCATIONAL SOCIOLOGY 21 (1932).

${ }^{84}$ FRANCES R. DONOVAN, THE SCHOOLMA'AM 227 (1938).

${ }^{85}$ Id. at 226.
} 
Donovan viewed this intense societal interest and control over the teacher as part of being a teacher. "The schoolma'am is paid by the taxpayers. She is a public servant and the community claims the right to supervise her conduct and to demand that, like Caesar's wife, she be above suspicion. ${ }^{, 86}$ Beale cited the requirement that teachers sign contracts containing the following types of statements. "I promise to remember that I owe a duty to the townspeople who are paying my wages, that I owe respect to the school board and the superintendent that hired me, and that I shall consider myself at all times the willing servant of the school board and the townspeople . ..."87 A 1939 study examining teacher dismissals found most stemmed from personal rather than professional reasons. The study identified marriage and childbirth, immorality, rumors of immorality, and political activity as some of the reasons for dismissal. ${ }^{88}$

\section{Middle Twentieth Century America}

The literature indicated a slight shift in how society viewed its teachers after the war and into the 1950's. Calloway reported that seventy-five percent of teachers responding to a 1951 survey felt no pressure from their community in regard to card playing, dancing, and smoking. Yet many teachers responding to the survey indicated they felt pressure from their community in regards to social drinking and that social drinking was discouraged as a pastime. ${ }^{89}$ Teacher textbooks continued to emphasize that teachers were to be responsible to their community and the community set the standards. ${ }^{90}$ In the 1960 's

\footnotetext{
${ }^{86}$ Id. at 209.

${ }^{87}$ BEALE, supra note 62 , at 396 . The author was quoting language from a standard contract for North Carolina teachers in the 1930's.

${ }^{88}$ Anderson, Trends in Causes of Teacher Dismissal as Shown by American Court Decisions 9 (1939) (unpublished Ed.D. Diss., George Peabody College for Teachers).

${ }^{89}$ Byron Calloway, Are Teachers Under Community Pressure?, 37 SCH. AND CMTY. 458 (1951).

${ }^{90}$ Myron Lieberman, EduCATION AS A Profession 55 (1956).
} 
Bolmeier observed, "Teachers were more restricted than most citizens in the exercise of their freedom guaranteed by the Constitution."${ }^{.91}$

Many texts emphasized the special role of the teacher during this time period. An integral part of being a teacher was being a role model to the young. "The very vital and special role of the teacher in the education of the young places special demand upon him.... [S]uch demands enrich and enable the teacher's whole existence by urging him to live to the best standards he knows." ${ }^{92}$ Even recruiting materials for prospective teachers emphasized the need for teachers to be upright citizens. The National Education Association's pamphlet titled Invitation To Teaching emphasized that a teacher's role was assisting pupils in acquiring fundamental knowledge as well as wholesome attitudes and sound habits of thinking and acting. ${ }^{93} \mathrm{~A}$ teacher's preparation included being a good role model. Nolte stated, "[B]oards of education may legally expect the teacher to exhibit exemplary behavior and comply with local mores in dress and conduct, especially in public." $" 94$

The literature from the 1970's continued to emphasize the "teacher as role model" theory. One text by Dearden suggested that a person's ability to become self-controlled depended upon exposure to the good examples set by others. "In matters of morals, we learn first by being shown by others." ${ }^{95}$ During this same period, an alternative view emerged in the literature. Some scholars began addressing the privacy rights of teachers regarding their personal life away from school. Walden wrote, “[A] teacher's private

\footnotetext{
${ }^{91}$ Bolmeier, Legal Scope of Teachers Freedoms, EDUC. FORUM, 1960, at 199, 201; see also Harold H. Punke, Immorality as a Grounds for Teacher Dismissal, NASSP BULL., 1965, at 53.

${ }_{92}$ EARL V. PULlias \& JAMES D. YOUNG, A TEACHER IS MANY THINGS 74 (1968).

${ }^{93}$ Invitation To Teaching, in National Commission On Teacher Education And Professional Standards 5-7 (National Education Association of the United States, 1964).

${ }^{94}$ M. Chester Nolte, Teacher's Image, Conduct Important, AM. SCH. BD. J., 1967, at 29, 31.

${ }^{95}$ R. DEARDEN, ET AL., EDUCATION AND THE DEVELOPMENT OF REASON 46-47 (1975).
} 
behavior, as long as it remains private, is not subject to an employer's scrutiny." ${ }^{\prime 96}$ Davis advocated that teachers be able to do anything in their private life that an ordinary citizen could without fearing recrimination or judgment from their community. ${ }^{97}$

\section{Twenty-First Century}

Society continues to view teachers as role models and there exists ongoing interest in their conduct. ${ }^{98}$ In fact, many scholars believe it is most important to view the actions of teachers, rather than their words, to see what type of models they are for youth. "To find the core of a school, look at the way the people in it spend their time.... [L]ook for the contradictions between words and practice, with the fewer the better." ${ }^{.99}$ It remains critical to view a teacher's conduct at all times and not solely when he or she is on the job.

Relevant to these observations is the role a teacher has and the nature of his or her position as teacher. "The conduct of a teacher is evaluated on the basis of his or her position, rather than whether the conduct occurs within the classroom or beyond." ${ }^{100}$ It is vitally important that children and young people are around adults who have a value system that they appreciate. "Children and young people need to know that their parents and teachers have important values,"101 and their parents and teachers can act appropriately in varying situations. ${ }^{102}$

Some contemporary educators have ascribed to Dewey's belief that teachers are moral agents because " $[t]$ heir words and their actions carry great moral weight, teachers

\footnotetext{
${ }^{96}$ Walden, A Right to Privacy, NAT'L ElEMENTARY PRINCIPAL, 1974, at 99, 100.

${ }^{97}$ Davis, Teacher Dismissal on Grounds of Immorality, 46 CLEARING HouSE 422 (1972).

${ }^{98}$ Fallona, supra note 74, at 683; See also Imber, supra note 56, at 65.

99 THEODORE R. SIZER \& NANCY F. SIZER, THE STUDENTS ARE WATCHING 18 (1999); See also Belkin, supra note 16, at 418-419.

${ }^{100}$ Byrdena M. MacNeil, Disciplining the Off-Duty Teacher, EDUC. CAN. 2000, at 36, 36-37.

${ }^{101}$ Vito Perrone, A LetTer to TEACHERS: Reflections ON SCHOOLING AND THE ART OF TEACHING 7 (1991).

${ }^{102}$ Daniel Putman, The Primacy of Virtue in Children's Moral Development, 24(2) J. MoRAL Educ. 175, 182 (1995).
} 
unavoidably act as moral agents." ${ }^{103}$ Others insist that American schools and American society depend upon the moral agency of the individual teacher.

American society views the teacher as the agent and preserver of middle-class morality and expectations. Parents demand the teacher to be a better role model of behavior and conduct for their children than they are themselves. The teacher cannot fulfill their expectations unless he or she has convincing personal integrity. ${ }^{104}$

The literature indicates that Dewey's conception of teacher as a moral agent resurfaced in the 1980's as a growing emphasis on teacher values emerged. Along with this emphasis came much discussion about teachers being role models for students. ${ }^{105}$

Significance of Teachers as Role Models

An understanding of teacher authority as it comes with the teacher role is critical. In addition to influencing their students, teachers possess authority over their students. "The institutionalization of teaching provides both legal and community support for teacher authority." 106 Teachers hold authority over their students, making the relationship inherently unequal. "The basis of the teacher-student relationship is grounded in the inherent inequality of this relationship." ${ }^{107}$ Because of this unequal relationship, the student is a captive audience within the classroom. Authority gives teachers a level of

\footnotetext{
${ }^{103}$ Bill Johnston et al., The ESL Teacher as Moral Agent, 32(2) RES. TEACHING ENG. 161, 180 (1998); See also Jackson, supra note 41, at 264; See also Blasé, supra note 28, at 392.

${ }^{104}$ Hussein Fereshteh, The Nature of Teaching, Effective Instruction, and Roles to Play: A Social Foundations Perspective, CONTEMP. EDUC., 1996, at 73, 75; See also JOHN I. GOODLAD ET AL.., THE MORAL DIMENSIONS OF TEACHING 290 (1990). The authors indicated American schools depended upon teachers being moral agents.

${ }^{105}$ Trygeve Bergem, The Teacher As Moral Agent, 19(2) J. MoRAL Educ. 88 (1990).

${ }^{106}$ AlAN R. TOM, TEACHING AS A MORAL CRAFT 83 (1984).

${ }^{107}$ Id. at 80 .
} 
control over their students. "Children and youth grant authorities the right to formulate or to generate conventional as well as moral rules."108

Imber indicated that when parents and community members have concerns about a teacher's conduct, the real issue is whether the conduct has the potential to impact a teacher's ability to maintain authority in the classroom. ${ }^{109}$ When parents and school administrators disapprove of a teacher's off-duty behavior, they often fear children will not be able to learn from that teacher. ${ }^{110}$ Compromising a teacher's authority compromises his or her ability to manage the classroom. "Good classroom management is a condition for student learning."111

It is in this authority role that teachers do far more than teach curriculum. "Teaching involves a moral relationship between teacher and student that is grounded in the dominant power position of the teacher." $" 112$ Theodore and Nancy Sizer indicate the great extent to which students watch their teachers. "The students watch us all the time. We must honestly ponder what they see, and what we want them to learn from it." ${ }^{\text {"113 }}$ So how teachers teach, how they model, and what they model become extremely significant in this light.

To understand teachers as role models requires an understanding of the level of influence teachers possess. Henry Brooks Adams wrote that "[a] teacher affects eternity; he can never tell where his influence stops." ${ }^{\prime 14}$ A teacher is in contact with students on a daily basis for a minimum of nine months out of the year. An average teaching career

\footnotetext{
${ }^{108}$ Marie S. Tisak et al., Young Children's Conceptions of Authority in Context, 46(1) MERRILL-PALMER QUARTERLY, 168, 183 (2000).

${ }^{109}$ Imber, supra note 56 , at 66 .

${ }^{110} I d$.

111 JaCOB S. KoUnin, Discipline AND GROUP MANAGEMENT IN ClassRooms 100 (1970).

112 ToM, supra note 106 , at 78 .

${ }^{113}$ SIZER \& SIZER, supra note 99, at 121.

114 JOHN BARTLETT, FAMILIAR QUOTATIONS 535 (1992).
} 
affords a teacher the opportunity for personal contact with some twenty thousand young Americans. ${ }^{115}$ Some speculate that students spend more quality time with teachers than any other adult, including parents. "Teachers and students interact in close, complex social systems .... [S]chool is mandatory and teachers exercise considerable influence over their students by law, circumstance, and tradition."116

One form of influence that teachers have through role modeling is upon values' acquisition. ${ }^{117}$ It is inevitable that in the constant interchange between teachers and students and in the educational process in general, young people acquire, formulate, and modify their values. "Any legal obligation a teacher has to serve as an exemplar or role model for students rests on the belief that students, in part, acquire their social attitudes, values, and behaviors by copying those of their teacher." 118 Values can be defined as, "the internally organized and relatively consistent operating principles that serve as a guide for choice and action in individual life." 119 The teacher's role, therefore, is not solely related to intellectual development, but teachers influence the values of students they work with and also transmit their own values in the process. "This role modeling occurs in implicit and explicit ways and has the potential to be either a positive or a negative influence on the value development process of the student." 20

The role of the teacher also affects young people in the area of conduct and behavior. "Conduct is an important matter ... . [C]hildren do not heed much what the teacher tells

\footnotetext{
115 Leslie O. TAYLOR ET AL., THE AMERICAN SECONDARY SCHOOL 115-116 (1960).

${ }^{116}$ Christopher M. Clark, The Teacher and the Taught: Moral Transactions in the Classroom, in THE MORAL DIMENSIONS OF TEACHING, 251 (John I. Goodlad ed., 1990); see also Trebilcock, supra note 63, at 456.

${ }^{117}$ Neil J. Flinders, Values, Morality, and Religion in the School, 1991, available in ERIC, File No. ED356988.

${ }^{118}$ Hooker, supra note 1 , at 2.

${ }^{119}$ Carlton T. Mitchell, Values in Teaching and Professional Ethics 5 (1989).

${ }^{120}$ JOAN STEPHENSON ET AL., VALUES IN EDUCATION 166 (1998).
} 
them but are affected by imitation of what the teacher does." 121 Furthermore, children do not learn values or morality by learning maxims, but by being constantly influenced by a variety of people in their families and in institutions, such as school. Schools particularly are a place where children learn obvious standards of right conduct in regard to selfcontrol, fair dealing, and honesty. "Life is perfected by practice more than by precept; children are not taught so much as habituated."122

William Bennett indicated that for young people to take morality or values seriously, they must be around adults who take morality and values seriously. ${ }^{123}$ Young people possess the ability to detect hypocrisy. For instance, if a teacher says one thing yet does another, students become aware of the discrepancy. "Kids count on our consistency. Few qualities in adults annoy youth more than hypocrisy." 124 Students pick up messages that teachers send out, not only through their words but their actions as well. "Teachers' actions and teachers' conduct express or symbolize moral meanings."125

Perhaps this is why teachers sustain the level of trust that the public gives them. Lofty purpose and a sacred trust bound the profession of teaching. ${ }^{126}$ Society grants teachers authority over its young people and trusts that teachers utilize that authority in an appropriate manner. That manner includes activities both within and outside the classroom, for even actions as a private citizen may affect a teacher's role in the classroom. "Entrusted with the responsibility of instructing the young, they stand 'in

\footnotetext{
${ }^{121}$ BEALE, supra note 62 , at 407.

122 JAMES Q. WILSON, THE MORAL SENSE 249 (1993).

${ }^{123}$ WILLIAM BENNETT, THE BOOK OF VIRTUES 11 (1993).

${ }^{124}$ SIZER \& SIZER, supra note 99, at 11 ; see also JOAN F. GOODMAN ET AL., THE MORAL STAKE IN EDUCATION 159 (2001).

${ }^{125}$ David T. Hansen, From Role to Person: The Moral Layeredness Of Classroom Teaching, 30(4) AM. EDUC. RES. J. 651, 653 (Winter 1993).

${ }^{126}$ TAYLOR ET AL, supra note 115, at 105.
} 
Loco Parentis' before the law and the public and are expected to keep themselves above reproach.",127

The literature further indicated that the teacher's actions, behavior, and level of integrity represent the entire school. "Teachers and the integrity of their school systems remain inextricably linked. Teachers occupy positions of trust and confidence and exert considerable influence ... ," ${ }^{, 128}$ A teacher's actions may be indicative of what a school stands for or promotes. The integrity of an entire school system reflects in teachers' actions, both in and out of the classroom. Therefore, school administrators, boards, and the public at large maintain a vested interest in the activities of teaching personnel. "With respect to their conduct outside the classroom, teachers can expect to be held to a high standard due to the position of trust, confidence, and responsibility they hold in society." 129

\section{P-12 Public School Employees and the Nexus Theory}

Both public and private sector employers rely on the "nexus" theory when disciplining employees for off-duty conduct. A private sector employer, though, may terminate or otherwise discipline an employee for virtually no reason at all. Private sector employees possess no federal constitutional rights in terms of maintaining employment.

\section{Private Sector}

A critical examination of the private sector literature illuminates substantial concern regarding employees' private lives. ${ }^{130}$ While employers sustain the right to establish and enforce rules related to workplace conduct, the right of employers to require that

\footnotetext{
${ }^{127}$ ELSBREE, supra note 2, at 296.

${ }^{128}$ MacNeil, supra note 100 , at 36.

${ }^{129}$ Id. at 37.

${ }^{130}$ Michael Adams, Private Lives, SALES \& MARKETING MGMT., Sept. 1995, at S40, S42.
} 
employees maintain certain standards of conduct off the clock remains less clear. ${ }^{131}$

Historically, many organizations made it their business to know about employees' private lives. Early in the twentieth century large corporations employed departments designed to monitor the lives of company employees. Ford Motor Company employed one hundred investigators in their "sociological department" for the sole purpose of monitoring employees. They investigated employees' lives to evaluate everything from alcohol use to cleanliness, as well as to assess how employees spent leisure time. ${ }^{132}$ While companies today generally do not employ investigators to monitor the private lives of employees, employers often take an interest in the off-duty conduct of employees.

Off-duty conduct includes any activities that occur away from the employer's premises and other places employees conduct business. ${ }^{133}$ Off-duty conduct warranting managerial concern ranges from drug use and gambling to an employee's second job and personal relationships. For instance, there are numerous studies identifying relationships between employee drug use and job performance indicators such as absenteeism, accidents, turnover, worker's compensation claims, and medical insurance costs. ${ }^{134}$ Employers must be cognizant and aware of any employee conduct that affects business. "Given the risks inherent in doing business, it is not surprising that employers attempt to exert control over many factors external to the workplace, factors they believe might affect profitability." ${ }^{135}$ Alonso indicated that concerns regarding employees' private lives

\footnotetext{
${ }^{131}$ Rosalyn L. Wilcots, Employee Discipline for Off-Duty Conduct: Constitutional Challenges and the Public Policy Exception, 46 LAB. L.J. 3 (Jan. 1995).

${ }^{132}$ David F. Linowes \& Ray C. Spencer, Privacy: The Workplace Issue, 23 J. MARSHALL L. REV. 591, $597-$ 598 (1990).

${ }^{133}$ George D. Webster, Regulating Employees' Off-Duty Conduct, Ass'N MGMT., July 1992, at 99, 100.

${ }^{134}$ Wayne Lehman \& D. Dwayne Simpson, Employee Substance Use and On-The-Job Behaviors, 77(3) J. APPLIED PSYCHOL. 309 (1992).

${ }^{135}$ Arthur F. Silbergeld \& Stephanie T. Sasaki, The Right to Regulate Off-Duty Conduct, 27(2) EMP. REL. TODAY 101 (2000).
} 
primarily stem from the potential impact they have on the bottom line financials of an organization and further estimated employee problems stemming from their personal lives cost American businesses an excess of $\$ 150$ billion a year. ${ }^{136}$

While economic concerns motivate employers, other issues, such as moral considerations or avoidance of potential conflicts of interest, also motivate employers to take interest in the off-duty conduct of their employees. ${ }^{137}$ Some businesses, because of the nature of their work, maintain even higher levels of concern regarding employee conduct. Businesses in the healthcare field, for instance, have employees working directly with patients. Concerned with safety issues, businesses increasingly evaluate off-duty conduct as one measure of job performance. ${ }^{138}$

While employers advance a variety of reasons to maintain an interest in the off-duty conduct of their employees, employees argue any conduct off the clock is none of their employer's business. Private sector employees often insist their off-duty conduct or activities are unrelated to their jobs. Furthermore, any intrusion into their personal, offduty time potentially violates time-honored American values, such as privacy and freedom of association. Cozzetto and Pedeliski indicated, "However sacred these spheres of personal activity might appear, an employer might have interests which permit some limited intrusion." 139 Furthermore, "[o]ff-duty personal conduct may be regarded as relevant to employment if the misconduct has a nexus to the employee's performance within the organization or if the misconduct negatively impacts the organization's

\footnotetext{
${ }^{136}$ Mario Alonso, When an Employee Has Personal Problems, SUPERVISORY MGMT., at 3 (Apr. 1990).

${ }^{137}$ Janice L. Miller et al., Employer Restrictions on Employees' Legal Off-Duty Conduct, 44 LAB. L.J. 208, 218 (1993).

${ }^{138}$ Donna L. Mantel, Off-Duty Doesn't Mean Off the Hook, RN, Oct. 1999, at 71.

${ }^{139}$ Don A. Cozzetto \& Theodore B. Pedeliski, Privacy and the Workplace, 26(4) PUB. PERSONNEL MGMT. 515 (Winter 1997).
} 
mission." 140 The establishment of a "nexus" or link between the off-duty conduct and the employee's job is necessary.

Nexus assumes a variety of forms, including injury to a company's reputation or product, effect on an employee's ability to perform the functions of his or her job, or adverse impact on other employees or on the efficient operation of business. ${ }^{141}$ Nexus is the connecting link between an employee's job and the employee's off-duty conduct. ${ }^{142}$ No justification exists for the discipline of an employee for conduct or activities away from work unless a nexus is present. "When the employer can establish a logical, if not obvious, connection between the behavior and the job, it can often safely punish the person." ${ }^{143}$ Disciplinary actions, therefore, only occur against an employee when off-duty conduct is injurious to a legitimate interest of the organization. "The right of an employer to discipline employees is limited to conduct that adversely impacts the employer's operations."144

The literature identifies several issues that private sector employers must attend to when disciplining an employee for off-duty conduct. Alaniz suggests businesses and organizations maintain explicit policies addressing off-duty conduct. ${ }^{145}$ Written policies afford organizations the opportunity to provide notice to employees of rules and expectations regarding off-duty conduct. Potential for litigation emerging from disciplining an employee for off-duty conduct exist for private businesses. The literature suggests that written policies provide notice and offer organizations a basis of

\footnotetext{
${ }^{140} I d$.

${ }^{141}$ Robert A. Kearney, Arbitral Practice and Purpose in Employee Off-Duty Misconduct Cases, 69(1) NOTRE DAME L. REV. 135, 138-40 (1993); see also Wilcots, supra note 131, at 5.

${ }^{142}$ M. Chester Nolte, Establishing the Nexus: A School Board Primer, 38 ED. L. REP. 1, 3 (1987).

${ }^{143}$ Terry L. Leap, When Can You Fire for Off-Duty Conduct?, 66(1) HARV. Bus. REV. 28, 28-29 (1988); see also Wilcots, supra note 131, at 4.

144 Wilcots, supra note 131 , at 4.

${ }^{145}$ Richard Alaniz, Off-Duty Conduct: Make It a Company Policy, ElEC. LiGHT Power, Aug. 1990, at 58.
} 
consistency from which to discipline employees should the need arise. Terminations based on careful application of company policy communicated to employees and applied in an evenhanded manner can do much to help avoid litigation. ${ }^{146}$ The development and continual evaluation of uniform standards regulating off-duty conduct remains a critical business necessity. ${ }^{147}$

\section{Public Sector}

"Nexus" receives a similar definition relating to public sector employees as it receives in the private sector related literature. Off-duty conduct must negatively impact an employee's job performance or the efficient operation of the affected government agency to warrant discipline by the employer. ${ }^{148}$ In addition, courts have often considered whether a compelling state interest existed to warrant an employer's discipline or concern related to an employee's off-duty conduct. ${ }^{149}$ Higher standards applied to public servants, including teachers and other school personnel, than private sector employees. ${ }^{150}$ The mission or reputation of the agency receives stronger consideration when questioning a public employee's off-duty conduct. Furthermore, "nexus decisions are characterized by a declaration that certain jobs require a higher standard of conduct of employees than do other jobs." ${ }^{\prime 51}$ This higher standard application of nexus is more common with law

\footnotetext{
${ }^{146}$ Id. at 59; see also Miller et al., supra note 137, at 219.

${ }^{147}$ Terry M. Dworkin, It's My Life-Leave Me Alone: Off the Job Employee Associational Privacy Rights, 35 AM. BUS. L.J. 47, 66 (1997).

${ }_{148}$ Marvin J. Levine, Regulating the Off-Duty Conduct of Public Employees: Constitutional Issues, 14(4) J. Collective Negotiations 359, 372 (1985).

${ }^{149}$ Id.

${ }^{150}$ Michael Marmo, Public Employees: On-the-Job Discipline for Off-the-Job Behavior, ARB. J., 1985, at $3,15$.

${ }^{151}$ Neal Miller, Criminal Convictions, "Off-Duty" Misconduct, and Federal Employment: The Need for Better Definition of the Basis for Disciplinary Action, 39 AM. U. L. REV. 869, 887 (1990).
} 
enforcement officers. Occasionally, the standard applied to a person with a highly sensitive job position. ${ }^{152}$

The Civil Service Reform Act of $1978^{153}$ established procedures and guidelines governing discipline of federal employees. Prior to the Act, judicial review of cases related to employees' off-duty conduct varied. Vaskov indicated that courts simply required agencies to follow basic procedural requirements and rarely afforded employees any meaningful judicial review. As courts reviewed off-duty conduct cases, the reviews only included an examination of the factual record. ${ }^{154}$

The Civil Service Reform Act afforded courts a much broader scope for judicial review. The Act effectively balanced the interests of managers and employees by establishing minimal procedures that managers must follow in bringing adverse actions while providing employees greater protection for actions taken for off-duty, non-workrelated misconduct. ${ }^{155}$ The Act provided for disciplinary actions dealing with (1) unacceptable performance and (2) actions which a government agency may bring to promote the efficiency of service. ${ }^{156}$ Vaskov stated that "the Act clarifies both the basis of jurisdiction and the scope of review ... for off-duty, non-work related conduct."157

In essence, the Act requires the establishment of a nexus between off-duty conduct and one's job. Various factors accounted for the application of the nexus theory in disciplining an employee of government agencies. In addition to the obvious "workrelated effects, the Act provides agencies an additional opportunity to identify risk to

\footnotetext{
${ }^{152} \mathrm{Id}$.

${ }^{153}$ Civil Service Reform Act, 5 U.S.C. 1101 (1978).

${ }^{154}$ Stephen G. Vaskov, Judicial Review of Dismissal of Civil Service Employees for Off-Duty Misconduct: The Approach of the Federal Circuit, 34 AM. U. L. REV. 439, 440 (1985).

${ }^{155} I d$.

${ }^{156}$ Civil Service Reform Act, supra note 153.

${ }^{157}$ Vaskov, supra note 154, at 478.
} 
their work or reputation. ${ }^{158}$ The ability to provide expert testimony related to why the employee's off-duty conduct negatively affects the workplace is essential for government agencies. ${ }^{159}$ Experts can testify to the relationship between the conduct and the job duties. "More specifically, testimony as to the likelihood of work-related recidivism stems from the expert's close relationship with a specific individual." ${ }^{\text {"160 }}$ An expert is someone who knows the job and knows the individual. Occasionally a presumption of nexus may be established without the need for specific evidence of work-related effects to be produced by the employer. Truly egregious criminal behavior, such as sexual misconduct with a minor, automatically establishes nexus regardless of actual job impact. ${ }^{161}$

Nexus Applied to P-12 Public Education

The public education sector also utilized the concept of nexus. In order to discipline a public school employee for off-duty conduct "that act must somehow reduce the teacher's occupational effectiveness .... [T]here must be a connection ("nexus") between the act and the role of effective teacher." ${ }^{\text {162 }}$ However, exclusive application by the courts of the nexus theory to off-duty conduct cases did not exist. The traditional approach of the courts was to rely on the role model theory and to accept as a valid reason for dismissal any conduct, in or out of school, that set a bad example for students." ${ }^{163}$ In the 1970's an alternative rationale emerged as courts began to examine whether a relationship or a nexus between the teacher's conduct and the job existed. ${ }^{164}$ This shift began with the

\footnotetext{
${ }^{158}$ Miller, supra note 151 , at 885.

${ }^{159} I d$. at 908 .

${ }^{160} \mathrm{Id}$. at 909 .

${ }^{161} I d$. at 886.

${ }^{162}$ Bullock \& Faber, supra note 6, at 12.

${ }^{163}$ Floyd G. Delon, A Teacher's Sexual Involvement With Pupils: "Reasonable Cause" for Dismissal, 22 EDUC. L. REP. 1085 (1985).

${ }^{164}$ Id. at 1086.
} 
California Supreme Court's decision in Morrison v. State Board of Education discussed in detail below.

Furthermore, requiring a nexus to be established prevented board members from exercising their own moral judgments against teachers related to their private, off-duty conduct. Trebilcock suggested that protecting teachers from arbitrary dismissals concerned the courts. ${ }^{165}$ The use of the rational nexus theory provided objectivity to what was a purely subjective process largely dependent upon the community a teacher served and the morals subscribed to by community members. ${ }^{166}$ Imber's review of the education statutes of most states reveals that most states considered immorality, unprofessional conduct, or unfitness to teach as grounds for dismissal. ${ }^{167}$ While this type of language may seem to support school boards and communities imposing moral standards on teachers, the judicial standard most often requires the establishment of nexus.

Hill and Wright indicated that simply saying a nexus exists does not make it so. ${ }^{168}$ Administrators' ability to establish a nexus and do so objectively remains critical. Written policies outlining issues related to off-duty conduct or the ability to indicate, through documentation, how a teacher's specific conduct negatively impacted the job establishes nexus. "As the job in question becomes more public, ... the employer's burden in sustaining a discharge is easier than when the job does not involve dealing with the public." 169

\footnotetext{
${ }^{165}$ Trebilcock, supra note 63 , at 451.

${ }^{166}$ MARVIN F. HILl \& JAMES A. WRIGHT, EMPLOYEE LIFESTYLE AND OFF-DUTY CONDUCT REGULATION 258 (1993); see also Trebilcock, supra note 63, at 455.

${ }^{167}$ Imber, supra note 56, at 65.

${ }^{168}$ HILL \& WRIGHT, supra note 166, at 256.

${ }^{169} \mathrm{Id}$.
} 


\section{The Debate in the Courts}

One United States Supreme Court case set precedent regarding constitutional freedoms and public school personnel. In 1968, Pickering v. Board of Education ${ }^{170}$ established the concept of balance between the interests of an employee and the interests of the employer. Pickering was a public school teacher who wrote a letter to the editor of a local newspaper regarding his concern over the allocation of school funds. His concern centered on a recently passed tax increase, which Pickering believed benefited athletics over educational programs. As a result of the letter, the school board dismissed Pickering from his teaching position. Board members believed Pickering's letter contained false statements, causing harm to the professional reputation of school board members. They also believed the letter caused dissension among teachers, administrators, board members, and residents of the community. ${ }^{171}$

In Pickering, the Supreme Court considered several factors: (1) whether the speech criticized Pickering's superiors, (2) whether the speech criticized anyone with whom Pickering had daily contact, (3) whether the speech was a matter of public interest, (4) whether the statements were true or false, and (5) whether the speech impeded the proper performance of job duties. ${ }^{172}$ The Court referred to Pickering's concern as "an issue of general public interest." ${ }^{\text {173 }}$ The Court concluded that Pickering's interest as a citizen speaking on the matter of a tax increase outweighed the interest of the board in limiting his speech. The Court viewed Pickering's employment as "only tangentially and

\footnotetext{
${ }^{170}$ See 391 U.S. 563 (1968).

${ }^{171} \mathrm{Id}$. at 567.

${ }^{172} I d$. at 569-573.

${ }^{173} \mathrm{Id}$. at 571.
} 
insubstantially involved"174 and viewed Pickering's speech in his capacity as a citizen. Pickering's letter, therefore, enjoyed constitutional protection. The Court's decision in Pickering set a precedent for finding a balance between the interests of the employee and the interests of the employer. Case law related to off-duty conduct and public school employees since 1968 repeatedly cited Pickering. The ruling set forth a precedent that employees do enjoy constitutional freedoms as private citizens and those freedoms can outweigh the interests of their employers.

In 1969, the Supreme Court delivered another opinion regarding free speech in public schools. In Tinker v. Des Moines Independent Community School District, ${ }^{175}$ the plaintiffs included three students suspended for wearing black armbands to school. The students belonged to a group that publicly objected to the Vietnam War and the black armbands represented their objections. The school board adopted a policy requiring students to remove armbands or face suspension. The Supreme Court found for the students in this case. The wearing of armbands, while a passive and silent act, enjoyed full constitutional protection.

While the Court affirmed the right of schools to proscribe conduct within their walls so as to create an environment conducive for learning, the Court did not view the wearing of armbands as disruptive to the work of the school. School authorities possessed no rationale that the wearing of armbands would "materially" or "substantially" disrupt the work of the school. ${ }^{176}$ Without any potential for material or substantial disruption, Tinker's speech deserved protection.

\footnotetext{
${ }^{174} I d$ at 574 .

${ }^{175}$ See 393 U.S. 503 (1969).

${ }^{176} \mathrm{Id}$. at 508 .
} 
The suppression of the speech was therefore viewed as content based and the Court stated: "Our Constitution does not permit officials of the State to deny their form of expression." that was potentially controversial, as the school did not attempt to forbid the wearing of other armbands. "It can hardly be argued that either students or teachers shed their constitutional rights to freedom of speech or expression at the schoolhouse gate."178

On the heels of Pickering and Tinker, the California Supreme Court in 1969 adopted and applied the nexus theory in the landmark decision of Morrison v. State Board of Education. ${ }^{179}$ Morrison proved a watershed case regarding public school employees' right to privacy related to off-duty conduct and a major departure from the role model rationale. Morrison explicated a classic standard for nexus and "marked a change in the way many courts considered questions of teachers' off-duty conduct." ${ }^{180}$ Morrison was a teacher of exceptional children and possessed a good teaching record. Accusations of immoral and unprofessional conduct resulted from his friendship with an adult male. That friendship included one incident of homosexual activity. Morrison resigned his teaching position and the state board took the further step of revoking his teaching certificate.

The California Supreme Court listed a set of factors to consider when establishing a rational nexus between a teacher's off-duty conduct and a teacher's job. In determining the legality of the state board's decision to revoke Morrison's teaching certificate, the court considered the following factors:

1. The likelihood that conduct may have adversely affected students or fellow teachers;

\footnotetext{
${ }^{177}$ Id. at 514.

${ }^{178}$ Id. at 509.

${ }^{179}$ See 461 P.2d 375 (1969).

${ }^{180}$ L. FISHER \& DAVID SCHIMMEL, TEACHERS AND THE LAW 221 (1981).
} 
2. The degree of such adversity anticipated;

3. The proximity or remoteness in time of the conduct;

4. The type of teaching certificate held by the party involved;

5. The extenuating or aggravating circumstances, if any, surrounding the conduct;

6. The praiseworthiness or blameworthiness of the motives resulting in the conduct;

7. The likelihood of the recurrence of the questioned conduct; and

8. The extent to which disciplinary action may inflict an adverse impact or chilling effect upon the constitutional rights of the teacher involved or other teachers. ${ }^{181}$

On the basis of these factors the state board failed to establish to the court that there was a nexus between Morrison's activity and his teaching position. Therefore, the Court determined that the revocation decision was unwarranted. One of the cases the court cited in reaching the decision was Pickering. ${ }^{182}$ Chief Justice Tobriner stated in the majority opinion that "[w]here his professional achievement is unaffected, where the school community is placed in no jeopardy, his private acts are his own business and may not be the basis of discipline." ${ }^{\prime 183}$ Thus, a teacher's dismissal because he participated in off-duty conduct that was contrary to prevailing community beliefs was inappropriate.

The result in Morrison urged the judiciary to examine off-duty cases through the nexus framework. Yet, an issue of interpretation remains. When is it legal for $\mathrm{P}-12$ public school employers to discipline employees for off-duty conduct? The major concern of the courts is whether a teacher's private life interferes with his or her professional position.

\footnotetext{
${ }^{181} 461$ P.2d 375, 386 (1969).

${ }^{182}$ Id. at 391 . While the Morrison court relied on Pickering to reach its conclusion, the citation to Pickering is not verbatim. The Morrison opinion, citing Pickering, stated "[n]o person can be denied government employment because of factors unconnected with the responsibilities of that employment" The specific language from Pickering, though, that the California court was citing actually states "[w]hat we do have before us is a case in which a teacher has made erroneous public statements upon issues then currently the subject of public attention, which are critical of his ultimate employer but which are neither shown or can be presumed to have in any way either impeded the teacher's proper performance of his daily duties in the classroom or to have interfered with the regular operation of the schools generally" (Pickering, supra note 178, at 572-573). The Morrison decision broadly interpreted the Pickering outcome by applying it to the issue of "where" disputed conduct occurs. In Morrison's case it was while he was off-duty. The Pickering court never addressed "where" the disputed conduct took place. The Court's decision in Pickering only addressed "what" the conduct entailed and whether constitutional protection should be afforded. Whether or not Pickering wrote the letter on or off-duty was not an issue.

${ }^{183}$ Id. at 382.
} 
"The difficulty in establishing precise relationships between private actions and ability to teach allows for broad interpretation by different courts and school authorities." ${ }^{\text {184 }}$ While the nexus theory emerged as a viable standard to turn to in cases related to off-duty conduct, the philosophical standard of teacher as role model remains strong in American society. How often are judicial interpretations framed by the belief that teachers are indeed role models?

\section{Constitutional Rights - Employee Challenges}

\section{Right to Privacy}

Black's Law Dictionary defines the right of privacy as "[t]he right to personal autonomy." 185 Some rights considered basic to fundamental freedom are not specifically mentioned in the Constitution. "Among these is the right to personal privacy, which protects the individual from state interference." ${ }^{186}$ While the United States Constitution does not explicitly mention "privacy," numerous Supreme Court rulings affirm that the authors intended a right of privacy. Lewis claimed that "[t]o some extent, the entire Constitution and Bill of Rights express a right to privacy, that is, a set of limited and enumerated powers delegated to the government, with all other powers and rights held by the people." ${ }^{187}$ The Court has found the First, Ninth, and Fourteenth Amendments to support an individual right to privacy.

The courts often cited two secondary sources when deciding cases related to privacy rights. "The Right to Privacy," written by Warren and Brandeis in 1890, affirmed a

\footnotetext{
${ }^{184}$ SPRING, supra note 60, at 254; See also W. D. VALENTE, LAW IN THE SCHOOLS 214 (1987). This author indicated that courts before and after Morrison have remained divided on disciplining teachers for off-duty conduct. While nexus is an available standard, the issue of teacher as role model and exemplar remains strong regardless of proof of actual job impact.

${ }^{185}$ BLACK'S LAW DICTIONARY 1063 (7th ed. 2000).

${ }^{186}$ THOMAS T. LEWIS, THE BILL OF RIGHTS 940 (2002).

${ }^{187}$ Id. at 10.
} 
common law right of privacy. ${ }^{188}$ Prosser's article entitled "Privacy" was an additional secondary source providing contours to the concept of privacy. ${ }^{189}$ In this article, Prosser suggests several types of invasion to a person's privacy, including "intrusion upon the plaintiff's seclusion or solitude, or into his private affairs." 190

No case illustrates the right of privacy more so than the United States Supreme Court case, Griswold v. Connecticut. ${ }^{191}$ In the decision, the Supreme Court overturned a state law prohibiting the use of contraceptives. The majority opinion indicated that certain "zones of privacy" exist and emanate from the various guarantees within the Bill of Rights. ${ }^{192}$ The court viewed one such zone as the intimate relationship between a husband and a wife. Griswold v. Connecticut clearly defined privacy as a constitutionally protected right.

Understanding privacy remains critically tied to its legal context, either constitutional law or common law. In constitutional law, privacy entails the right an individual possesses to make certain fundamental decisions concerning personal matters and to do so free from government coercion, intimidation, and regulation. ${ }^{193}$ Under common law, privacy means the right to be let alone. ${ }^{194}$

\section{Freedom of Association}

Freedom of association encompasses "[t]he right to join with others in a common undertaking that would be lawful if pursued individually." ${ }^{195}$ Freedom of association guarantees persons the right to gather and to associate with anyone they choose. While

\footnotetext{
${ }^{188}$ Samuel D. Warren and Louis D. Brandeis, The Right to Privacy, 4 HARV. L. REV. 193 (1890).

${ }^{189}$ William L. Prosser, Privacy, 48 CAL. L. REV. 383 (1960).

${ }^{190}$ Id. at 389.

191381 U.S. 479 (1965).

${ }^{192}$ Id. at 484.

${ }^{193}$ WeST's ENCYCLOPEDIA OF AMERICAN LAW 166 (West Publishing Co. ed., 1998).

${ }^{194} \mathrm{Id}$.

${ }^{195}$ BLACK'S LAW DICTIONARY, supra note 185, at 532.
} 
the Constitution does not specifically mention freedom of association, courts have long recognized the right to associate for the purpose of engaging in the activities protected by the First Amendment: speech, assembly, petition for the redress of grievances, and the exercise of religion. Lewis wrote: "Freedom of association has been specifically inferred from the freedom of assembly clause within the First Amendment." 196

The Supreme Curt repeatedly supported the notion that freedom of association is a fundamental right enjoying constitutional protection. In $N A A C P$ v. Alabama ex. rel Patterson, the majority wrote: "The freedom to engage in association for the advancement of beliefs and ideas is an inseparable aspect of the liberty assured by the Due Process Clause of the Fourteenth Amendment, which embraces freedom of speech." ${ }^{, 197}$ Furthermore, the opinion stated: "Effective advocacy of both public and private points of view, particularly controversial ones, is undeniably enhanced by group association." 198

The Supreme Court, in Roberts v. United State Jaycees, understood freedom of association in two senses. The Court considered the freedom of intimate association and the freedom of expressive association. The freedom of intimate association entails the right of persons to enter into and maintain intimate human relations. "The constitutional shelter afforded such relationships reflects the realization that individuals draw much of their emotional enrichment from close ties with others." ${ }^{199}$ When writing their opinion, the Court emphasized family relationships, such as marriage, cohabitation with family members, creation and sustenance of family. "Family relationships, by their nature,

\footnotetext{
${ }^{196}$ LEWIS, supra note 186, at 123; See also EdWIN CHEMERINSKY, CONSTITUTIONAL LAW PRINCIPLES AND POLICIES 944 (1997).

197357 U.S. 449,460 (1958).

${ }^{198}$ Id. at 461.

${ }^{199}$ Roberts v. United States Jaycees, 468 U.S. 609, 619 (1984).
} 
involve deep attachments and commitments to the necessarily few other individuals with whom one shares distinctive personal aspects of one's life."200

The Court further discussed the right of expressive association. "We have long understood as implicit in the right to engage in activities protected by the First Amendment a corresponding right to associate with others in pursuit of a whole variety of political, social, economic, educational, religious, and cultural ends." ${ }^{201}$ The Court affirmed people's inherent right to choose whom they associate with for a variety of purposes and those associations enjoy constitutional protection. Justice O'Connor, in a concurring opinion, stated, "Protection of the association's right to define its membership derives from the recognition that the formation of an expressive association is the creation of a voice, and the selection of members is the definition of that voice."202

\section{Freedom of Speech}

Freedom of speech affords “the right to express one's thought and opinions without governmental restriction, as guaranteed by the First Amendment." ${ }^{203}$ Freedom of speech has received abundant scrutiny by the judiciary at all levels. Vile stated: "[F]ew freedoms are more essential to the democratic process than the freedom of speech, but acts of speech can be so related to action that the seemingly absolute prohibition in the First Amendment has been subject to numerous judicial qualifications."204

Freedom of speech is not limited to spoken and written words, but includes conduct "communicative in character." 205 Some of the various forms of judicially-identified

\footnotetext{
${ }^{200} \mathrm{Id}$. at 620.

${ }^{201} I d$. at 622 .

${ }^{202} \mathrm{Id}$. at 633.

${ }^{203}$ BLACK'S LAW DICTIONARY, supra note 185, at 533.

${ }^{204}$ JOHN R. VILE, ENCYCLOPEDIA OF CONSTITUTIONAL AMENDMENTS 134 (1996).

${ }^{205} 16$ A C.J.S. Constitutional Law $\S 502$.
} 
speech are as follows: pure speech, symbolic speech, pornography, and commercial speech. A continuum of speech exists based on the level of constitutional protection different types of speech enjoy. The continuum extends from pure speech, which enjoys complete constitutional protection, to unprotected speech (see Figure 1).

Figure 1. Illustrating the continuum of constitutional protection enjoyed by various types of speech.

\begin{tabular}{|c|c|c|c|c|}
\hline $\begin{array}{l}\text { Protected } \\
\text { Speech } \\
\text { (Pure Speech) }\end{array}$ & $\begin{array}{l}\text { Symbolic } \\
\text { Speech }\end{array}$ & $\begin{array}{l}\text { Commercial } \\
\text { Speech }\end{array}$ & Pornography & $\begin{array}{r}\text { Unprotected } \\
\text { Speech } \\
\text { (Obscenity, } \\
\text { Seditious Speech) }\end{array}$ \\
\hline & & & 1 & \\
\hline
\end{tabular}

Pure speech enjoys comprehensive protection under the First Amendment. Pure speech is speech that "simply and unobtrusively communicates an idea necessary to transmit the idea." ${ }^{206}$ Pure speech may or may not be popular but it is speech in the truest form intended to safeguard the exchange of ideas. Pure speech "extends to all subjects that affect ways of life, without limitation to any particular field of human interests, and includes freedom of expression on political, sociological, religious and economic subjects. ${ }^{207}$ Examples of pure speech include the public diatribes of Patrick Henry and Samuel Adams.

Symbolic speech includes "conduct that expresses opinions or thoughts. ${ }^{, 208}$ In order for symbolic speech to enjoy constitutional protection, the speech must represent a specific idea or viewpoint. ${ }^{209}$ Symbolic speech was the cornerstone of the plaintiffs'

\footnotetext{
${ }^{206}$ 16A C.J.S. Constitutional Law $§ 541$. See also BLACK's LAW DICTIONARY, supra note 185, at 1131 (defining pure speech as "words or conduct limited in form to what is necessary to convey the idea").

${ }^{207} 16$ A C.J.S. Constitutional Law $\S 541$.

${ }^{208}$ VILE, supra note 204, at 1132.

${ }^{209}$ Supra note 205.
} 
argument in Tinker. ${ }^{210}$ While the wearing of armbands was a silent and passive act, it was nevertheless an expression of opinion afforded constitutional protection. The majority opinion stated: "The prohibition of the silent, passive "witness of the armbands"... is no less offensive to the Constitutional guarantees."211

Courts afford less protection to commercial speech than to pure speech or symbolic speech because it involves communication, such as advertising or marketing. Commercial speech includes "expression related solely to the economic interests of the speaker and its audience."212 These interests are deemed of lesser importance than social, political, or religious speech, thereby enjoying less First Amendment protection. Government may also regulate or prohibit commercial speech that is false, deceptive, or misleading. ${ }^{213}$

Pornography enjoys some protection under the First Amendment and is defined as "material, such as writings, photographs, or movies, depicting sexual activity or erotic behavior." ${ }^{214}$ Pornography deemed legally obscene does not enjoy constitutional protection. This includes materials found "extremely offensive under contemporary community standards of morality and decency [which are] grossly repugnant to the generally accepted notions of what is appropriate. ${ }^{\text {215 }}$ Courts find pornography obscene when the material " . . taken as a whole, does not have serious literary, artistic, political, or scientific value."216

Freedom of speech was never intended to provide a license for illegal activity. "The guaranteed freedom of speech does not afford one the right to encourage and solicit

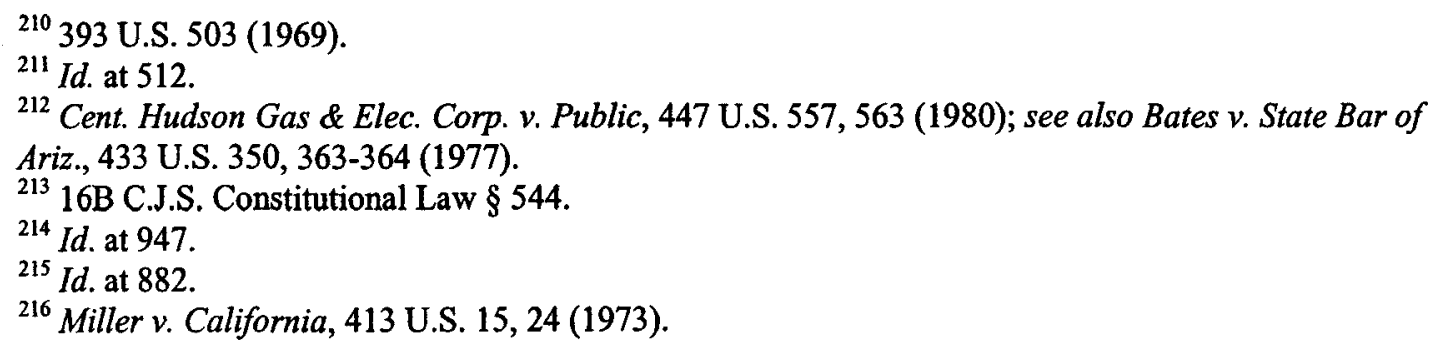


resistance to the execution of laws. ${ }^{217}$ Seditious speech, advocating law violation that directly incites or produces illegal actions or is likely to incite or produce such actions, does not enjoy constitutional protection. ${ }^{218}$

\section{Freedom of Religion}

Freedom of religion is defined as " $[\mathrm{t}]$ he right to adhere to any form of religion or none, to practice or abstain from practicing religious beliefs, and to be free from governmental interference with or promotion of religion, as guaranteed by the First Amendment." ${ }^{219}$ Any judicial review of freedom of religion claims considers two analyses, the Establishment Clause analysis and the Free Exercise analysis.

The basis of the Establishment Clause analysis rests on the First Amendment provision prohibiting government from creating or favoring a particular religion. ${ }^{220}$ The “old" Establishment Clause analysis asks: (1) does the law, policy, rule, or decision have a secular legislative purpose, (2) does its primary effect neither advance nor inhibit religion, and (3) does it result in excessive entanglement of government and religion. This analysis emerged from the Supreme Court's opinion in Lemon v. Kurtzman ${ }^{221}$ and is often referred to as the "Lemon test."

The Supreme Court's opinion in Lee v. Weisman ${ }^{222}$ provided the contours for the "new" Establishment Clause analysis. This analysis considers whether a government action created a government sponsored religious exercise. Secondly, the analysis

\footnotetext{
${ }^{217}$ 16A C.J.S. Constitutional Law $\S 546$.

${ }^{218}$ VILE, supra note 204, at 1138; see also BLACK's LAW DICTIONARY, supra note 185, at 1093.

${ }^{219}$ BLACK's LAW DICTIONARY, supra note 185, at 533.

${ }^{220}$ Id. at 449.

${ }^{221} 411$ U.S. 192 (1973). (The Supreme Court found excessive entanglement in a state statute providing a salary supplement to nonpublic school teachers who agreed not to teach courses in religion.) ${ }^{222} 505$ U.S. 577 (1992). (The United States Supreme Court held that "the inclusion of an invocation and benediction by a member of the clergy at a public secondary school graduation is forbidden by the establishment of religion clauses.")
} 
examines the issue of coercion and whether the government action resulted in coercing participants to be involved, directly or indirectly, in a religious exercise.

The Free Exercise analysis emerges from the constitutional provision prohibiting government from interfering in people's religious practices or forms of worship. ${ }^{223}$ Employment Division v. Smith ${ }^{224}$ offered the steps for courts to follow when considering free exercise claims. In this analysis, the plaintiff must prove a sincere religious belief and that the government action has placed a burden on their sincere religious belief. It is necessary for the plaintiff to combine this burden with some other constitutional right. The government must then prove a compelling interest existed. Additionally, that compelling government interest has two elements: the religious activity must be part of conduct which government has authority to regulate and the government's action must be generally applicable, meaning the action affects the religious belief incidentally. ${ }^{225}$

\section{Right to Reputation}

Black's Law dictionary defines reputation as "the esteem in which a person is held by others."226 Reputation is the public esteem or regard of an individual and illustrates the overall character of person in public opinion. The right to a good reputation is of ancient origin, though reputation alone is not specifically enumerated as a fundamental right of any one constitutional provision. ${ }^{227}$ From a constitutional perspective, the right to reputation argument involves a person's liberty interests. Liberty interests include

\footnotetext{
${ }^{223}$ BLACK'S LAW DICTIONARY, supra note 185 , at 533.

${ }^{224} 494$ U.S. 872 (1990). (The Supreme Court held that the state possessed a compelling interest to maintain existing drug laws. Furthermore, the free exercise clause permitted the state to include religiously inspired use of hallucinogenic drugs within the general criminal prohibition of the drug.)

${ }^{225}$ Id. (The Court found the government had a compelling interest in maintaining existing drug laws. Additionally, the government's drug laws were generally applicable, affecting plaintiffs' religious belief incidentally.)

${ }^{226}$ BLACK'S LAW DiCTIONARY, supra note 185, at 1047.

${ }^{227} 16$ A C.J.S. Constitutional Law $§ 511$.
} 
"interests protected by the due-process clause of state and federal constitutions." 228

Furthermore, liberty interests are those interests that remain free from "arbitrary or undue external restraint, especially by a government.",229

Various Supreme Court cases have considered the right to reputation. In 1971, the Court addressed the right of reputation when government action attached a "badge of infamy" to a person. ${ }^{230}$ Furthermore, the Court found damage to a person's liberty right when "a person's good name, reputation, honor, or integrity is at stake because of what the government is doing to him."231

In 1972, the Supreme Court rendered a decision that provided some limits related to right to reputation. While the Court agreed a "range of interests" exist that deserve constitutional protection, they argued the range was not infinite. ${ }^{232}$ Roth was a nontenured instructor who claimed that his contract nonrenewal harmed his professional reputation. The Court disagreed, pointing out that nonrenewal alone did not violate an instructor's liberty interest in reputation. "There is no suggestion that the State, in declining to re-employ the respondent, imposed on him a stigma." ${ }^{\text {233 }}$ Furthermore, the Court determined the actions of the State in no way limited Roth from future employment opportunities, as Roth remained free to seek other employment opportunities. ${ }^{234}$

In a 1976 decision, the Supreme Court gave further clarification to right to reputation arguments. The Court indicated that loss of reputation alone does not violate a person's liberty interests. Rather, reputation must combine with some other tangible interest, such

\footnotetext{
${ }^{228}$ BLACK'S LAW DICTIONARY, supra note 185 , at 743.

${ }^{229} \mathrm{Id}$.

${ }^{230}$ Wisonsin v. Constantineau, 400 U.S. 433, 434 (1971).

${ }^{231}$ Id. at 437.

${ }^{232}$ Bd. of Regents $v$. Roth, 408 U.S. 564, 570 (1972).

${ }^{233}$ Id. at 573.

${ }^{234} \mathrm{Id}$.
} 
as employment, to invoke procedural due process. "Mere defamation of an individual, whether by branding him disloyal or otherwise, is not enough. Defamation has to occur in the course of the termination of employment."235

\section{The Due Process Clause}

The concept of due process comes from English common law. There are two due process clauses within the Constitution. The creation of the Fifth Amendment clause limited the actions of the federal government, whereas the Fourteenth Amendment clause applied specifically to state and local governments. The Due Process Clause, requiring government proceedings to be fair, includes procedural and substantive process.

\section{Procedural Due Process of Law}

Procedural due process consists of "[t]he minimal requirements of notice and hearing guaranteed by the Due Process Clause of the Fifth and Fourteenth Amendments, especially if the deprivation of a life, liberty, or property interest may occur." ${ }^{236}$ The components of procedural due process protect individuals from government action in both criminal and civil spheres. A procedural claim "questions not the state's authority to impose the harm in question by an adequate decision process, but rather the adequacy of the process actually used."237

The due process clause affords procedural protections when a deprivation of life, liberty, or property occurs. If a deprivation occurred, then the courts determine what process is due the claimant. The key elements of procedural due process are notice and hearing. Notice arises in two ways. Notice can include notice of the charges and

\footnotetext{
${ }^{235}$ Paul v. Davis, 425 U.S. 985, 993 (1976).

${ }^{236}$ BLACK'S LAW DICTIONARY, supra note 185 , at 406.

${ }^{237}$ ENCYCLOPEDIA OF THE AMERICAN CONSTITUTION 2025 (Leonard W. Levy \& Kenneth L. Karst eds., 2000).
} 
processes for the hearing. ${ }^{238}$ Notice also relates to the "rules of the game." This includes knowing expectations, in terms of behavior, ahead of time so that the rules are understandable and not vague. ${ }^{239}$

In Board of Regents v. Roth ${ }^{240}$ the Court determined that a nontenured instructor possessed no property right to continued employment. Roth argued a loss of property when the Board failed to extend him a contract for the upcoming year. The Court found that Roth was entitled to nothing beyond the contract awarded for one year. Procedural due process only applied to the Roth's one-year teaching contract. As Roth was not terminated from his one-year contract but simply not extended a new contract, no deprivation of property occurred. "To have a property interest in a benefit, a person clearly must have more than an abstract need or desire for it. He must have more than a unilateral expectation of it. He must, instead, have a legitimate claim of entitlement to it."241 As Roth possessed no claim to continued employment, no entitlement to notice and hearing existed.

In another 1972 case, Perry v. Sindermann, ${ }^{242}$ the Supreme Court held that a nontenured college instructor deserved procedural due process when his contract was not renewed. In this case, the plaintiff argued that while his employer possessed no formal system of tenure, there was a system in practice that bestowed the equivalent of tenure upon certain employees. The Court agreed that often an unwritten "common law" creates a practice in a workplace. The plaintiff argued that this practice fostered his expectation

\footnotetext{
${ }^{238}$ See Matthews v. Eldridge, 424 U.S. 319 (1976).

${ }^{239}$ For purposes of this study, "rules of the game" was the only type of notice considered when an employee claimed procedural due process.

240408 U.S. 564 (1972).

${ }^{241}$ Id. at 577.

242408 U.S. 593 (1972).
} 
to continued employment. The Supreme Court determined the plaintiff deserved the opportunity of a hearing to prove the legitimacy of his claim of continued employment. ${ }^{243}$

\section{Substantive Due Process of Law}

The definition of substantive due process is " $[t]$ he doctrine that the Due Process Clauses of the Fifth and Fourteenth Amendments require legislation to be fair and reasonable in content and to further a legitimate governmental objective. ${ }^{244}$ Substantive due process concerns "what" government does or "why" government acts. It protects individuals from government actions that harm liberty or property rights. Substantive due process relates to the laws, polices, rules, regulations, and decisions of governments and whether these actions lie within their legal authority. Additionally, substantive due process examines the fairness of said laws, policies, rules, regulations, and decisions when applied. Substantive due process established limits on the government's power to interfere with individual liberty.

\section{Equal Protection Under the Law}

Equal protection under the law is " $[t]$ he constitutional guarantee under the Fourteenth Amendment that the government must treat a person or class of persons the same as it treats other persons or classes in like circumstances."245 The wording in the Fourteenth Amendment emphasized legal equality. In 1776, the founding fathers declared the "selfevident" truth of human equality when composing the Declaration of Independence. Yet, a succinct definition of "equality" remained unclear. For instance, when the Declaration of Independence was written, slavery existed as an integral part of America,

\footnotetext{
${ }^{243} I d$. at 603.

${ }^{244}$ BLACK'S LAW DiCTIONARY, supra note 185 , at 406.

${ }^{245}$ BLACK'S LAW DICTIONARY, supra note 185 , at 441.
} 
economically, politically, and socially. "From inception, then, a gulf has separated the Jeffersonian ideal of human equality from the reality of racial inequality."246

In order to consider an equal protection violation, the court must first determine if the government action intended to discriminate. Without intent to discriminate on the part of government, no equal protection violation occurs. If the government aimed to discriminate, the court must then determine if the government action burdens a suspect class or a fundamental right.

The Supreme Court has identified a suspect class as "one saddled with such disabilities, or subjected to such a history of purposeful unequal treatment, or relegated to such a position of political powerlessness as to command extraordinary protection from the majority political process." ${ }^{247}$ The three suspect classes are "race, national origin, or alienage." 248 Black's Law Dictionary defines a fundamental right as “a significant component of liberty, encroachments of which are rigorously tested by courts to ascertain the soundness of purported governmental justifications. ${ }^{\text {249 }}$ Fundamental rights are not always enumerated in the Constitution but are so designated by the Supreme Court. These rights are "rooted in the traditions and conscience of our people as to be ranked as fundamental." 250 They are the rights deemed "fundamental" to the creation and existence of this country.

If a suspect class or a fundamental right is burdened by the government action, the government must possess a compelling interest and no lesser alternative way to achieve

\footnotetext{
${ }^{246}$ Supra note 193, at 280.

${ }^{247} 16 \mathrm{~B}$ C.J.S. Constitutional Law $\S 714$.

${ }^{248}$ BLACK'S LAW DICTIONARY, supra note 185 , at 1174.

${ }^{249}$ BLACK'S LAW DICTIONARY, supra note 185 , at 541.

${ }^{250}$ See Snyder v. Massachusetts, 291 U.S. 97, 105 (1934); see also Griswold v. Connecticut, 381 U.S. 479, 486-487 (1965).
} 
the same interest. This analysis is referred to as the "upper tier" or the "strict scrutiny" test. "Equal protection analysis requires strict scrutiny of a legislative classification where the classification impermissibly interferes with the exercise of a fundamental right or operates to the peculiar disadvantage of a suspect class. ${ }^{\text {251 }}$ The fundamental rights giving rise to a strict scrutiny analysis include marriage, procreation, voting rights, certain aspects of criminal procedure, First Amendment rights, and the right to travel. ${ }^{252}$

When the government action causes no burden to a suspect class or a fundamental right, the Court turns to the "lower tier" or the "rational basis" test. This test involves the least amount of scrutiny. The test presumes the action of the government is legal and the government only needs a rational basis for its action. "The rational relationship test permits the legislature to employ any classification that is conceivably or arguably related to a government interest that does not infringe upon a specific constitutional right.",253

A "middle tier" or "intermediate scrutiny" test exists to resolve certain equal protection challenges. When a "quasi-suspect" classification is burdened by a government action, the Court utilizes the intermediate scrutiny test. A quasi- suspect classification often involves a statutory classification based on gender. ${ }^{254}$ This analysis examines whether government possessed a substantial interest and further determines if government actions are substantially related to achieving the same interest. "A classification is validated if it is reasonable and premised on some ground of difference

${ }^{251}$ BLACK'S LAW DICTIONARY, supra note 185, at 253.

${ }^{252} I d$.

${ }^{253}$ Supra note 193, at 284.

${ }^{254}$ BLACK's LAW DICTIONARY, supra note 185, at 1174. 
having a fair and substantial relationship to important government objectives so that all persons similarly situated are treated alike."255

While gender-based classifications are not considered suspect, such classifications often receive scrutiny by the courts. A variety of Supreme Court cases have scrutinized gender-based classifications. In Califano v. Webster ${ }^{256}$ the Court determined that the government possessed a substantial interest in promoting equal employment opportunities for women. The Court indicated classifications based on gender often afforded equal employment opportunities for women and compensated women for economic disabilities previously suffered. ${ }^{257}$ The Court, though, declared that when gender-based classifications create or further the "legal, social, and economic inferiority of women," those classifications would not survive the standard of review by the Court. ${ }^{258}$

\section{$\underline{\text { Summary }}$}

A review of the literature indicates that $\mathrm{P}-12$ public school employers apply the role model and nexus theories relative to adverse employment decisions based on off-duty conduct. Employees respond with various claims of violations of their constitutional rights. The role model and nexus theories along with the claimed constitutional rights provide the parameters used to examine the case law related to the research question: When is it legal for P-12 public school employers to discipline employees for off-duty conduct?

\footnotetext{
${ }^{255} 16 \mathrm{~B}$ C.J.S. Constitutional Law $\S 715$.

${ }^{256}$ See 430 U.S. 313 (1977); See also U.S. v. Morrison, 529 U.S. 598 (2000).

${ }^{257}$ See Califano v. Webster, 430 U.S. 313 (1977).

${ }^{258}$ U.S. v. Virginia, 418 U.S. 515,524 (1996).
} 


\section{CHAPTER III \\ METHODOLOGY}

\section{$\underline{\text { Introduction }}$}

Legal research is not qualitative or quantitative. Rather, legal research involves an interpretation and explanation of the law. Legal research is a systematic inquiry that is historical in nature. ${ }^{1}$ Yet, a definition that only addresses the historical nature is incomplete. Legal research leads to the discovery and examination of laws that govern our daily activities. Therefore, legal research affords a present day context for understanding the law. Furthermore, Cohen and Olson indicated that legal research provides valuable information needed to calculate future court action. ${ }^{2}$ Legal research utilizes a time line that scrutinizes the past and the present, and speculates about the future. Legal research is not linear but circular and somewhat overlapping. Legal analysis employs analytical, historical, and descriptive research methods.

Russo indicated that the roots of traditional legal research are the historical nature of the law and the law's reliance on precedent. ${ }^{3}$ The doctrine of stare decisis, meaning let the decision stand, remains fundamental to the American common law system. Stare Decisis is "[t]he doctrine of precedent, under which it is necessary for a court to follow

\footnotetext{
${ }^{1}$ Charles J. Russo, Legal Research: The "Traditional" Method, in RESEARCH THAT MAKES A DIFFERENCE: COMPLIMENTARY METHODS FOR EXAMINING LEGAL ISSUES IN EDUCATION 34 (David Schimmel ed., 1996).

${ }^{2}$ Morris L. COHEN \& Kent C. Olson, Legal ResearCh IN A Nutshell 1 (1996).

${ }^{3}$ Russo, supra note 1 , at 35 .
} 
previous judicial decisions, when the same points arise again in litigation."4

Understanding the American legal system's inherent reliance on precedent was crucial for the researcher. Legal research demands an examination of past cases to identify authoritative law that governs the question under investigation. Case law is a system where previous decisions bind and affect the outcome of later decisions within a jurisdiction. ${ }^{5}$

\section{Performing Legal Research}

The research for this study occurred at the Brandeis Law Library of the University of Louisville. The researcher also accessed a variety of sources related to the topic at the Ekstrom Library of the University of Louisville. The researcher utilized print resources and electronic resources to gather data. Westlaw and LEXIS NEXIS are two of the most comprehensive electronic resources for legal research.

This dissertation adheres to the Guidelines for the Preparation and Processing of Dissertations ${ }^{6}$ prepared by the Graduate School of the University of Louisville. The researcher utilized The Bluebook ${ }^{7}$ as a reference for citing all cases, periodicals, books, and other documents accessed during the course of the research. The researcher also utilized The Redbook: A Manual on Legal Style ${ }^{8}$ to gain additional information related to legal writing.

\footnotetext{
${ }^{4}$ BLACK'S LAW DictionaRY 1137 (7th ed. 1999).

${ }^{5}$ THOMAS T. LEWIS, THE BILL OF RIGHTS 13 (2002).

${ }^{6}$ University of Louisville (Jan. 28, 2003).

7THE BLUEBOOK: A UNIFORM SYSTEM OF CITATION (Columbia Law Review Ass'n et al. eds., 17th ed. 2000).

${ }^{8}$ Bryan A. Garner, The RedboOK: A Manual ON Legal Style (2002).
} 


\section{Identifying Primary Sources}

Primary sources define the law and are authoritative. ${ }^{9}$ Case law was the only primary source used for this study. Case law remains one of the most significant sources of legal authority within the American common law system. ${ }^{10}$ Case law reveals an evolving body of judicial decisions the courts deliver. Judicial decisions include the decision of who won and the remedy granted. Furthermore, a judicial decision provides the "reasoned explanation" by the judge in making the decision. ${ }^{11}$

\section{Case Law}

A primary objective of this research project was to locate all reported cases germane to the research question. In order to identify relevant case law, the researcher assessed cases in light of the research question. The researcher concluded a case was "on-point" when the case involved a P-12 public school employee who received discipline as a result of off-duty conduct. Cohen and Olson indicated that a critical part of understanding the applicable law for a given set of facts was the ability to locate on-point cases. ${ }^{12}$ Since chronology rather than topic establishes the arrangement of published case law, the researcher accessed a variety of finding tools to locate on point cases.

\section{Finding Tools}

A variety of finding tools exist to facilitate legal research. Finding tools give subject access to case law. "Finding tools are only a means for locating primary sources. Those

\footnotetext{
${ }^{9}$ Christopher G. Wren \& Jill R. WREN, The Legal Research Manual 41 (1984).

${ }^{10}$ COHEN \& OLSON, supra note 2, at 17.

${ }^{11}$ LEWIS, supra note 5, at 13.

${ }^{12}$ COHEN \& OlsON, supra note 2 , at 49.
} 
sources must then be read to determine their applicability." ${ }^{13}$ The following paragraphs introduce the various finding tools employed throughout the course of this research.

\section{Digests}

Digests compile major points of law in judicial opinions. The digests provide relatively easy access to a subject or particular question, as they contain headnote summaries of the points of law from each case listed. The digests publish the summaries alphabetically by topic, with numerous subdivisions falling under each topic. West Publishing Company publishes the most comprehensive digest system. ${ }^{14}$ West's digest uses a key numbering system "based on a comprehensive classification of American legal doctrine and covering every case published in West's National Reporter System."15 The key numbers consist of a classification of every American legal doctrine and cover every case published in West's National Reporting System. The researcher accessed West's digest system repeatedly during the course of the study.

West Key Number System. The key number system contains more than four hundred numbered and keyed topics. Each topic divided into manageable units or numbered sections containing specific points of law. These numbered sections are the actual key numbers. Subject access to cases, regardless of jurisdiction, is a prime benefit of the key numbering system.

Key numbers lead to applicable abstracts and case citations. The researcher utilized the following key numbers during the study: Schools (47), (132), (137), (147); School Districts (132), (133), (141); Federal Court (776); Constitutional Law (90), (211), (213), (215), (224), (242), (255), (278); and Civil Rights (164), (206), (242), (378), (453).

\footnotetext{
${ }^{13} \mathrm{Id}$. at 6.

${ }^{14} I d$. at 51 .

${ }^{15}$ Id.
} 
Headnotes. All case entries published in the National Reporter System become entries in West's digest. Before a case enters the digest, a short synopsis appears, otherwise known as a headnote, including any significant point of law addressed in the case. West then classifies the headnote by topic and, further, by key number. Headnotes are alphabetical, arranged by topics and organized in numerical subdivisions within each topic.

Descriptive Word Index. The Descriptive Word Index offered a good starting point to locate likely key numbers leading to cases pertinent to the study. An index, containing thousands of words and factual terms, accompanies each West digest. The index provides a means to look up specific terms referenced to key numbers. The key numbers then lead to headnotes and citations. Descriptive words and phrases can be used alone or in combination with other words and phrases. The researcher entered the following words and phrases individually and in various combinations into the index: teachers, school administrators, public school employees, public school employers, public sector, private sector, adverse employment action, personnel decisions, off-duty conduct, non-job related, employment law, privacy, association, due process, just cause, discipline, suspension, termination, firing, immorality, immoral behavior, misconduct in office, role model, nexus, criminal activity, alcohol, drugs, substance abuse, marital relations, divorce, and association.

\section{Shepard's Citations}

Published case law includes many judicial decisions long since overruled. Therefore, the ability to verify the current status of any case remains critical to legal research prior to assuming its value as legal precedent. Shepard's Citations allowed the researcher to 
verify the current status of each case included in the study. Shepard's is an updating process and this process is referred to as Shepardizing. ${ }^{16}$

When analyzing the current status of a case, the researcher assessed whether the case was still good law, or overruled, limited or otherwise diminished. Along with providing the current status of a case, Shepard's supplies two additional functions of significance for legal researchers. Shepard's traces the judicial history of a case by giving references to all other proceedings in the same case. A third function of Shepard's involves listing every subsequent case citing the case being Shepardized. This function provided leads to later cases. The researcher reviewed the later cases for potential on-point value as related to the study. Furthermore, Shepardizing afforded cites to a variety of secondary sources relevant to the research question.

\section{Utilizing Secondary Sources}

The researcher accessed a variety of secondary sources during the course of the study. "Secondary sources are writings about the law rather than the law itself."17 Secondary sources are never authoritative, even though they include discussion and analysis of legal doctrine. ${ }^{18}$ Secondary sources provide valuable information to a legal research agenda. These sources provide background information related to a topic, as well as assistance in interpreting the rules of law. "Secondary sources are particularly valuable... since an informative article can present an overview of a topic and open the door to the discovery of the appropriate primary sources." ${ }^{19}$ Secondary sources consist of two major categories: scholarly writings that offer critiques of the law, and materials that

\footnotetext{
${ }^{16}$ Id. at 70 .

${ }^{17}$ Russo, supra note 1 , at 41 .

${ }^{18}$ COHEN \& OLSON, supra note 2 , at 6.

${ }^{19}$ Russo, supra note 1 , at 41 .
} 
summarize the law. The following paragraphs describe the secondary sources utilized by the researcher to assist with interpretations of the law and accessing on-point cases.

\section{Periodicals and Books}

A wide array of periodicals led the researcher to relevant cases, gaining perspective on case law, and clarifying legal doctrines. The different types of periodicals accessed included law reviews, education journals, and business journals. Searching specific descriptive words in LegalTrac, a legal periodical index, assisted the researcher in finding law reviews, generally written by lawyers, law professors and students. Shepard's also provided help leading to valuable periodical sources related to the research question. In addition to law reviews, West's Education Law Reporter provided pertinent secondary materials.

The researcher secured a wealth of information pertaining to the topic from education and business journals. A comprehensive search of ERIC assisted the researcher in locating periodic materials from the educational sector. Several electronic resource lists, including ABI-Inform, Business and Industry, and Business and Management Practices led the researcher to relevant business journals.

The researcher used various books and texts to gain a further understanding of the topic. The researcher accessed books and texts related to law, education, and business, as all three disciplines provided relevant information to the topic. Black's Law Dictionary was the first source for providing definitions for the various legal concepts encountered during the course of the research. 


\section{Encyclopedias}

Encyclopedias assisted the researcher by providing insights into particular topical subjects. Legal encyclopedias contain summaries of legal rulings emerging from both federal and state judicial proceedings. One encyclopedia accessed for the study was Corpus Juris Secundum (C.J.S.) published by the West Publishing Company. C.J.S. supplied two important resources for the researcher. The C.J.S. includes footnotes citing any federal or state cases related to specific points of law. The researcher searched these citations to locate on-point cases. C.J.S. also incorporates the West key number system providing an additional opportunity for the researcher to locate relevant cases. Of the several encyclopedias used for the study, included was West's Encyclopedia of American Law.

\section{Reading The Law}

Once the researcher collected and identified the on-point cases, the researcher analyzed elements of the law for relevance to the research question: When is it legal for P-12 public school employees to discipline employers for off-duty conduct? The following paragraphs describe the standardized approach the researcher applied to reading each case and gathering the data.

\section{Briefing The Cases}

The researcher created a uniform case analysis form as a means to gather the same information from each on-point case. The standardized approach to reading case law created a consistent and comprehensive review of the relevant data as a means to answer the research question. 


\section{Key Elements from the Case Analysis Form}

The following list identifies the precise information gathered from the reading of "on point" cases:

a. Type of off-duty conduct: arrest, affiliation, alcohol, drugs, fraudulent behavior, homosexuality, inappropriate relationship with adult(s), inappropriate relationship with minor(s), marital misbehavior, pregnancy out of wedlock, sexual exhibitionism, decadence, or public display, and theft.

b. Focus of employer arguments: nexus, role model, no privacy right, no association right, no speech right, no religion right, no reputation right, due process provided, no due process was due employee, no substantive due process right, and no equal protection right.

c. Focus of employee arguments: right to privacy, right to association, right to speech, right to religion, reputation, right to procedural due process, right to substantive due process, right to equal protection of the law, no nexus, and no role model.

d. State.

e. Year of decision.

f. Court level: administrative agency hearing, state (trial, intermediate, highest), or federal (district, circuit, or Supreme).

g. Employee classification: teacher, administrator, guidance counselor, coach, athletic director, staff member, or other; tenured or non-tenured; gender. 
h. Employee loss: termination, non-renewal, revocation of license, involuntary transfer, demotion with loss of pay, demotion without loss of pay, suspended with pay, suspended without pay, negative file, or other.

i. Employer. ${ }^{20}$

j. Prevailing party at each court level plus court's reasoning.

k. Remedy received by employee: attorney fees, damages, due process, reinstatement, not stated, or nothing.

1. Did the court opinion include "role model" or "nexus" language?

m. Was there a "mixed motive" influencing the adverse employment decision?

\section{$\underline{\text { Summary }}$}

After identifying all relevant case law, the researcher read each case using the standardized analysis form. An Access database provided the means to sort the sizeable amount of data gathered and the information captured on each analysis form. The comprehensive gathering of the primary case law allowed the researcher to garner a response to the research question: When is it legal for P-12 public school employers to discipline employees for off-duty conduct?

\footnotetext{
${ }^{20}$ For the purposes of this study, the employer was the public entity or representative of the public entity. The various representatives sued included principals, school boards, individual members of school boards, and superintendents.
} 


\section{CHAPTER IV}

\section{RESULTS}

\section{Introduction}

The researcher identified 161 cases in the national reporter system related to the research question: When is it legal for P-12 public school employers to discipline employees for off-duty conduct? The cases spanned from 1898 to 2004 .

(see Table 1).

Table 1: Legal right given focus in court decision of all identified cases by decade.

\begin{tabular}{|c|c|c|c|c|c|c|c|c|c|c|}
\hline $\begin{array}{l}\text { Legal Right Given Focus } \\
\text { in Court Decision }\end{array}$ & $\begin{array}{l}\text { Pre- } \\
\text { 30's }\end{array}$ & 30's & 40's & 50's & 60's & 70's & 80's & 90's & $\begin{array}{l}\text { Post- } \\
90 \text { 's }\end{array}$ & Total \\
\hline Right to Privacy & & 2 & & & 3 & 4 & 5 & 2 & & 15 \\
\hline Employer & $=$ & 2 & ?.? & $t=$ & 2.: & 3 & 1 & 1 & & $=7$ \\
\hline Employee & & - & & & 2 & 1 & 4 & 1 & & 9 \\
\hline Freedom of Association & & & & 1 & 1 & 3 & & 1 & 1 & 7 \\
\hline Employer & & 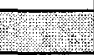 & 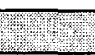 & 1 & & 1 & & 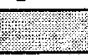 & 1 & 3 \\
\hline Employee & & & & & 1 & 2 & & 1 & & 4 \\
\hline Freedom of Speech & & & & & 1 & 4 & 4 & 4 & 1 & 14 \\
\hline Emplover & & 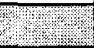 & 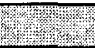 & 29 & res:enter & 3 & 2 & 2 & (2) & 8 \\
\hline $\begin{array}{r}\text { Employee } \\
\text { Em }\end{array}$ & & & & & 1 & 1 & 2 & 2 & & 6 \\
\hline Freedom of Religion & & & & & & & & & 1 & 1 \\
\hline Employer & & $\sqrt{3}$ & 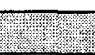 & & & 4 & 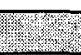 & & ?ex & 1 \\
\hline Employee & & & & & & & & & & \\
\hline Right to Reputation & & & & & & 3 & & 3 & & 6 \\
\hline Employer & 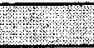 & 3 & 5 & 3 & Jis & 1 & 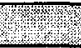 & $\sqrt{3} 3$ & 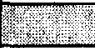 & 72. \\
\hline Employee & & & & & & 2 & & & & 2 \\
\hline Procedural Due Process & & & 1 & 5 & 6 & 21 & 8 & 12 & 3 & 56 \\
\hline Employer & 53 & $=$ & 1 & 5 & 2 & 12 & 3 & 10 & (2) 1 & 34 \\
\hline Employee & & & & & 4 & 9 & 5 & 2 & 2 & 22 \\
\hline Substantive Due Process & 1 & & & 2 & 3 & 18 & 20 & 14 & 8 & 66 \\
\hline Employer & $\sqrt{1}$ & 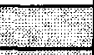 & 5 & 1 & 2 & 3.9 & 16 & 8 & 6 & $=43$ \\
\hline Whe & tive? & $\sqrt{3.1}$ & (3) & 1 & 1 & 9 & 4 & 6 & (5) & 23 \\
\hline Equal Protection & & & & & 1 & 6 & 3 & 5 & 1 & 16 \\
\hline Employer & & 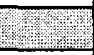 & & 4 & 1 & 3 & 2 & 2 & 1 & 9 \\
\hline Employee & & & & & & 3 & 1 & 3 & & 7 \\
\hline
\end{tabular}

*The total equals more than 161 , as courts rendered opinions on more than one legal right in several cases. 
The courts rendered decisions in these cases on the following legal rights: right to privacy, freedom of association, freedom of speech, freedom of religion, right to reputation, procedural due process, substantive due process, and equal protection under the law

A study of the cases identified thirteen types of off-duty conduct that led to P-12 public school employers disciplining employees. The following types of off-duty conduct emerged in the case law: affiliation, alcohol, drugs, fraudulent behavior, homosexuality, inappropriate relationship with adult(s), inappropriate relationship with minor(s), marital misbehavior, pregnancy out-of-wedlock, sexual exhibitionism and public display of sex, theft and robbery, other criminal behavior ${ }^{1}$, and other non-criminal behavior ${ }^{2}$ (see Table 2).

Table 2: Types of off-duty conduct identified in the case law.

\begin{tabular}{|l|c|c|}
\hline Type of Off-Duty Conduct & Number of Cases & $\%$ \\
\hline Affiliation & 13 & $8 \%$ \\
\hline Alcohol & 9 & $5 \%$ \\
\hline Drugs & 33 & $21 \%$ \\
\hline Fraudulent Behavior & 6 & $2 \%$ \\
\hline Homosexuality & 10 & $7 \%$ \\
\hline Inappropriate Relationship w/Adult & 9 & $5 \%$ \\
\hline Inappropriate Relationship w/Minor & 11 & $8 \%$ \\
\hline Marital Misbehavior & 7 & $3 \%$ \\
\hline Pregnancy Out-of-Wedlock & 9 & $5 \%$ \\
\hline Sexual Exhibitionism/Public Display & 10 & $7 \%$ \\
\hline Theft/Robbery & 11 & $8 \%$ \\
\hline Other Criminal Conduct & 24 & $16 \%$ \\
\hline Other Non-Criminal Conduct & 9 & $5 \%$ \\
\hline
\end{tabular}

\footnotetext{
' Other criminal off-duty conduct identified in the case law included: aggravated assault, bribery, criminal trafficking of counterfeit goods, extortion and perjury, federal income tax evasion, homicide, illegal gaming operations, misuse of firearms, simple assault, and nonspecified prior felonies.

${ }^{2}$ Other non-criminal off-duty conduct identified in the case law included: public advocacy against compulsory public education, bartending job, outside employment (ranging from sales jobs to cattle ranching), outside liquor business, sex change operation, and speech against employing school districts.
} 


\section{$\underline{\text { Judicial Views }}$}

\section{Right to Privacy}

The right to privacy speaks to the limited power of government and for people conducting their lives free from governmental intrusion when making choices concerning personal matters. In a basic sense, privacy means being left alone. ${ }^{3}$ In this regard, the right to privacy is germane to each case related to off-duty conduct. Employees specifically claim a right to privacy in several identified cases.

The researcher identified fifteen cases where the court determined the outcome based on the right to privacy. Of these cases, employers prevailed seven times and employees prevailed eight times. Employees suffered loss of their positions in all fifteen cases based on the six of the identified types of off-duty conduct (see Table 3).

Table 3: Types of off-duty conduct in right to privacy cases by prevailing party.

\begin{tabular}{|l|c|c|c|}
\hline Type of Off-Duty Conduct & $\begin{array}{c}\text { Number of } \\
\text { Cases }\end{array}$ & $\begin{array}{c}\text { Employer } \\
\text { Prevails }\end{array}$ & $\begin{array}{c}\text { Employee } \\
\text { Prevails }\end{array}$ \\
\hline Homosexuality & 1 & & 1 \\
\hline Marital Misbehavior & 3 & 2 & 1 \\
\hline Out-of-Wedlock Pregnancy & 4 & & 4 \\
\hline Sexual Exhibitionism/Public Display & 3 & 3 & \\
\hline Theft/Robbery & 2 & 1 & 1 \\
\hline Other Non-Criminal Conduct rotals & 2 & 1 & 1 \\
\hline \multicolumn{2}{r|}{$\quad r$} & & 7 \\
\hline
\end{tabular}

In addition to claiming a right to privacy, employees argued association, speech, reputation, and due process rights. In these cases, all the employees sought reinstatement. Employers disputed the employees' claims by making a variety of arguments but only

\footnotetext{
${ }^{3}$ See Chapter 2, p. 45 for further discussion on the right of privacy.
} 
one employer argued no deprivation of right to privacy. ${ }^{4}$ These cases, ranging from 1930 to 1992 , involved fourteen teachers, one guidance counselor, and one staff member.

\section{Employer Prevails. ${ }^{5}$}

When courts favored the employers on the issue of privacy, a consistent theme emerged. When the private conduct of an employee became public, that conduct no longer enjoyed protection under the right to privacy. Three cases involve sexual exhibitionism or a public display of sex. Of these three cases, two received judicial consideration in 1973. Courts consistently uphold disciplinary action, including termination, when employees engage in a public display of sex.

A California court found so-called "swinger's clubs" exceed what a teacher can expect to keep private. Pettit, a teacher with an exemplary teaching record, belonged to a "swingers" club with her husband. ${ }^{6}$ During an undercover police investigation, officers observed Pettit engage in sexual intercourse and oral sex with several men other than her husband. Police arrested and charged her with a misdemeanor violation. Pettit and her husband also appeared on a television talk show advocating partner swapping and other nontraditional sexual practices. Though Pettit and her husband wore disguises on the show, at least one teacher recognized Pettit. After the show aired, Pettit discussed the show with colleagues. The state board began proceedings to revoke her teaching credentials on the grounds of moral turpitude and unfitness to teach.

\footnotetext{
${ }^{4}$ Only one employer argued no deprivation of a right to privacy. See Ross $v$. Springfield Sch. Dist., 691 P.2d 509 (Or. Ct. App. 1984).

${ }^{5}$ See Baird v. Sch. Dist., 287 P. 308 (Wyo. 1930); Hainline v. Bond, 824 P.2d 959 (Kan. 1992); Horosko v. Sch. Dist., 6 A.2d 866 (Pa. 1939); Mescia v. Berry, 530 F.2d 969 (4 ${ }^{\text {th }}$ Cir. 1975); Pettit v. State Bd. of Educ., 513 P.2d 889 (Cal. 1973); Ross v. Springfield Sch. Dist., 691 P.2d 509 (Or. Ct. App. 1984); and Wishart v. McDonald, 367 F.Supp. 530 (D. Mass. 1973).

${ }^{6}$ Pettit v. State Bd. Of Educ., 513 P.2d 889 (Cal. 1973).
} 
Relying on Morrison, ${ }^{7}$ Pettit claimed her right to privacy protected her sexual activities. This court, though, distinguished Pettit's behavior from that of Morrison's. While Morrison's conduct occurred in private and between two people, Pettit's conduct not only involved multiple persons but other people observed her conduct. "Plaintiff's performance certainly reflected a total lack of concern for privacy, decorum or preservation of her dignity and reputation." ${ }^{8}$ Furthermore, her television appearance indicated to the court the very public nature of her conduct and lifestyle. ${ }^{9}$ Pettit's claim of privacy failed and the court upheld the state board's revocation decision.

In the same year as Pettit, a Massachusetts case, Wishart v. McDonald, ${ }^{10}$ also stemmed from a teacher's termination for sexual exhibitionism. On multiple occasions Wishart's neighbors observed him dressing and undressing a mannequin in his yard. At times he even caressed the mannequin. The neighbors reported Wishart's conduct to school officials and school officials investigated. After making observations of Wishart's conduct the school board terminated him with pay for the remainder of the school year, though he possessed an excellent teaching record.

Wishart claimed a personality disorder caused his conduct with the mannequin. Since he sought psychiatric treatment, he brought suit against the school board to regain his position. Wishart asserted conduct on his own property enjoyed constitutional protection. The court rejected this privacy argument, finding his so called "private" conduct often occurred in public view. "On various occasions the conduct was public in nature or at least was carried on with such reckless disregard of whether he was observed that it lost

\footnotetext{
${ }^{7}$ See 461 P.2d 375 (Cal. 1969). See Chapter 2, p. 43 for further discussion on Morrison.

${ }^{8}$ Pettit, 513 P.2d at 893.

${ }^{9} \mathrm{Id}$.

${ }^{10} 367$ F.Supp. 530 (D. Mass. 1973).
} 
whatever private character it might have had."11 No constitutional invasion of Wishart's privacy occurred when school officials observed him on his property and based the termination on those observations.

In 1984, the court considered a third case where an employee claimed a right to privacy after engaging in behavior involving a public display of sex. In Ross $v$. Springfield School District ${ }^{12}$ a tenured male teacher engaged in a homosexual act in public. Police officers observed Ross engaging in homosexual activities in an adult bookstore during the course of an undercover investigation. Though police never arrested Ross, his behavior became widely known throughout his community. Parents complained to school administrators, who ultimately dismissed him, after nineteen years of employment, for gross unfitness and immorality.

Ross brought suit claiming the Constitution afforded protection for his off-duty conduct under his right to privacy. The court disagreed, emphasizing that Ross' action violated standards of public decency.

Engaging in sexual intercourse publicly is universally condemned. In this case, appellant's engaging in sexual intercourse in a commercial establishment without a reasonable attempt to assure complete privacy is activity so reprehensible and so universally condemned that appellant was bound to know it would violate, as we conclude that it did, the standard of sexual privacy of both the people of Oregon as a whole and the school community. ${ }^{13}$

Ross chose to have sex in a public place where he knew the potential existed for others to observe him. Constitutional protection did not apply to Ross' actions and the court upheld his termination for grounds of gross unfitness and immorality.

\footnotetext{
${ }^{11} I d$. at 535 .

${ }^{12} 691$ P.2d 509 (Or. Ct. App. 1984).

${ }^{13} \mathrm{Id}$. at 511 .
} 
Although more than ten years separated Pettit, Wishart and Ross, the outcome was the same. When sexual activity occurs in a public place, especially when others see the sexual activity, that activity no longer enjoys constitutional protection under a right to privacy.

Employees argue a right to privacy when disciplined for conduct involving their marital relationships. While marital behavior remains distinctly different from the above cases involving public display of sex, a similar outcome emerges from judicial review. Courts favored the employers in the following two cases involving a claimed right to privacy by the employees.

In a 1930 case, Baird $v$. School District, ${ }^{14}$ school officials terminated a teacher after he assaulted and battered his wife. His actions led to his arrest and conviction, and a fine of five dollars. After a hearing, the school board found Baird guilty of misconduct. Baird claimed his actions involved a private matter and school officials inappropriately terminated him.

The Supreme Court of Wyoming found his conduct more than a matter of personal concern. Knowledge of Baird's conduct swept through the small community where he lived and taught. "Riverton is a small community. The arrest of the plaintiff and his confinement in jail was unusual, and the fact thereof was apt to be on the tongue of every one in the community, including the school children." 15 Conduct so widely known no longer enjoys constitutional protection.

\footnotetext{
${ }_{14}^{14} 287$ P. 308 (Wyo. 1930).

${ }^{15}$ Id. at 317 .
} 
Forty years after Baird, a court heard another case involving marital behavior. In Mescia v. Berry ${ }^{16}$ ongoing marital problems between Mescia and his wife culminated in an incident where Mrs. Mescia entered his classroom and threatened his life. Many students witnessed this incident. When school officials expressed concern over the incident, Mescia indicated he could not control the actions of his wife. District officials decided not to offer Mescia a teaching contract for the following school year.

Mescia claimed school officials based their decision to not renew his contract on his marital problems and, as such, violated his right to privacy. The court rejected his claim. While recognizing that marital issues usually warrant constitutional protection, the court stated: "Plaintiff's domestic difficulties have spilled over into the schoolhouse itself. Plaintiff's testimony indicates the school district's awareness of the death threat his wife made in his classroom in front of his students."17 The court agreed that Mescia possessed the constitutionally protected right to marry any person he chose, but that right did not afford protection for domestic disputes in the classroom of a public school.

While forty-five years separated these two cases, employers prevailed in both for a similar reason. The courts found neither teacher's behavior protected under a right to privacy, as their marital behavior received so much public attention. In regard to Mescia, school officials also became increasingly concerned about potential safety issues, since his marital behavior actually interrupted the school day on at least one occasion.

Two additional cases where employers prevailed on the issue of right to privacy involved one instance of criminal behavior and one instance of non-criminal behavior.

\footnotetext{
${ }^{16} 530$ F.2d 969 (4th Cir. 1975).

${ }^{17}$ Id. at 976.
} 
Although the facts differ in these two cases, the courts reached like conclusions based on the public nature of the behavior.

In 1992, the Kansas state board of education revoked the teaching credentials of a tenured high school teacher. ${ }^{18}$ Hainline's off-duty conduct involved robbing a furniture store. Police found Hainline hiding on the premises. Hainline's arrest and subsequent criminal charges led to an immediate suspension. Hainline entered a diversion agreement to resolve his criminal charges. The state board still proceeded with revocation proceedings against Hainline.

The court found Hainline's privacy argument unconvincing. Relying on Wishart, ${ }^{19}$ the court maintained the right to privacy “. . . may be surrendered by public display." 20 Certainly committing a robbery involves a public offense. The court afforded no right to privacy regarding Hainline's conduct.

The consistent acts of the court to uphold discipline for off-duty conduct stretches through much of the twentieth century. In 1939, fifty years prior to Hainline, another case involved a right to privacy claim. ${ }^{21}$ Horosko taught in a rural school district in Pennsylvania. Her husband owned and operated a restaurant across the street from the school that served beer, maintained slot and pinball machines, and often hosted dice games. On her off-duty time, Horosko worked as a waitress and bartender in the establishment. Horosko occasionally drank beer in front of her students and shook dice with customers. On her yearly evaluation Horosko received a less than passing score. District officials discharged Horosko on grounds of incompetency and immorality.

\footnotetext{
${ }^{18}$ Hainline v. Bond, 824 P.2d 959 (Kan. 1992).

${ }^{19} 367$ F.Supp. 530 (D. Mass. 1973).

${ }^{20}$ Hainline, 824 P.2d at 964.

${ }^{21}$ Horosko v. Sch. Dist., 6 A.2d 866 (Pa. 1939).
} 
The Supreme Court of Pennsylvania denied Horosko's claim of a privacy right. The court offered no protection to Horosko, as her conduct occurred publicly and became known throughout the community. Also, the court emphasized the public role teachers held in their communities. "One result of the choice of a teacher's vocation may be to deprive him of the same freedom of action enjoyed by persons in other vocations."22

When employers prevail on the issue of right to privacy in the cases involving offduty conduct of P-12 school employees, a consistent theme emerges from the case law. When conduct and behavior become public in nature, courts do not afford constitutional protection to that conduct and behavior. In particular, when sexual activity takes place in a location where others can view, that activity no longer retains any semblance of privacy. While sexual activity and marriage often enjoy protection under a right to privacy, the public nature of the above situations made them public. Hainline's act of robbery and Horosko's second job in a saloon also became public actions. These seven employees could not convince the judiciary that their conduct enjoyed protection under a right to privacy.

\section{Employee Prevails. ${ }^{23}$}

The researcher identified eight cases where the judiciary found that employees' offduty conduct enjoyed constitutional protection under a right to privacy. These cases range from criminal behavior to intimate activities, such as marriage and procreation. The judicial opinions afford privacy to employees regarding certain types of behavior.

\footnotetext{
${ }^{22}$ Id. at 868.

${ }^{23}$ See Cameron v. Bd. of Educ., 795 F.Supp. 228 (S.D. Ohio 1991); Drake v. Covington County Bd. of Educ., 371 F.Supp. 974 (M.D. Ala. 1974); Eckmann v. Bd. of Educ., 636 F.Supp. 1214 (N.D. Ill. 1986), Golden v. Bd. of Educ., 285 S.E.2d 665 (W. Va. 1982); Jarvella v. Willoughby-Eastlake City Sch. Dist., 233 N.E.2d 143 (Ohio Misc. 1967); Littlejohn v. Rose, 768 F.2d 765 (6th Cir. 1985); Morrison v. State Bd. of Educ., 461 P.2d 375 (Cal. 1969); and Ponton v. Newport News Sch. Bd., 632 F.Supp. 1056 (E.D. Va. 1986).
} 
No cases express the right of privacy enjoyed by public school employees more so than cases involving pregnancy out-of-wedlock. A total of nine cases involved female employees disciplined for pregnancy out-of-wedlock. ${ }^{24}$ The following three employees claimed employers violated their constitutionally protected right to privacy based on adverse employment decisions stemming from their out-of-wedlock pregnancies.

In 1991, Ohio school officials failed to renew an unmarried teacher's contract after she opted to undergo artificial insemination. ${ }^{25}$ When Cameron decided to pursue artificial insemination, she informed her principal. The principal told Cameron the decision would not affect her employment with the district. Cameron went through the artificial insemination process but later miscarried. During this pregnancy, Cameron failed to complete a required continuing education course.

She became pregnant again about a year later, assuring her principal the pregnancy would not impact her job performance. At the end of the school year, Cameron received a poor teacher evaluation, citing lack of professionalism, a high rate of absences, a number of parental complaints, and unfair treatment towards some students. The district required Cameron to work with a mentor for the next school year. When Cameron requested maternity leave in October 1988, both her mentor and her principal met with her. During the meeting they raised the issue of being a single parent and asked whether Cameron realized the difficulties involved in raising a child alone. A few days after her maternity leave began, the district superintendent informed board members of Cameron's marital

\footnotetext{
${ }^{24}$ See Andrews v. Drew Mun. Separate Sch. Dist., 371 F.Supp. 27 (N.D. Miss. 1973); Avery v. Homewood City Bd. of Educ., 674 F.2d 337 (5th Cir. 1982); Brown v. Bathke, 566 F.2d 588 (8th Cir. 1977); Cameron v. Bd. of Educ., 795 F.Supp. 228 (S.D. Ohio 1991); Drake v. Covington County Bd. of Educ., 371 F.Supp. 974 (M.D. Ala. 1974); Eckmann v. Bd. of Educ., 636 F.Supp. 1214 (N.D. Ill. 1986); N.M. State Bd. of Educ. v. Stoudt, 571 P.2d 1186 (N.M. 1977); Ponton v. Newport News Sch. Bd., 632 F.Supp. 1056 (E.D. Va. 1986); and Reinhardt v. Bd. of Educ., 311 N.E.2d 710 (Ill. App. Ct. 1974).

${ }^{25}$ Cameron, 795 F.Supp. 228 (S.D. Ohio 1991).
} 
status and her artificial insemination. The superintendent later decided not to recommend Cameron for a contract the next school year and the board followed his recommendation.

Cameron sued school officials stating the board violated her right to privacy. Citing her lack of professionalism and a host of other issues, district officials claimed they possessed legitimate reasons for not renewing Cameron's contract. They requested a summary judgment from the court, but the United States district court favored Cameron. Relying on various U.S. Supreme Court cases, ${ }^{26}$ this court stated, "A woman has a constitutional privacy right to control her reproductive functions. Consequently, a woman possesses the right to become pregnant by artificial insemination."27

A female employee also retains the right to choose her own marital status under the constitutional guarantee of privacy. Prior to Cameron, a 1986 case afforded the right to privacy to an unmarried teacher's choice to bear a child. ${ }^{28}$ At the end of the 1983 school year, Ponton, an unwed teacher who became pregnant, informed her supervisor of the situation, but did not notify the district's personnel department. During the summer Ponton received and signed a contract for the upcoming school year. At the end of summer Ponton's supervisor asked her if she got married. After Ponton responded no, her supervisor advised her to discuss the situation with the district personnel office.

The personnel department officials gave Ponton three choices: get married, take a leave of absence, or resign. Furthermore, they told her she would not teach while unmarried and pregnant, as this set a bad example for the students. Also, personnel officials said some might interpret Ponton's pregnancy and unmarried status as the

\footnotetext{
${ }^{26}$ See Griswold v. Connecticut, 381 U.S. 479 (1965); Eisenstatdt v. Baird, 405 U.S. 113 (1972); and Roe v. Wade, 410 U.S. 113 (1973).

${ }^{27}$ Cameron, 795 F.Supp. at 237.

${ }^{28}$ Ponton v. Newport News Sch. Bd., 632 F.Supp. 1056 (E.D. Va. 1986).
} 
district giving sanction or approval to out-of-wedlock pregnancy. If Ponton chose to take a parental leave of absence, the district refused to guarantee her the same position on her return to work. When a married employee took a parental leave of absence, the district allowed that employee to return to the same position. Ponton saw the parental leave as the only option. After giving birth, she waited a full year without reinstatement by the school district to any position.

For Ponton to prevail on a privacy claim required the court to find the right to bear a child protected under the right of privacy. The court first determined whether district officials forced Ponton to take leave because her out of wedlock pregnancy. Additionally, the court evaluated whether Ponton proved her interests in having a child out-of-wedlock outweighed the district's interest of Ponton performing effectively her teaching responsibilities. The court found that the school district's actions violated Ponton's constitutionally protected right to privacy. Citing several U.S. Supreme Court rulings ${ }^{29}$ this court affirmed that the right of an unmarried woman to bear a child enjoys constitutional protection. "It is undisputed that plaintiff's exercise of this right was the reason she was forced to take leave of absence, for if she had been either married and pregnant or single and non-pregnant, she would not have been forced to take the leave."30

Furthermore, the court declared the school's interest in protecting school children from exposure to an unmarried and pregnant teacher yielded no legitimate interest. Relying on Pickering, ${ }^{31}$ this court indicated that employees do not forfeit all of their constitutional rights when they accept employment. The court also depended on the U.S.

\footnotetext{
${ }^{29}$ See Griswold, 381 U.S. 479 (1965); and Eisenstadt, 405 U.S. 438 (1972).

${ }^{30}$ Ponton, 632 F.Supp. at 1062.

${ }^{31}$ See 391 U.S. 563 (1968). See chapter 2, p. 41 for further discussion on Pickering.
} 
Supreme Court's ruling in Connick v. Myers ${ }^{32}$ to employ a balancing test between an employee's constitutional rights and the legitimate interests of the employer. In balancing the school's interest against the interests of Ponton, no proof existed that Ponton's exercise of her constitutionally protected right would harm the work of the school district or that she became an advocate for out-of-wedlock pregnancy. ${ }^{33}$ She chose to have a baby on her own and made a very personal decision, which enjoyed constitutional protection under the right to privacy.

Courts previously examined the issue of right to privacy for employers who became pregnant out-of-wedlock. Prior to Ponton, a similar judicial outcome in 1974 recognized that an employee possesses a constitutional right to privacy in regards to pregnancy outof-wedlock. ${ }^{34}$ Drake held a tenured teaching position and became pregnant during the 1973 school year. The board notified Drake by letter of the nonrenewal of her contract, citing immoral behavior. The letter stated Drake became pregnant while unmarried. Drake requested and received a hearing with the board. During the hearing, Drake admitted to having sex with her fiancé. The board superintendent also requested Drake's doctor appear at the hearing. Drake's doctor testified and submitted her positive pregnancy tests to the board. Drake's gave no consent to the release of her medical records. Board officials failed to renew Drake's teaching contract.

Drake brought suit against the school board alleging violation of her right to privacy. The district court referenced the right of personal privacy guaranteeing certain "zones of privacy," ${ }^{, 35}$ including procreation and other aspects relating to raising a family. While

\footnotetext{
${ }^{32}$ See 461 U.S. 138 (1983).

${ }^{33}$ Ponton, 632 F.Supp. at 1062.

${ }^{34}$ Drake v. Covington County Bd. of Educ, 371 F.Supp. 974 (M.D. Ala. 1974).

${ }^{35}$ See Griswold, 381 U.S. 479 (1965).
} 
Drake possessed a constitutionally protected right to choose to have a baby out-ofwedlock, the school board possessed no compelling interest to keep her out of the classroom. The school board made no finding that Drake's claimed immorality affected her competency or fitness as a teacher." ${ }^{, 36}$ Absent a compelling reason, the court found the school board deprived Drake of her constitutionally protected right to privacy.

In Cameron, Ponton, and Drake, the judiciary recognized that employees possess constitutional protection related to matters of procreation, regardless of marital status. The decision to bear a child is a private decision and enjoys protection under a right to privacy. Furthermore, the courts did not distinguish between different types of impregnation, such as natural or artificial.

While courts afford privacy protection to issues of procreation, a right to privacy, may also protect marital matters. The court identified a right to privacy for a Kentucky school teacher in $1985 .{ }^{37}$ Littlejohn taught elementary school in Kentucky for two years. Under Kentucky law, at this time, nontenured teachers automatically received renewal contracts unless they received notice to the contrary. By the statutorily established date, the district began making hiring decisions and Littlejohn's principal highly recommended her for a new contract. Littlejohn and her husband of nine years separated and divorced during the summer. She received no contract extension.

Littlejohn believed the district based the nonrenewal on her divorce proceedings and brought suit in United States district court. Several school board members testified they considered Littlejohn's divorce proceedings during the decision making process, but the

\footnotetext{
${ }^{36}$ Drake, 371 F.Supp. at 978.

${ }^{37}$ Littlejohn v. Rose, 768 F.2d 765 (6th Cir. 1985).
} 
court ruled for the district because Littlejohn possessed no expectation of employment as a nontenured teacher.

The Sixth Circuit Court of Appeals agreed that Littlejohn possessed no expectation of employment due to her nontenured status, but this court found the lower court overlooked a valid constitutional issue. The fundamental issue involved Littlejohn's right to privacy and not a property right of continued employment. "By focusing on whether Littlejohn had any right to employment, the district court missed the key inquiry: Whether the school board or Superintendent Rose could, without sufficient justification, deny public employment because of involvement in a constitutionally protected activity.,38

The United States Supreme Court established that the right to privacy includes matters relating to marriage and procreation. "Allowing the board to refuse to renew a teaching contract because a teacher is undergoing divorce could possibly subject untenured teachers to painful consequences due to their marriage decisions. ${ }^{39}$ Littlejohn prevailed on appeal and the court reversed the lower court decision.

In addition to employers prevailing on issues of pregnancy out-of-wedlock and marriage relations, the courts afforded privacy rights to two employees involved in homosexual conduct and theft conduct respectively. In Morrison v. State Board of Education, ${ }^{40}$ a teacher of exceptional children who possessed an excellent teaching record engaged in an adult male relationship that led to one incident of homosexual activity. Morrison resigned his teaching position and the state board revoked his teaching credentials. Board officials based the revocation on immoral and unprofessional conduct.

\footnotetext{
${ }^{38} I d$. at 769.

${ }^{39} \mathrm{Id}$.

${ }^{40} 461$ P.2d 375 (Cal. 1969). See Chapter 2, p. 43 for further discussion on Morrison.
} 
Morrison, appealing the state's decision to the California Supreme Court, contended his actions enjoyed protection under his right to privacy. In order to determine the legality of the state action, the Court considered the following factors:

1. The likelihood that conduct may have adversely affected students or fellow teachers;

2. The degree of such adversity anticipated;

3. The proximity or remoteness in time of the conduct;

4. The type of teaching certificate held by the party involved;

5. The extenuating or aggravating circumstances, if any, surrounding the conduct;

6. The praiseworthiness or blameworthiness of the motives resulting in the conduct;

7. The likelihood of the recurrence of the questioned conduct; and

8. The extent to which disciplinary action may inflict an adverse impact or chilling effect upon the constitutional rights of the teacher involved or other teachers. ${ }^{41}$

On the basis of these factors, the Court found that state officials failed to establish any relationship, or nexus, between Morrison's off-duty conduct and his teaching position. Finding the revocation decision unwarranted, the Court asserted that private acts remain private when no harm occurs to professional achievement or the school community. Furthermore, employers cannot terminate or otherwise discipline an employee solely on the basis of conduct that opposes conventional community morality. ${ }^{42}$ The West Virginia Supreme Court, in Golden v. Board, ${ }^{43}$ presented a similar outcome. School officials terminated Golden's position as a guidance counselor, after she pled nolo contendere ${ }^{44}$ to a misdemeanor for shoplifting. A local newspaper published articles related to Golden's shoplifting incident and subsequent criminal proceedings. The board sent her a letter of dismissal indicating that shoplifting involved a serious act of immorality. At her hearing, Golden argued the shoplifting occurred because of her

\footnotetext{
${ }^{41}$ Id., at 386 .

${ }^{42}$ Id. at 382 .

${ }^{43} 285$ S.E.2d 665 (W. Va. 1982).

${ }^{44}$ BLACK'S LAW DICTIONARY 856-857 (7th ed. 2000). Latin for "no contest." While not admitting guilt, the person does not contest the charge(s). Many defendants prefer nolo contendere, because a guilty plea becomes admissible in a later civil lawsuit.
} 
distraught state of mind. She claimed she held several items in her hand as she walked about fifty feet outside of the store before realizing she had not paid for the items. She further claimed to be returning to the store to pay for the items when a store detective approached her. Golden provided several witnesses at the trial to attest to her professional competence. After the hearing, board members terminated Golden.

Golden argued in state court that a misdemeanor did not constitute immorality. The state court supported the school board and Golden appealed. The West Virginia Supreme Court determined that the school board wrongly applied an "abstract characterization" of immorality when examining Golden's conduct. "The board apparently adopted the view that conviction of the misdemeanor charge was per se immoral conduct ... or that it could dismiss Mrs. Golden if the Board members believed that her act was inconsistent with good order and improper personal conduct." 45

While some reasons exist for schools to scrutinize a teacher's off-duty conduct outside of the classroom, the conduct must relate to the teacher's ability to perform on the job. Otherwise, the conduct of the teacher is private conduct and the school possesses no legitimate reason to consider the conduct just because school officials believe the conduct constitutes immorality. "The right of privacy, while not absolute, must be balanced against the legitimate interest of the school board. ${ }^{, 46}$ This court found Golden's conduct enjoyed protection under a right to privacy and that the conduct did not impact her ability to perform her professional responsibilities.

\footnotetext{
${ }^{45}$ Golden, 285 S.E.2d at 669.
}

${ }^{46} \mathrm{Id}$. 
The decision in Golden differs from the decision in Hainline, ${ }^{47}$ although the facts depict a similar situation in both cases. Both employees engaged in a theft that led to criminal prosecution. In 1982, the court in Golden found the conduct private, whereas ten years later a court refused to concur that theft enjoyed any aspect of privacy. State supreme courts rendered both these decisions and came to opposite conclusions.

In regard to marital matters, marital behavior enjoys protection under a right to privacy when the behavior remains private. In Littlejohn, the divorce proceedings of a school teacher were private and deserved constitutional protection. On the other hand, courts provide no protection to marital behavior that becomes public, such as in Mescia and Baird. Courts also afford protection to matters related to procreation and refuse to allow employers to use a woman's pregnancy and married status as grounds for an adverse employment decision. Where an employee's conduct has become public, such as a public display of sex, employees fail on a claim to privacy. But where a teacher engages in a private, adult relationship that does not achieve public attention, that employee's conduct deserves constitutional protection under the right to privacy.

\section{Freedom of Association}

Freedom of association guarantees persons the right to gather and associate with anyone they choose. Although no mention of freedom of association appears in the U.S. Constitution, courts often afford constitutional protection to persons for intimate association and expressive association. ${ }^{48}$

Teachers comprised the employees in six of the freedom of association cases with a gender split of three males and three female. A seventh case involved a group of

\footnotetext{
47824 P.2d 959 (Kan. 1992).

${ }^{48}$ See Chapter 2, p. 46 for further discussion on the right to freedom of association.
} 
employees bringing suit against the state. Three employers prevailed and four employees prevailed in these cases (see Table 4).

Table 4: Types of off-duty conduct in freedom of association cases by prevailing party.

\begin{tabular}{|c|c|c|c|}
\hline Type of Off-Duty Conduct & $\begin{array}{c}\text { Number of } \\
\text { Cases }\end{array}$ & $\begin{array}{l}\text { Employer } \\
\text { Prevails }\end{array}$ & $\begin{array}{c}\text { Employee } \\
\text { Prevails }\end{array}$ \\
\hline Affiliation & 4 & 1 & 3 \\
\hline Homosexuality* & 2 & 2 & \\
\hline Inappropriate Relationship w/Adult & 1 & & 1 \\
\hline Totals & 7 & 3 & 4 \\
\hline
\end{tabular}

* These cases involved affiliation conduct, in addition to homosexual conduct.

Employees argued speech and due process rights, in addition to the right of freedom of association, in their attempts to gain reinstatement and back pay. Employers based their claims on no deprivation of freedom of association and no deprivation of the right to due process. The freedom of association cases ranged from 1954-2003.

\section{Employer Prevails. ${ }^{49}$}

Two cases presented judicial outcomes for employers based on freedom of association. The courts conclude that while employees possess the right to freedom of association, that right fails to be persuasive in some instances of adverse employment decisions. When associational activities directly affect the employer's legitimate interests, employees' arguments for the right to freedom of association do not prevail.

While sexual orientation alone is clearly not grounds for adverse employment decisions, high profile advocacy of a sexual cause or lifestyle can be grounds. Gish v. Board of Education ${ }^{50}$ involved a tenured male high school teacher who led a homosexual lifestyle. In 1972, Gish assumed the presidency of the New Jersey Gay Activists Alliance. His position afforded him multiple opportunities to represent and promote the

\footnotetext{
${ }^{49}$ See Faxon v. Sch. Comm., 120 N.E.2d 772 (Mass. 1954); Gish v. Bd. of Educ., 366 A.2d 1337 (N.J. 1976); and Melzer v. Bd. of Educ., 336 F.3d 185 (2nd Cir. 2003).

50366 A.2d 1337 (N.J. 1976).
} 
organization in the media. Shortly after he assumed his leadership role with the organization, the school board required Gish to undergo a psychiatric evaluation. The school's psychiatrist claimed that Gish's overt and public behavior demonstrated the likelihood of psychological harm to students. The overt and public nature of Gish's behavior served as the basis of the school board's request. Furthermore, the board relied on state law that afforded school officials the ability to require psychiatric evaluations when an employee's behavior departed from normal physical and mental health. ${ }^{51}$

Gish and his attorneys claimed a forced psychiatric evaluation owing to Gish's advocacy of the homosexual lifestyle and his involvement with the Gay Activists Alliance infringed his right to freedom of expressive association. The court acknowledged the school board relied solely on Gish's outside involvement in the organization and not on any instance of classroom or work misconduct. The court further acknowledged Gish possessed the right to associate freely with the organization.

The court, though, found the school board's position persuasive. The board received competent information from a psychiatrist indicating Gish's behavior deviated from normal mental health. Pointing out that school officials must possess the ability to determine the fitness of teachers, the court stated: “A teacher's fitness may not be measured solely by his ability to perform the teaching function and ignore the fact that the teacher's presence in the classroom might, nevertheless, pose a danger of harm to the students for a reason not related to academic proficiency." ${ }^{, 52}$ Gish's overt and public behavior related to his association with the Gay Activists Alliance was enough evidence for the board to require the psychiatric examination. The court further indicated that

\footnotetext{
${ }^{51}$ Id. at 1339 .

${ }^{52}$ Id. at 1340.
} 
school officials do not need to wait for harm to occur before acting: "A reasonable possibility of its occurrence warrants such action." 53

The court found that the school board never questioned Gish's right to associate with the organization but argued his actions indicated possible mental health issues that potentially affected his ability to teach. While Gish retained his freedom to associate with the organization, the court agreed that his association warranted the school board's concern.

Courts remain consistently in favor of employers using associational activities to bolster a concern regarding an employee's fitness to teach. Thirty years after Gish, the Second Circuit Court of Appeals heard a case involving a male teacher's affiliation with a gay right's activist group in $2003 .{ }^{54}$ Melzer's involvement in the North American Man/Boy Love Association (NAMBLA) included serving as editor of a newsletter and various other publications. Melzer, a self-described pedophile, admitted his sexual attraction to young males. No evidence existed that he ever acted on his attractions. Melzer's NAMBLA affiliation came to the attention of the school board, when a local television station produced a story related to NAMBLA featuring Melzer's involvement with the organization. The school board determined that Melzer's retention would cause serious harm and disruption to the school community. Many school officials and parents expressed concerns that Melzer's activities and leanings could lead to the sexual abuse of a student or students.

While Melzer maintained his association with NAMBLA deserved protection under his right to free association, the school board successfully conveyed to the court that

\footnotetext{
${ }^{53} \mathrm{Id}$.

${ }^{54}$ Melzer v. Bd. of Educ., 336 F.3d 185 (2nd Cir. 2003).
} 
Melzer's associational activities directly impacted his position. The court stated, "In the context of teaching schoolchildren Melzer's activities strike such a sensitive chord that, despite the protection afforded his activities, the disruption they cause is great enough to warrant the school's action against him." 55 The court found that the school board never denied Melzer's right to freely associate with NAMBLA. The school board's concern revolved around a contention that involvement with NAMBLA caused a direct harm and disruption to the operation of the school.

In Gish and Melzer, neither court denied the employees the right to freely associate with their respective organizations. But both courts found the employer concerns persuasive, in that allowing the employee to continue teaching could potentially disrupt the life of the school. The public nature of Gish's and Melzer's associational activities lent credence to the potential for disruption that their continued employment might create.

\section{Employee Prevails. ${ }^{56}$}

Four cases involved employees prevailing on a claim of freedom of association. Two of the cases involved intimate association, while the other two dealt with expressive association. In regard to the right to intimate association, the courts protect the freedom for employees to enter into intimate relationships without a threat that those relationships would negatively impact an employee's job. The researcher identified two such cases where employees prevailed on the right to freedom of intimate association.

\footnotetext{
${ }^{55}$ Id. at 198.

${ }^{56}$ See Alabama Educ. Ass'n v. Wallace, 362 F.Supp. 682 (M.D. Ala. 1973); LaSota v. Town of Topsfield, 979 F.Supp. 45 (D. Mass. 1997); Rackley v. Sch. Dist., 258 F.Supp. 676 (D.S.C. 1966); and Randle v. Indianola Municipal Separate Sch. Dist., 373 F.Supp. 766 (N.D. Miss. 1974).
} 
The first case, Randle v. Indianola Municipal Separate School District, ${ }^{57}$ involved an African American teacher denied employment based on the associational activities of her husband. Randle and her husband previously held jobs with the Indianola school district during which time Mr. Randle participated with other teachers in a protest against school administration. Additionally, both Randle and her husband actively participated in the Indianola Development Association, a predominantly African American organization dedicated to addressing civil rights issues.

Randle and her husband spent several years teaching in other Mississippi school districts and then Randle took several years away from teaching. When she reapplied in 1971 for an open position with the Indianola district, her former principal recommended her to the board as the most qualified applicant. The district superintendent refused to consider Mrs. Randle's application or to submit her application to the district board for approval. The superintendent indicated to several school administrators that Randle's husband was one of Indianola's most controversial persons. Furthermore, he indicated Randle was an incompetent teacher. The board denied Randle's request for a hearing, because Randle had not received endorsement by the superintendent. The board believed it owed Mrs. Randle no hearing on the matter.

The United States district court found that the denial of employment for Randle violated a constitutionally protected right of association. "Mrs. Randle cannot be punished by the School District or suffer at its hands because she elected to become the wife of Carver Randle." 58 The court found Randle entitled to employment with the Indianola school district.

\footnotetext{
${ }^{57} 373$ F.Supp. 766 (N.D. Miss. 1974).

${ }^{58}$ Id. at 770 .
} 
Over twenty years later, another teacher's intimate associational activities led to an adverse employment decision. In LaSota v. Town of Topsfield $d^{59}$ the school district denied a renewal contract to a nontenured school teacher who possessed an excellent teaching record. Beginning in 1987, Mrs. LaSota began an association with a man and lived with him out-of-wedlock until 1994, when they married. Mr. LaSota faced indictments for five counts of rape and abuse of his daughter in 1987. An appeal verdict overturned some of the indictments. Eventually, there was a dismissal of all charges, after a 1993 retrial of Mr. LaSota on the remaining counts. In the midst of the retrial, Mrs. LaSota received a subpoena at work commanding her appearance in court to testify in the action against Mr. LaSota. The superintendent expressed concern regarding Mrs. LaSota's relationship with Mr. LaSota and her principal advised her not to have Mr. LaSota continue to pick her up at school. Shortly thereafter, Mrs. LaSota received her first negative evaluation from her principal. She then received a letter of nonrenewal of her contract for the following year.

Mrs. LaSota brought suit against the town of Topsfield claiming the officials violated her constitutional right to freedom of association. The United States district court agreed with her. Relying on Roberts v. United States Jaycees ${ }^{60}$ the court asserted that freedom of association fundamentally is a part of personal liberty and therefore enjoys constitutional protection. Furthermore, the court indicated that her choices in regards to Mr. LaSota were choices related to marriage. ${ }^{61}$ She chose to cohabitate with Mr. LaSota, testify on his behalf, raise a family with him, and later marry him. These are choices that enjoyed constitutional protection under the freedom of intimate association. "LaSota has a constitutional right to associate intimately without fear that the government will use her

\footnotetext{
${ }^{59} 979$ F.Supp. 45 (D. Mass. 1997).

${ }^{60} 468$ U.S. 609 (1984).

${ }^{61}$ LaSota, 979 F.Supp. at 50.
} 
associations when making decisions concerning her employment."62 The court denied summary judgment to the town of Topsfield and ordered a hearing.

While courts afford protection for intimate relationships under the right to freedom of association, courts also extend protection for expressive association. Expressive association provides employees the right to associate with organizations promoting particular political and social viewpoints. Even when associational activities entail outspoken public action, courts grant employees free use of their right to associate. The researcher identified two cases involving an employee's successful claim to a right to association.

In Rackley v. School District ${ }^{63}$ school officials fired a tenured African American teacher during the school year. Rackley participated in the National Association for the Advancement of Colored People involving herself in numerous demonstrations, picketing, and other related activities to end segregation. As a result of her active involvement, police arrested Rackley on several occasions for breach of peace and trespassing. Though Rackley possessed an excellent teaching record, district officials terminated her contract stating neglect of duties. The superintendent cited an instance where Rackley left an extracurricular teacher's workshop to attend a civil rights protest. The superintendent previously counseled Rackley that her activities with the NAACP embarrassed the school district and the teaching profession in general.

When Rackley brought suit in United States district court, she argued the officials based her termination on her protected right of freedom of association. The court agreed with her claim. The court found that school districts possessed the responsibility to

\footnotetext{
${ }^{62} \mathrm{Id}$.

${ }^{63} 258$ F.Supp. 676 (D.S.C. 1966.)
} 
operate the school systems and, when choosing and maintaining staff, “. . school administrators must look at the whole person, both in and out of the classroom." ${ }^{64}$ The court added, though, the exercise of this responsibility was not to be exercised in an arbitrary or capricious manner. "Plaintiff was discharged by the defendant board without good and sufficient reasons for so doing." ${ }^{, 65}$ The court found that district officials based Rackley's termination on an aversion to her civil rights activities. The court determined Rackley's dismissal resulted from activities that enjoyed constitutional protection under her right to freedom of association.

While Rackley's associational activities stemmed from a specific membership in the NAACP, the next case, Alabama Education Ass'n $v$. Wallace, ${ }^{66}$ involved a restriction on non-specified associational activities. The state passed a law prohibiting pay raises for any teacher who encouraged or supported mass truancy, even for a day, or any extracurricular activity or demonstration not approved by the city, county, or state board of education. The Thomasville City Board of Education required that teachers sign a memorandum stating they had not participated in the proscribed activity. When several teachers refused to sign, the board denied them pay raises according to the state law mandate.

The Alabama Education Association brought suit on behalf of the teachers, arguing the unconstitutionality of the forfeiture provision. While the court found that the state of Alabama might possess a legitimate interest in the associational activities of its teachers, “... there is no justification for restricting the right of a teacher to engage in nonpartisan advocacy of social or political form, absent a showing that such activities reflects

\footnotetext{
${ }^{64} I d$. at 683 .

${ }^{65} \mathrm{Id}$. at 685 .

${ }^{66} 362$ F.Supp. 682 (M.D. Ala. 1973).
} 
substantially on his or her performance in the class or interferes with the regular operation of the school." ${ }^{67}$ Alabama officials defended the law by declaring it allowed schools to deal with truancy by disciplining school employees who encouraged truancy. The court, though, found the law overbroad, stating: "[The law] constitutes a comprehensive interference with associational freedom which goes far beyond what might be justified in the protection of the state's legitimate interest."

Similar in outcome to Rackley, this case affirmed that an employee's associational activities cannot become the basis for an adverse employment decision unless the employer successfully provides a legitimate reason to possess concern over those activities. For instance, the courts found the employers' interest valid in both Gish and Melzer, because the associational activities of both teachers encompassed the potential for disruption and imminent harm to occur as a result of retaining the employee.

\section{Freedom of Speech}

Freedom of speech affords "the right to express one's thought and opinions without governmental restriction, as guaranteed by the First Amendment. ${ }^{, 69}$ Using the definition above, the right to free speech protects far more than spoken and written words. Types of speech include: pure speech, symbolic speech, pornography, and commercial speech.

Courts, most notably the United State Supreme Court, consistently assert that a continuum of speech exists based on the level of constitutional protection afforded different types of speech, with pure speech enjoying the greatest protection. ${ }^{70}$

\footnotetext{
${ }^{67}$ Id. at $685-686$.

${ }^{68} \mathrm{Id}$. at 686.

${ }^{69}$ BLACK's LAW DICTIONARY, supra note 44 , at 533.

${ }^{70}$ See Chapter 2, p.48 for further discussion on the right to freedom of speech.
} 
The judiciary resolved fourteen cases on the issue of free speech. In eight of these cases, constituting a slight majority, employers prevailed, while employees prevailed in the remaining six cases. Employee losses included all the types of losses the researcher captured in the study, with the exception of demotion. These cases involved seven of the types of off-duty conduct identified in the research (see Table 5).

Table 5: Types of off-duty conduct in freedom of speech cases by prevailing party.

\begin{tabular}{|c|c|c|c|}
\hline Type of Off-Duty Conduct & $\begin{array}{c}\text { Number of } \\
\text { Cases }\end{array}$ & $\begin{array}{l}\text { Employer } \\
\text { Prevails }\end{array}$ & $\begin{array}{c}\text { Employee } \\
\text { Prevails }\end{array}$ \\
\hline Affiliation & 4 & 2 & 2 \\
\hline Alcohol & 1 & 1 & \\
\hline Fraudulent Behavior & 1 & 1 & \\
\hline Homosexuality & 3 & 1 & 2 \\
\hline Inappropriate Relationship w/Minor & 1 & 1 & \\
\hline Other Criminal Conduct & 1 & 1 & \\
\hline Other Non-Criminal Conduct & 3 & 1 & 2 \\
\hline 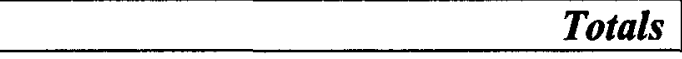 & 14 & 8 & 6 \\
\hline
\end{tabular}

Employees argued a variety of constitutional rights when they sought reinstatement. Employers defended their actions by arguing no deprivation of the following rights: speech, reputation, due process, and equal protection. These cases, ranging from 1966 2003, involved seven teachers, three teachers who also held coaching positions, one administrator, one guidance counselor, one staff member, and one mixed group of employees.

\section{Employer Prevails. ${ }^{71}$}

When an employer's action does not restrict an employee's right to free speech, a claim of infringement of right to free speech fails. In Montefusco v. Nassau County, ${ }^{72}$ a

\footnotetext{
${ }^{11}$ See Gish v. Bd. of Educ., 366 A.2d 1337 (N.J. 1976); Logan v. Warren County Bd. of Educ., 549 F.Supp. 145 (S.D. Ga. 1982); Meinhold v. Clark County Sch. Dist., 506 P.2d 420 (Nev. 1973); Melzer v. Bd. of Educ., 336 F.3d 185 (2nd Cir. 2003); Montefusco v. Nassau County, 39 F.Supp.2d 231 (E.D.N.Y. 1999); Pordum v. Bd. of Regents, 357 F.Supp. 222 (N.D.N.Y. 1973); Rowland v. Mad River Local Sch. Dist., 730 F.2d 444 (6th Cir. 1984); and Vukadinovich v. Bd. of Sch. Tr., 978 F.2d 403 (7th Cir. 1992).
} 
tenured high school teacher used a false name when he developed some seedy pictures of teenage minors. The photo lab contacted state police. Montefusco admitted he possessed voyeur tendencies and liked to use the pictures for sexual gratification. The police reported the incident to the state board of education, even though no criminal charges resulted from the police investigation. The state board contacted Montefusco's local school officials who suspended him with pay while investigating the issue. School officials levied a charge of conduct unbecoming a teacher against Montefusco, but a hearing panel later dismissed that charge.

Even though school officials did not pursue the charge against him, Montefusco brought suit in federal district court alleging violation of his first amendment right to free speech. The district court affirmed that speech includes more than verbal expression, but that protected speech requires a message and an audience. The court did not need to decide whether or not Montefusco's pictures involved protected speech. "There is no evidence in the record that the defendants attempted to prohibit Montefusco from taking the photos, developing the photos, selling the photos, possessing the photos, or displaying the photos. There is also no evidence to indicate that the defendants sought to stifle any message. ${ }^{, 73}$ Montefusco's claim failed, as school officials never sought to abridge his activities enjoying protection under a right to free speech.

As in Montefusco, claims relying on a denial of free speech must show a limiting of an employee's constitutionally protected right to free expression and opinion. Courts often use the Mt. Healthy ${ }^{74}$ analysis to resolve a freedom of speech claim. Mt. Healthy requires the plaintiff to show that a protected activity, such as speech, was the

\footnotetext{
7239 F.Supp.2d 231 (E.D.N.Y. 1999).

${ }^{73} \mathrm{Id}$. at 242.

${ }^{74}$ Mt. Healthy v. Doyle, 429 U.S. 274 (1977).
} 
"substantial or motivating factor" for the adverse employment decision. In 1982, a federal district court considered a right to free speech claim when school officials did not renew an employee's teaching contract after his conviction on charges of tax fraud. ${ }^{75}$ Logan claimed his nonrenewal stemmed from his running for school superintendent in Warren County. After losing the race, Logan challenged the election results in superior court to no avail.

The court used the Mt. Healthy analysis, ${ }^{76}$ becuase both parties claimed different motives for the nonrenewal. The court found school officials based their decision solely on Logan's criminal conduct. "It is abundantly clear that the decision to not renew Logan's contract would have been made regardless of his candidacy for office or his decision to file suit regarding that election" ${ }^{\text {"77 }}$ Thus, the court found no violation occurred to Logan's right to freedom of speech.

Actions by employees that possess both the expression of beliefs and action on those same beliefs can be difficult to divide. But courts clearly favor employers when the cause for discipline is attributed to an action, not just an expression of opinion.

In a Nevada Supreme Court case, Meinhold v. Clark County School District, ${ }^{78}$ a similar judicial outcome emerged, although the court turned to the Pickering ${ }^{79}$ precedent. Although employed as a public school teacher, Meinhold spoke out against compulsory education. He even encouraged his two daughters to stay out of school, and their repeated absences led to action by civil authorities. As a result of his advocacy against compulsory

\footnotetext{
${ }^{75}$ Logan v. Warren County Bd. of Educ., 549 F.Supp. 145 (S.D. Ga. 1982).

${ }^{76} 429$ U.S. 274 (1977).

${ }^{77}$ Logan, at 151 .

${ }^{78} 506$ P.2d 420 (Nev. 1973).

${ }^{79}$ Pickering v. Bd. of Educ., 391 U.S. 563 (1968). See Chapter 2, p. 41 for a further discussion on Pickering.
} 
education, school officials refused to renew his contract for the following year on grounds of unprofessional conduct and insubordination.

After failing to receive a new teaching contract, Meinhold sued the school district, claiming the nonrenewal violated his constitutionally protected right to free speech. The Nevada Supreme Court turned to Pickering ${ }^{80}$ to begin the analysis of Meinhold's claim. The court agreed that teachers do not relinquish their First Amendment rights to speak as citizens on matter of public concern. The court, though, found that that school officials did not make the adverse employment decision based on the content of Meinhold's speech. Meinhold actively had encouraged his daughters to remain out of school, which violated Nevada state law. School officials considered his unlawful conduct when making the adverse employment decision. "The appellant expressed disagreement with the laws requiring compulsory attendance at school and his carrying out of that attitude into effect was a prerogative he was entitled to indulge but with it went the price that he might not be rehired." ${ }^{, 11}$ Meinhold's freedom of speech claim failed, as the court found his criminal conduct, and not his expression, caused the nonrenewal.

Even when the cause for dismissal involves speech, courts delineate between protected and unprotected speech. In 1984, the Sixth Circuit Court of Appeals relied on the Connick ${ }^{82}$ precedent in Rowland v. Mad River Local School District. ${ }^{83}$ Rowland held an untenured vocational guidance counselor position with the district. In the course of conversation, Rowland told another employee she was bisexual and currently involved in a relationship with another woman. Rowland further told the colleague about two

\footnotetext{
${ }^{80} \mathrm{Id}$.

${ }^{81}$ Meinhold, 506 P.2d at 425.

${ }^{82}$ Connick v. Myers, 461 U.S. 138 (1983). The United States Supreme Court defined protected employee speech as speech that addresses matters of public concern.

${ }^{83} 730$ F.2d 444 (6th Cir. 1984).
} 
homosexual students she counseled. The principal, after hearing about the conversation, encouraged Rowland to resign her position. After refusing to resign, Rowland proceeded to tell other employees she was bisexual and the principal again encouraged her to resign because of her sexual preferences. School officials suspended Rowland with pay for the remainder of the contract year. After Rowland filed suit in United States district court, she received an administrative position with no student contact. The school board refused to renew her contract for the next year.

When bringing suit against the district, Rowland claimed officials violated her constitutionally protected right to free speech by basing the adverse employment decision on Rowland's comments regarding her sexual preferences. For a public employee's speech to enjoy constitutional protection, the speech must typically involve a matter of public concern. The court, relying on the Connick test, ${ }^{84}$ found that Rowland's comments related to her sexual preferences did not involve any matter of public concern. "Ms. Rowland's statements were not protected speech. It is clear she was speaking only in her personal interest. There was absolutely no evidence of any public concern in the community with the issue of bisexuality among school personnel when she began speaking to others about her own sexual preferences." speech claim unfounded and favored the school district.

When an employee's speech involves a matter of public concern, justification may still exist for an employer to quell the speech. In 2003, the Second Circuit Court of Appeals considered the case of Melzer $v$. Board of Education ${ }^{86}$ This case involved a male teacher's affiliation with a gay right's activist group, the North American Man/Boy

\footnotetext{
${ }^{84}$ See Connick, 461 U.S. 138 (1983).

${ }^{85}$ Rowland, 730 F.2d at 449.

${ }^{86} 336$ F.3d 185 (2nd Cir. 2003). See Chapter 4, p. 91 for a further discussion on Melzer.
} 
Love Association (NAMBLA). Melzer, a self-described pedophile, openly admitted his sexual attraction to young males on a number of occasions. Melzer's involvement with the association included significant advocacy for NAMBLA's goals, including changing laws and attitudes about dictating sexual relationships between men and boys.

When board members terminated Melzer's high school teaching position, he sued claiming violation of his constitutionally protected right to free speech. Relying on Pickering, ${ }^{87}$ the federal circuit court disagreed. The Pickering balancing test requires government to prove the protected speech caused or could potentially cause such a disruption to government operations to justify restriction. The board satisfied the balancing test by indicating that disruption already occurred and by predicting further disruption from Melzer's speech. The court agreed Melzer possessed a protected right to express his views, stating: "The First Amendment protects the speech and association rights of an individual like Melzer, no matter how different, unpopular, or morally repugnant society may find his activities." ${ }^{98}$ The court, though, found Melzer's speech activities disrupted the life and work of the school, and therefore, found the termination decision justified.

Public school employers may proscribe an employee's off-duty conduct, even when the employee might be exercising otherwise protected free speech. Courts, though, consistently draw a narrow line around the speech activity that employers can proscribe. The next section presents case examples of employers crossing the line.

\footnotetext{
${ }^{87}$ See Pickering v. Bd. of Educ., 391 U.S. 563 (1968). See Chapter 2, p. 41 for a further discussion on Pickering.

${ }^{88}$ Melzer, 336 F.3d at 192.
} 
Employee Prevails. ${ }^{89}$

When an employer quells pure speech, an employee may successfully argue a violation of the right to freedom of speech. While teachers do make certain sacrifices when they choose the educational profession and some courts find that includes being held to a higher moral or legal standard when considering their conduct, freedom of speech is not one of those concessions. Provided an employee's statements do not cause harm to the school environment, courts grant wide latitude for the exercise of free speech.

In 1984, the Tenth Circuit Court of Appeals considered a case involving a group of employees claiming a constitutionally protected right to speech. ${ }^{90}$ The National Gay Task Force brought a legal challenge against the school board disputing the validity of a state statute requiring dismissal or suspension of any teacher for engaging in public homosexual conduct.

Specifically, the Task Force argued the statute defined public homosexual conduct as “advocating, soliciting, imposing, encouraging, or promoting private or public homosexual activity in such a way that creates a substantial risk that such conduct will come to the attention of school children or school employees." 91 The task force contended the wording of the statute infringed pure speech. The court stated: "Such statements, which are aimed at legal and social change, are at the core of First Amendment protections. ${ }^{, 92}$ Mere advocacy or promotion of an idea does not imply incitement or the potential of disruption in the school setting. Government's ability to

\footnotetext{
${ }^{89}$ See Allen v. Bd. of Educ., 584 S.W.2d 408 (Ky. Ct. App. 1979); Hall v. Marion Sch. Dist., 31 F.3d 183 (4th Cir. 1994); Nat'l Gay Task Force v. Bd. of Educ., 729 F.2d 1270 (10th Cir. 1984); Thompson v. Bd. of Educ., 711 F.Supp. 394 (N.D. Ill 1989); Weaver v. Nebo Sch. Dist., 29 F.Supp.2d 1279 (D. Utah 1998); and Williams v. Sumter Sch. Dist., 255 F.Supp. 397 (D.S.C. 1966).

${ }^{90}$ Nat'l Gay Task Force v. Bd. of Educ., 729 F.2d 1270 (10th Cir. 1984).

${ }^{91}$ Okla.Stat. tit. $70 \S 6103.15(\mathrm{~A})(2)$.

${ }^{92}$ Nat'l Gay Task Force, 729 F.2d at 1274.
} 
restrict speech depends upon the likelihood of "material" and "substantial" disruption occurring from the speech. ${ }^{93}$ The court found the statute's suppression of pure expression overbroad and, therefore, unconstitutional. The court did not strike down the remainder of the statute.

If an employee exercises a right to free speech in regard to matters of public concern, that speech enjoys protection. Two cases where employers disciplined employees for speaking on matters of public concern demonstrate this principle. A 1989 Illinois case, Thompson v. Board of Education, ${ }^{94}$ involved a high school librarian disciplined for speech activity. A local journalist contacted Thompson and requested an interview. Thompson, along with two other employees, agreed to the interview. The journalist focused on the impending teachers' strike and the quality of the inner-city schools in Chicago. When Thompson reviewed a draft of the article, she expressed disappointment in the journalist's approach to the topics. Nevertheless, the article appeared and many school employees took offense at Thompson's comments. The school superintendent confronted Thompson, insinuating a private employer would immediately fire an employee for similar comments. He further threatened Thompson with a transfer. After the superintendent documented the incident in Thompson's file, he transferred her to another school.

Using the Pickering balancing test, ${ }^{95}$ the federal district court found Thompson's comments in the article involved matters of public concern, and therefore, enjoyed

\footnotetext{
${ }^{93}$ Tinker, 393 U.S. 503 (1969). See Chapter 2, p. 42 for further discussion on Tinker.

94711 F.Supp. 394 (N.D. Ill 1989).

${ }^{95}$ Pickering v. Bd. of Educ., 391 U.S. 563 (1968). See Chapter 2, at p. 41 for further discussion of Pickering.
} 
constitutional protection. The court stated: “The content of Thompson's remarks encompassed a wide variety of topics at the forefront of contemporary public debate."

The Pickering balancing test then required the court to assess whether Thompson's speech on matters of public concern caused any disruption to the legitimate work of the school. The court found no evidence of disruption. Thompson's statements to the reporter occurred after hours on her own private time. Even though the article upset some employees, no disruption occurred. For instance, no one, student or employee, refused to use the library where Thompson worked. "The defendants presented no testimony to lend support to their claims of nascent or potential disruption."97 School officials possessed no legally acceptable interest to quell Thompson's speech on matters of public concern. Thompson's speech enjoyed constitutional protection under the first amendment right to freedom of speech.

Talking out of school, as the cliché goes, enjoys protection by the courts, even when the talking concerns internal school activities and conditions. A 1994 case, Hall v. Marion School District, ${ }^{98}$ involved school officials disciplining a teacher for speech activities. Hall wrote a letter to the editor of a local newspaper expressing indignation over school board members spending tax payer money on a luxury vacation. Hall wrote multiple letters to the editor regarding the school board's use of public funding. School officials became upset with Hall and the superintendent issued a letter to all board members. The letter insinuated school officials were looking for a reason to get rid of Hall. Furthermore, the superintendent printed an advertisement in the paper that

\footnotetext{
${ }^{96}$ Thompson, 711 F.Supp. at 401-402.

${ }^{97} \mathrm{Id}$. at 406.

${ }^{98} 31$ F.3d 183 (4th Cir. 1994).
} 
intimidated Hall and suggested she might lose her job for her comments against the board.

After board members decided to dismiss Hall, she brought suit in federal court claiming the termination deprived her of a constitutionally protected right to free speech. Finding Hall's speech related to matters of public concern, the court asserted her speech deserved protection. The court then determined whether board members decided to fire Hall because of the protected activity. "Hall had clearly shown that her protected speech was a motivating factor in her dismissal. ${ }^{, 99}$ Furthermore, Hall's speech never caused a substantial disruption to the work of the school. Hall prevailed on her claim to a constitutionally protected right to freedom of speech under the First Amendment.

Employees enjoy protection for speech regarding personal issues, but, as indicated in the previous section, courts limit these rights. Still, when an employee's speech becomes subject to viewpoint restrictions, a deprivation of free speech occurs. The 1998 case, Weaver v. Nebo School District, ${ }^{100}$ involved the discipline of a high school teacher and women's volleyball coach. Weaver's homosexual lifestyle became known when a player on the volleyball team asked her about her lifestyle and Weaver confirmed she was gay. This player refused to continue playing on the volleyball team. Weaver's homosexual lifestyle created a stir in the school community and beyond. Ultimately, school officials restricted Weaver from discussing her sexual orientation. Officials also failed to renew Weaver's contract for the volleyball coaching position.

Weaver filed claims in federal district court maintaining the school district's action violated her constitutional right to free speech under the first amendment. In assessing her

\footnotetext{
${ }^{99}$ Id. at 193.

10029 F.Supp.2d 1279 (D. Utah 1998).
} 


\section{Employee Prevails}

The following two cases involve successful claims based on the right to reputation. In one case, the employee prevailed because the school district enhanced the stigma by making public the facts of his situation. The other employee prevailed on his reputation claim by showing the stigma arose during his termination process.

The case of Bogart v. Unified School District ${ }^{118}$ involved the termination of a tenured shop teacher. Police arrested Bogart and charged him with drug possession after finding marijuana in his home. Police earlier arrested Bogart's son for drug possession, which led to the search of Bogart's home. The school district initially suspended him, pending the outcome of the criminal proceedings but reinstated him when the prosecutor delayed the trial. When the jury returned a guilty verdict against Bogart, the board met to discuss the verdict. Bogart received no notice of this meeting. School officials terminated Bogart's position for conduct unbecoming an instructor. About two weeks later district administrators held an invitation only meeting with concerned parents and students. A discussion of Bogart's guilty verdict and the district's pursuant dismissal dominated the meeting time. Bogart received no invitation to this meeting.

An appeal of the criminal proceeding favored Bogart and overturned the guilty verdict. Bogart's attorney advised the district of his client's exoneration and demanded reinstatement to his teaching position. School officials assured Bogart a discussion of his reinstatement would occur. At the next school board meeting, board members voted on teacher contracts for the upcoming school year. After the meeting and at the request of his attorney, Bogart received a nonrenewal letter. The school district offered Bogart no

${ }^{118} 432$ F.Supp. 895 (D. Kan. 1977). 
reasons for this decision nor did a hearing take place in regard to his reinstatement or a contract for the following year.

Bogart filed suit in United States district court claiming the school district's actions violated his right to reputation. After the school district refused to reinstate him, Bogart was unable to find a teaching position despite his outstanding teaching record. He claimed the stigma attached to a mid-year termination for unbecoming conduct harmed his opportunities to secure another teaching position. The court agreed with Bogart. as he possessed, "a viable liberty interest which was impaired by defendant's actions. ... The stigma that attaches to a mid-year dismissal is sufficiently injurious as to call for a hearing." 119

Additionally, the court found that district personnel specifically enhanced the stigma imposed on Bogart by conducting a meeting where they aired Bogart's criminal charges and guilty verdict. District personnel disclosed to the parents and students in attendance that the rationale for the termination involved the criminal charges. Though Bogart never received the stated reasons for his termination, the district made the reasons public to members of the community. "Charges alleged against plaintiff were thus made publicly and, it is reasonable to find, seriously damaged his good name, standing and associations in his community." ${ }^{20}$ Bogart prevailed on his reputation claim.

General statements about an employee, without a specific finding of fact, also posed problems for employers. A year after Bogart, the Fifth Circuit Court of Appeals reached a similar outcome in Dennis v. $S \& S$ Consolidated Rural High School District. ${ }^{121}$ This case involved a principal who lost his position without receiving notice of the specific reasons.

\footnotetext{
${ }^{119}$ Id. at 903.

${ }^{120} \mathrm{Id}$.

${ }^{121} 577$ F.2d 338 (5th Cir. 1978).
} 
At the hearing, the school board stated the nonrenewal benefited in the interests of the school. Individual board members cited neglect of duty and a severe drinking problem. Dennis denied these allegations and demanded a further hearing. The second hearing did not change the outcome regarding Dennis' contract.

Dennis brought suit in United States district court, claiming a deprivation of his right of reputation without due process of law. District officials argued no injury to Dennis' reputation, as he secured employment with another school system. The district court found in favor of Dennis and the district appealed. The appeals court upheld the lower court decision on the reputation issue. Relying on Paul v. Davis, ${ }^{122}$ the court applied the "stigma-plus" test, affirming that reputation alone does not invoke the need for due process. Stigmatization of reputation during the loss of a right or status creates a person's right for due process. Defamation during a termination or denial of renewal satisfies the stigma-plus test. The court stated: "We think it self-evident that the allegation of a drinking problem made in connection with the refusal to renew a contract is one that might seriously damage his standing and associations within his community." ${ }^{23}$ The court ordered a hearing for Dennis to receive an opportunity to clear his name. While Dennis deserved a hearing, the court asserted the hearing was not an opportunity for Dennis to regain his previous employment with the district. "The district in this case was under no obligation to rehire Dennis, regardless of whether any or all reasons offered to explain his non-retention proved to be false." ${ }^{2124}$ Dennis only deserved the right to clear his name and possessed no entitlement to a new contract.

\footnotetext{
122424 U.S. 693, $709-710$ (1976). See Chapter 2, p. 54 for a further discussion on Paul v. Davis.

${ }^{123}$ Dennis, 577 F.2d at 343.

${ }^{124}$ Id. at 344.
} 
The courts afford a right to reputation to an employee when an employer's action causes harm to reputation during the course of termination. Furthermore, when an employer publicizes stigmatizing information about an employee, that employee possesses a legitimate claim under the protected right to reputation. An employer's comments, though, cannot harm an employee's protected right to reputation, once the employee's position ends. Moreover, when an employee fails to refute charges or when an employee's own actions enhance the public's knowledge of the stigmatizing information, an employee fails to prevail on a claim of loss of reputation.

\section{Procedural Due Process}

Procedural due process consists of "[ $t]$ he minimal requirements of notice and hearing guaranteed by the Due Process Clause of the Fifth and Fourteenth Amendments, especially if the deprivation of a life, liberty, or property interest may occur." ${ }^{125}$ When a deprivation of life, liberty, or property occurs, courts determine what process is due the claimant. Notice arises in two ways, the first encompassing notice of the charges and process for the hearing. Notice also relates to "rules of the game." This variety of notice involves knowing expectations in terms of behavior and conduct ahead of time, making rules understandable, clear, and, of particular importance to this study, not vague. For purposes of this study, the "rules of the game" was the only type of notice considered, when an employee claimed a deprivation of procedural due process as a result of employer action. ${ }^{126}$

The court resolved some of the identified cases involving off-duty conduct on the procedural due process issues of notice of charges and hearing. While these cases do not

\footnotetext{
${ }^{125}$ BLACK'S LAW DiCTIONARY, supra note 44 , at 406.

${ }^{126}$ See Chapter 2, p. 54 for further discussion on the right to procedural due process.
} 
involve the specific legal issue the researcher examined, the cases remain on-point to the research question and the researcher included their data in the overall results.

In theses cases involving notice and hearing employers prevailed fifteen times. ${ }^{127}$ Twelve cases were identified where employees prevailed on the procedural issues of notice and hearing. ${ }^{128}$

A review of the relevant case law identified fifty-three cases where the courts rendered opinions on the right to procedural due process. Of these cases, employers prevailed thirty-four times and employees prevailed nineteen times. The cases ranged from 1942 to 2004, and involved forty-three teachers, four administrators, three coaches, and three groups of employees. As a result of employer discipline for off-duty conduct, the employees either lost their position or faced suspension. Employees argued all but the right to freedom of religion in these cases. Employers defended their actions by asserting the following arguments: no deprivation of freedom of association, no deprivation of

\footnotetext{
${ }^{127}$ Fifteen of the due process cases where employers prevailed involved procedural issues of notice and hearing, as opposed to the due process issue of "rules of the game." See Appeal of Batrus, 26 A.2d 121 (Pa. Super. Ct. 1942); Coleman v. Reed, 147 F.3d 751 (8th Cir. 1998); Di Genova v. State Bd. of Educ., 288 P.2d 862 (Cal. 1955); Gish v. Bd. of Educ., 366 A.2d 1337 (N.J. 1976); Hankla v. Governing Bd., 120 Cal. Rptr. 827 (Cal. Ct. App. 1975); Hines v. Bd. of Educ., 492 F.Supp 469 (E.D. Ky. 1980); Kinniry v. Abington Sch. Dist., 673 A.2d 429 (Pa. Commw. Ct. 1996); Meinhold v. Clark County Sch. Dist., 506 P.2d 420 (Nev. 1973); Meredith v. Bd. of Educ., 130 N.E.2d 5 (Ill. App. Ct. 1955); Montefusco v. Nassau County, 39 F.Supp.2d 231 (E.D.N.Y. 1999); Purifoy v. State Bd. of Educ., 106 Cal. Rptr. 201 (Cal. Ct. App. 1973); Scott v. Bd. of Educ., 156 N.E.2d 1 (Ill. App. Ct. 1959); Shipley v. Salem Sch. Dist., 669 P.2d 1172 (Or. Ct. App. 1983); Vukadinovich v. Bd. of Sch. Tr., 978 F.2d 403 (7th Cir. 1992); and Williams v. Bd. of Pub. Instr., 311 So. 2 d 712 (Fla. Dist. Ct. App. 1975).

${ }^{128}$ Twelve of the due process cases where employees prevailed involved procedural issues of notice and hearing, as opposed to the due process issue of "rules of the game." See Bogart v. Unified Sch. Dist., 432 F.Supp. 895 (D. Kan. 1977); Bowalick v. Commw., 840 A.2d 519 (Pa. Commw. Ct. 2004); Brown v. Bathke, 566 F.2d 588 (8th Cir. 1977); City of Knoxville Bd. of Educ. v. Markelonis, 460 S.W.2d 362 (Tenn. Ct. App. 1970); Clark v. Sch. Bd., 596 So. 2 d 735 (Fla. Dist. Ct. App. 1992); Dennis v. S \& S Consolidated Rural High Sch. Dist., 577 F.2d 338 (5th Cir. 1978); Jackson v. El Dorado Sch. Dist., 48 S.W.3d 558 (Ark. Ct. App. 2001); Lindgren v. Bd. of Tr., 558 P.2d 468 (Mont. 1976); Rogliano v. Fayette County Bd. of Educ., 347 S.E.2d 220 (W. Va. 1986); Slater v. Pa. Dep't of Educ., 725 A.2d 1248 (Pa. Commw. Ct. 1999); Turk v. Franklin Special Sch. Dist., 640 S.W.2d 218 (Tenn. 1982); and Williams v. Sumter Sch. Dist., 255 F.Supp. 397 (D.S.C. 1966).
} 
right to free speech, due process already given, no process due, and no deprivation of right to equal protection. All thirteen types of off-duty conduct led to the adverse employment decision in these cases (see Table 7).

Table 7: Types of off-duty conduct in right to procedural due process cases by prevailing party.

\begin{tabular}{|c|c|c|c|}
\hline Type of Off-Duty Conduct & $\begin{array}{c}\text { Number of } \\
\text { Cases }\end{array}$ & $\begin{array}{c}\text { Employer } \\
\text { Prevails }\end{array}$ & $\begin{array}{c}\text { Employee } \\
\text { Prevails }\end{array}$ \\
\hline Affiliation & 5 & 3 & 2 \\
\hline Alcohol & 5 & 2 & 3 \\
\hline Drugs & 7 & 4 & 3 \\
\hline Fraudulent Behavior & 1 & 1 & \\
\hline Homosexuality & 3 & 1 & 2 \\
\hline Inappropriate Relationship w/Adult & 2 & 2 & \\
\hline Inappropriate Relationship w/Minor & 4 & 3 & 1 \\
\hline Marital Misbehavior & 2 & & 2 \\
\hline Out-of-Wedlock Pregnancy & 2 & & 2 \\
\hline Sexual Exhibitionism/Public Display & 3 & 3 & \\
\hline Theft/Robbery & 3 & 1 & 2 \\
\hline Other Criminal Conduct & 13 & 12 & 1 \\
\hline Other Non-Criminal Conduct & 3 & 2 & 1 \\
\hline 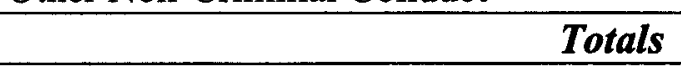 & 53 & 34 & 19 \\
\hline
\end{tabular}

Employer Prevails. ${ }^{129}$

Employees often claim a deprivation of procedural due process by arguing that state statutes used to justify employer actions lack clarity. Three such cases emerged from the research, two of which came in 1996. In the Missouri case, C.F.S. v. Mahan, ${ }^{130}$ a

\footnotetext{
${ }^{129}$ See Alford v. Ingram, 931 F.Supp. 768 (M.D. Ala. 1996); Baker v. Sch. Dist., 371 A.2d 1028 (Pa. Commw. Ct. 1977); Barringer v. Caldwell County Bd. of Educ., 473 N.E.2d 435 (N.C. Ct. App. 1996); C.F.S. v. Mahan, 934 S.W.2d 615 (Mo. Ct. App. 1996); Chicago Bd. of Educ. v. Payne, 430 N.E.2d 310 (Ill. App. Ct. 1981); Faxon v. Sch. Comm., 120 N.E.2d 772 (Mass. 1954); Governing Bd. v. Brennan, 95 Cal. Rptr. 712 (Cal. Ct. App. 1971); Hainline v. Bond, 824 P.2d 959 (Kan. 1992); Jefferson County Sch. Dist. v. Fair Dismissals Appeals Bd., 793 P.2d 888 (Or. Ct. App.1990); Jenkyns v. Bd. of Educ., 294 F.2d 269 (D.C. Cir. 1961); McCullough v. Ill. State Bd. of Educ., 562 N.E.2d 1233 (Ill. App. Ct. 1990); Pordum v. Bd. of Regents, 357 F.Supp. 222 (N.D.N.Y. 1973); Sarac v. State Bd. of Educ., 57 Cal. Rptr. 69 (Cal. Ct. App. 1967); Skripchuk v. Austin, 379 A.2d 1142 (Del. Super. Ct. 1977); Sullivan v. Meade Indep. Sch. Dist., 530 F.2d 799 (8th Cir. 1975); Tomerlin v. Dade County Sch. Bd., 318 So. 2 d 159 (Fla. Dist. Ct. App. 1975); and Wishart v. McDonald, 367 F.Supp. 530 (D. Mass. 1973).

${ }^{130}$ See 934 S.W.2d 615 (Mo. Ct. App. 1996).
} 
nontenured teacher claimed the school district violated his right to procedural due process. The employee, hereinafter referred to as C.F.S., held a prior coaching and teaching job in another Missouri school district. While working for that school district in 1993, police arrested C.F.S. after observing him exposing his genitals in a public restroom and making sexual overtures to an undercover officer. After an arrest for indecent exposure, he tendered his resignation. C.F.S. pled guilty to a criminal misdemeanor and faced a fine for his criminal activity.

C.F.S. applied for an available position with the City of St. Louis later in 1993. C.F.S. claimed he informed the principal during his interview about the prior misdemeanor, but C.F.S. testified he had no recollection of indicating any prior convictions on the employment application. He did not list the misdemeanor conviction on the application. After three months of employment, C.F.S. received notification of termination based on his prior conviction.

C.F.S. argued in court that district officials provided him no notice that a prior conviction could jeopardize his employment status. He claimed that the statute school officials used to sustain his termination only implicated conduct during the term of the employment and not prior conduct. The court, though, supported the action of the school district. The court stated: "It is difficult in statutes and regulations to foresee the varying situations which might be presented which might require action. The paramount interest is the welfare of the students, and the authority of the board should not be confined."131 The court found that school officials possessed good cause to base a termination on the prior conduct of C.F.S., even though the conduct occurred before his hiring. C.F.S. failed to convince the court that the school official violated his procedural due process rights.

${ }^{131}$ Id. at 619. 
The court concluded that a person participating in an act of public sexual display should know the conduct might cause concern for any public school employer.

Another 1996 case, Barringer v. Caldwell County Board of Education, ${ }^{132}$ involved a tenured teacher disciplined for his connection in a firearms incident off-duty. Barringer held a high school teaching position at the time of the incident. Barringer showed up at a local pool hall in the middle of the night carrying two loaded guns and additional ammunition. Barringer told customers in the pool hall he was looking for a friend. Police arrested Barringer and charged him with terrorizing the public and carrying a concealed weapon. Barringer pled guilty to the criminal charges and received a suspended sentence. School officials, citing his immoral conduct and unfitness to teach, began termination proceedings against Barringer.

Barringer sued the school district, arguing the unconstitutionality of the state statute defining immorality. Claiming the statute was unclear and vague, Barringer insisted he did not know his conduct jeopardized his teaching position. The court, though, found Barringer's claim ineffective. The court, relying on previous North Carolina judicial precedent, stated: "terminology such as "good moral character" has been so extensively used as a standard that its long usage and the case law surrounding that usage have given the term well-defined contours which make it a constitutionally appropriate standard."133 The court asserted that a statute fails a vagueness claim when a "reasonable person" knows what conduct was proscribed. ${ }^{134}$ The court found the statute provided adequate notice to Barringer, as well as any other public school employee, regarding immoral conduct in terms of maintaining one's fitness to teach.

\footnotetext{
${ }^{132} 473$ N.E.2d 435 (N.C. Ct. App. 1996).

${ }^{133}$ In re Willis, 288 N.C. $1,11$.

${ }^{134}$ Barringer, 473 N.E.2d at 439.
} 
Twenty years prior to C.F.S. and Barringer, the case of Tomerlin v. Dade County School Board ${ }^{135}$ involved a similar employee argument regarding vagueness of a state statute. Tomerlin, a male elementary school teacher, possessed an unblemished teaching record. School officials became aware that Tomerlin had been sexually abusing his nineyear-old stepdaughter. After an immediate dismissal from his position on grounds of immorality, Tomerlin appealed the dismissal to the state board. The state board concurred with the termination and Tomerlin brought suit against the school board.

Tomerlin claimed the statute that school officials relied on failed to provide him adequate notice of what conduct constituted immorality. This court found the statute to regulate clearly the conduct of a person in the teaching profession. "The term immorality is sufficiently clear to designate actionable misconduct." ${ }^{, 136}$ Furthermore, this court expressed that while the statute did not define every single immoral act justifying a disciplinary action by an employer, "any reasonable person should know that the act performed by Tomerlin was immoral, and was prohibited by the statute." ${ }^{137}$ Tomerlin did not prevail on his claim that school officials failed to provide him adequate notice of the rules and no deprivation of Tomerlin's procedural due process rights occurred by the actions of his employer.

While employees often argue vagueness when claiming a right to procedural due process, another argument employees occasionally make in adverse employment decisions involves the issue of remediation. Employees assert that their conduct or behavior was remediable, but no one informed them to take planned, corrective action.

\footnotetext{
${ }^{135} 318$ So. 2d 159 (Fla. Dist. Ct. App. 1975).

${ }^{136} \mathrm{Id}$. at 160.

${ }^{137} \mathrm{Id}$.
} 
Two cases, McCullough v. Illinois State Board of Education ${ }^{138}$ and Sullivan v. Meade Independent School District, ${ }^{139}$ illustrate this employee argument.

In a 1990 Illinois case, a tenured teacher claimed that school officials failed to provide him notice of the rules of the game. ${ }^{140}$ McCullough's off-duty conduct involved a failure to file taxes, and he faced three felony counts for tax evasion. Furthermore, McCullough failed to appear at his arraignment, which led to his arrest. At his criminal trial, McCullough became very unruly and court officials took him into custody. The judge ordered him placed in a psychiatric facility. Even though McCullough apologized to the court, the media widely exposed the events surrounding his criminal trial. Many members of the school community knew about his conduct in the courtroom and his mandatory admission to a psychiatric facility. School officials dismissed McCullough on grounds of incompetence, negligence, and immorality. At his school board hearing, the evidence suggested McCullough's conduct was not remediable.

McCullough claimed that school officials failed to provide him adequate notice by erring when finding he was unable to remediate his conduct. McCullough alleged that school officials provided no warning to him to clear up the criminal matter quietly or jeopardize his position. The court found his argument moot. "Regardless of whether the conduct was remediable, it was certainly not remediable after plaintiff was convicted and the conviction and plaintiff's attendant conduct was well publicized."141 School officials prevailed in McCullough's claim of violation of procedural due process.

\footnotetext{
138562 N.E.2d 1233 (IIl. App. Ct. 1990).

139530 F.2d 799 (8th Cir. 1975).

${ }^{140} \mathrm{McCullough,} 562$ N.E.2d at 1233.

${ }^{141}$ Id. at 1237.
} 
Fifteen years prior to $\mathrm{McC}$ Cullough, a South Dakota case involved a similar judicial outcome. In Sullivan, a female teacher lost her teaching position because of cohabitating with a man outside of marriage. Sullivan did nothing to conceal her living arrangements from students, parents, and other employees within the school community. The principal approached Sullivan several times to discuss the cohabitation issue. Sullivan, declaring the matter private, refused to enter into a discussion with the principal. The principal advised Sullivan the continuation of her living arrangements jeopardized her job retention. School officials provided a hearing for Sullivan. During the hearing board members asked Sullivan to consider having the man live elsewhere, but she refused that option. Board members dismissed Sullivan, citing that many in the community considered her conduct grossly immoral.

Sullivan sued the school board claiming school officials failed to provide her proper notice of the rules. The court found Sullivan's claim invalid, ruling that school officials went beyond minimal efforts to provide Sullivan notice that her cohabitation jeopardized her position. "The record shows that when school officials became aware of Ms.

Sullivan's conduct, they contacted her, asked her about the facts, and suggested a compromise solution."142 Board members even made a final effort to convince Sullivan to change her living arrangements prior to rendering their termination decision. Sullivan received more than sufficient notice of rules of the game. The court found that while Sullivan possessed a constitutional right to follow her own lifestyle, the school board members acted in good faith toward her and with concern for her procedural due process rights while pursuing disciplinary measures.

${ }^{142}$ Sullivan, 530 F.2d at 807. 
Sometimes employees argue vagueness in regard to the grounds used by employers to make disciplinary decisions. In Governing Board v. Brennan, ${ }^{143}$ a nontenured teacher lost her teaching job when school officials became aware of her recreational use of drugs. School officials gained knowledge of Brennan's drug use via the media. Apparently, in an attempt to assist a friend arrested and charged with marijuana possession, Brennan wrote an affidavit of support to submit to the court regarding her long and beneficial use of marijuana. Her affidavit incurred a lot of media attention and numerous students and employees found out that Brennan used marijuana. School officials immediately suspended her and moved for her dismissal on grounds of immorality.

Brennan brought suit against school officials in an attempt to retain her employment with the district. She argued that school officials failed to provide minimal notice as required by procedural due process. She claimed the term "immoral conduct" was unconstitutionally vague. The court failed to find Brennan's argument persuasive, indicating that terms such as "immoral conduct" cover a wide area of conduct. ${ }^{144}$ The court further indicated that any reasonable person knows that the affidavit, indicating an admission of perpetual violation of California laws, was conduct deserving an "immoral" classification. ${ }^{145}$ School officials provided Brennan the minimum requirements of notice, and therefore, satisfied her constitutionally protected rights afforded under procedural due process.

Employee claims of procedural due process rights based on vagueness challenges failed when courts found that a reasonable person would know the conduct was

\footnotetext{
${ }^{143} 95$ Cal. Rptr. 712 (Cal. Ct. App. 1971).

${ }^{144}$ Id. at 714.

${ }^{145}$ Id.
} 
proscribed. Additionally, courts found employee claims invalid if the conduct in question was not remediable.

Employee Prevails. ${ }^{146}$

When employees believe that state statutes are vague and lacking clarity, they often claim employer actions based on those statutes deprived them of a constitutionally protected right of procedural due process. Two cases successfully established this employee claim.

In Burton v. Cascade School District Union High School, ${ }^{147}$ a nontenured teacher lost her position after school officials became aware of her homosexual lifestyle. The school principal, who received information from the mother of a student that Burton was gay, confronted Burton. Burton acknowledged that she practiced homosexuality as a lifestyle choice. The school board terminated Burton on grounds of immorality, citing her homosexual lifestyle.

Burton sued, claiming the statute the board relied on to sustain her termination was unconstitutionally vague. The court agreed to the vagueness of the statute defining "immorality" and found the statute violated Burton's due process rights. The court, though, only awarded Burton damages amounting to the balance of salary lost plus one half of the salary for the next school year. The court refused to consider reinstatement for Burton. While Burton won the battle regarding her lost pay, she failed to prevail on

\footnotetext{
${ }^{146}$ See Ala. Educ. Ass'n v. Wallace, 362 F.Supp. 682 (M.D. Ala. 1973); Brownsville Area Sch. Dist. $v$. Alberts, 260 A.2d 765 (Pa. 1970); Burton v. Cascade Sch. Dist., 512 F.2d. 850 (9th Cir. 1975); Nat'l Gay Task Force v. Bd. of Educ., 729 F.2d 1270 (10th Cir. 1984); Overton v. Goldsboro City Bd. of Educ., 283 S.E.2d 495 (N.C. 1981); Reinhardt v. Bd. of Educ., 311 N.E.2d 710 (IIl. App. Ct. 1974); and Thompson v. Southwest Sch. Dist., 483 F.Supp. 1170 (W.D. Mo. 1980).

${ }^{147} 512$ F.2d. 850 (9th Cir. 1975).
} 
reinstatement. Her off-duty conduct, practicing a homosexual lifestyle, lost her the teaching position.

In 1980, a similar judicial outcome came in Thompson v. Southwest School District. ${ }^{148}$ Thompson, a tenured teacher of eleven years for the school district, chose to live with a man but not to marry him. School officials asked Thompson to sign a statement on a performance evaluation verifying her cohabitation arrangements. She signed the statement but later requested to remove the statement from her evaluation. School officials denied this request and urged her to resign. School officials further indicated they would not mention the cohabitation in any future employment reference, but only if Thompson resigned. Thompson married the man she lived with, yet the school district still suspended her employment. School board members based their suspension decision on grounds of "immoral conduct."

Thompson brought suit against the school district in federal court claiming the statute justifying the suspension decision was constitutionally void for vagueness. Statutes, she argued, must contain provision of sufficiently clear notice and a standard of what conduct might incur judgment. "Judged by this standard, this Court has serious doubts as to whether the term "immoral conduct" when considered in the abstract provides fair warning of the proscribed conduct." ${ }^{\text {149 }}$ Thompson possessed no foreknowledge of what type of conduct constituted "immoral conduct," and more specifically that cohabitating with a man outside of marriage constituted "immoral conduct" in the eyes of the school officials. The court further stated: "A statute so broad makes those charged with its enforcement the arbiters of morality for the entire community. In doing so, it subjects the

\footnotetext{
148483 F.Supp. 1170 (W.D. Mo. 1980).

${ }^{149}$ Id. at 1179.
} 
livelihood of every teacher in the state to the irrationality and irregularity of such judgments." 150 Failure to provide an employee with notice of "rules of the game" represents a violation of procedural due process rights. Thompson possessed no warning of prohibited conduct and the court supported her claim against the school district.

Employees occasionally asserted that their conduct or behavior was remediable, but no one informed them to take corrective action. In these instances, employees argue violation of the constitutionally protected right to procedural due process.

This argument appears in Reinhardt v. Board of Education. ${ }^{151}$ Reinhardt got married during her eighth month of pregnancy and school officials granted her maternity leave. While on maternity leave, the superintendent encouraged Reinhardt to resign. She submitted a letter of resignation but withdrew the letter two days later. The school board then proceeded to terminate her on grounds of immorality, as Reinhardt's behavior lacked remediation.

Reinhardt brought suit against the school district claiming violation of her due process rights. The court favored Reinhardt's claim indicating the school board never made a determination regarding the non-remedial nature of Reinhardt's conduct. Therefore, Reinhardt never received any notice about what changes needed to occur. In order to show that the situation was not remediable, the court expected the school board to indicate damage occurred to the school environment. "The board discloses no injury to the students, faculty, or school.... There is no evidence that her teaching ability was

\footnotetext{
${ }^{150} \mathrm{Id}$.

${ }^{151}$ Reinhardt v. Bd. of Educ., 311 N.E.2d 710 (I1l. App. Ct. 1974).
} 
affected in any manner, and no evidence that the standing of the school as education institution was in any manner affected by [Reinhardt's] action."152

Furthermore, the court held that the school board's failure to provide evidence that Reinhardt's behavior harmed the school community gave sanction to the practice of arbitrary dismissals of any employee. "Immorality ... is sufficient cause only where the record shows harm.... Otherwise we would be subjecting teachers to infinitely variable definitions of morality." 153 Reinhardt received no notice of what she needed to remediate in order to retain her position. Therefore, the court found that school officials failed to provide Reinhardt with adequate due process of law.

Occasionally, employees claim deprivation of procedural due process when employers fail to provide basic information about a rule or policy, especially when the rule or policy affects job retention. Such a case arose in Overton v. Goldsboro City Board of Education, ${ }^{154}$ where the Supreme Court of North Carolina heard a case regarding a claimed of deprivation of the right to procedural due process. After a felony indictment on drug charges, Overton chose to meet with the superintendent and inform him of the indictment. He requested time off without pay and the superintendent encouraged Overton to stay away until the criminal process ended. School officials moved to terminate Overton and requested his resignation. Overton then submitted a written request to the superintendent for time off without pay, but no willingness to resign his position. The board members suspended Overton without pay and the termination process ensued. Board members based their decision on a charge of neglect of duty, as Overton

\footnotetext{
${ }^{152} I d$. at 712.

${ }^{153} \mathrm{Id}$. at 713 .

${ }^{154} 283$ S.E.2d 495 (N.C. 1981$)$.
} 
refused to return to his position. At no time did the superintendent specifically state to Overton that a failure to return to work could amount to a neglect of duty charge.

This court defined neglect of duty as a "failure to perform some duty imposed by contract or law." 155 Failing to report to work clearly falls within this definition. The court, though, declared that Overton's employer failed to let him know he needed to return to work. Overton made the effort to meet with the superintendent and to request the time away from his position. Furthermore, the superintendent indicated Overton should stay away. "Superintendent Johnson never instructed plaintiff to return to school or indicated that his absence could give the Board cause to dismiss him."156 The court assumed Overton's compliance had he known this expectation. The court found Overton's right to procedural due process violated by the superintendent's failure to inform him of the expectation he return to work.

Another case where an employer failed to provide "notice of the rules" occurred in 1970. In Brownsville Area School District v. Alberts, ${ }^{157}$ possessing a second job caused school officials to discipline an assistant school principal. Alberts spent one summer working for a federally funded Head Start program and received compensation for his work. He also maintained his administrative responsibilities with the district and received pay during the same summer. Alberts claimed he worked approximately seven hours a day for the school district and four hours with the Head Start program. In the fall of the school year, the superintendent suspended Alberts on grounds of incompetence and negligence, as well as immorality. The superintendent indicated Alberts improperly

\footnotetext{
${ }^{155}$ Id. at 498.

${ }^{156} \mathrm{Id}$. at 499.

${ }^{157} 260$ A.2d 765 (Pa. 1970).
} 
received compensation from Head Start and further failed to provide copies of payroll documentation to the district.

Alberts brought a procedural due process claim against the school district, citing a failure to notify him of rules. Alberts claimed district officials never requested him to provide the payroll documentation. The court agreed with Alberts, finding the superintendent testified only "that [Alberts] had failed to provide the information in question, not that he had refused to do so." ${ }^{\text {158 }}$ Alberts would have complied had school officials requested the payroll information. The school district could not hold Alberts responsible for an unknown requirement. Alberts prevailed on his deprivation claim in regard to the constitutionally protected right to procedural due process.

Courts afford protection to employees' procedural due process rights in cases involving off-duty conduct when employers fail to provide notice of the rules. Employers cannot hold employees accountable to a vague or unclear statute or rule, simply because the employer chooses to discipline. Employees must know what is expected of their conduct, and the courts declare this right to know applies to off-duty conduct.

\section{Substantive Due Process}

Substantive due process is "[t]he doctrine that the Due Process Clause of the Fifth and Fourteenth Amendments require [laws, policies, and decisions] to be fair and reasonable in content and to further a government objective." ${ }^{159}$ Substantive due process relates to the "what" government does or "why" government acts. ${ }^{160}$

The researcher identified sixty-nine cases involving the right to substantive due process. Employers prevailed in forty-two cases, while employees prevailed in the

\footnotetext{
${ }^{158} I d$. at 768.

${ }^{159}$ BLACK'S LAW DiCtionaRY, supra note 44 , at 406.

${ }^{160}$ See Chapter 2, p. 56 for further discussion on the right to substantive due process.
} 
remaining twenty-seven. These cases ranged from 1898-2003 and involved mostly teachers, with the exception of two administrators, three coaches, one staff person, and one group of other employees. The group of employees lost their jobs, faced suspension, or received a negative letter in their personnel file.

Employees in these cases did not claim a right to freedom of religion or a right to reputation when bringing suit against employers. Employers responded to these lawsuits by arguing no deprivation of substantive due process. In justifying their adverse decisions, employers argued all rights with the exception of freedom of religion. The right to substantive due process cases involved twelve of the identified types of off-duty conduct (see Table 8).

Table 8: Types of off-duty conduct in right to substantive due process cases by prevailing party.

\begin{tabular}{|c|c|c|c|}
\hline Type of Off-Duty Conduct & $\begin{array}{l}\text { Number of } \\
\text { Cases }\end{array}$ & $\begin{array}{c}\text { Employer } \\
\text { Prevails }\end{array}$ & $\begin{array}{c}\text { Employee } \\
\text { Prevails }\end{array}$ \\
\hline Affiliation & 4 & 1 & 3 \\
\hline Alcohol & 3 & 2 & 1 \\
\hline Drugs & 21 & 12 & 9 \\
\hline Fraudulent Behavior & 4 & 4 & \\
\hline Homosexuality & 2 & 1 & 1 \\
\hline Inappropriate Relationship w/Adult & 6 & 3 & 3 \\
\hline Inappropriate Relationship w/Minor & 4 & 3 & 1 \\
\hline Marital Misbehavior & 2 & 1 & 1 \\
\hline Out-of-Wedlock Pregnancy & 2 & & 2 \\
\hline Sexual Exhibitionism/Public Display & 5 & 3 & 2 \\
\hline Theft/Robbery & 6 & 5 & 1 \\
\hline Other Criminal Conduct & 10 & 7 & 3 \\
\hline Totals & 69 & 42 & 27 \\
\hline
\end{tabular}

The researcher identified cases from each decade that indicated instances where courts found employer actions fair and reasonable, as well as instances where the courts found the reverse. Unlike the other legal rights argued in the off-duty cases, the right to 
substantive due process remains fairly straightforward. Either a government action

involves fairness and reason, or it does not. The nuances of argument that the other legal rights encounter do not seem as apparent in these cases.

Employer Prevails. ${ }^{161}$

The responsibility of teachers to conduct their lives under greater social scrutiny than other professionals became apparent throughout a review of the cases. Teachers, though, often argue that when government scrutiny leads to discipline for conduct occurring offduty, a deprivation of their substantive due process right occurs. A 1966 Arizona case clearly illustrated this point. ${ }^{162}$ Williams, along with his female companion, encountered some trouble at a local bar. Apparently they played pool and drank beer with some other bar patrons who later accosted them outside the bar. Williams went back in the bar,

${ }^{161}$ See Adams v. State of Fla., Prof'l Practices Council, 406 So. $2 d 1170$ (Fla. Dist. Ct. App. 1981); Adkins v. W. Va. Dep't of Educ., 556 S.E.2d 72 (W. Va. 2001); Bertrand v. N.M. State Bd. of Educ., 544 P.2d 1176 (N.M. Ct. App. 1976); Bd. of Dirs. v. Davies, 489 N.W.2d 19 (Iowa 1992); Bd. of Educ. v. Adelman, 423 N.E.2d 254 (Ill. App. Ct. 1981); Bd. of Educ. v. Calderon, 110 Cal. Rptr. 916 (Cal. Ct. App. 1974); Bd. of Educ. v. Wilkinson, 270 P.2d 82 (Cal. Dist. Ct. App. 1954); Crumpler v. State Bd. of Educ., 594 N.E.2d 1071 (Ohio Ct. App. 1991); Denton v. South Kitsap Sch. Dist., 516 P.2d 1080 (Wash. Ct. App. 1973); Deshields v. Chester-Upland Sch. Dist., 505 A.2d 1080 (Pa. Commw. Ct. 1986); Dominy v. Mays, 257 S.E.2d 317 (Ga. Ct. App. 1979); Dupree v. Sch. Comm. of Boston, 446 N.E.2d 1099 (Mass. App. Ct. 1983); Ellis v. Ambach, 508 N.Y.S.2d 624 (N.Y. App. Div. 1986); Feagin v. Everett, 652 S.W.2d 839 (Ark Ct. App. 1983); Freeman v. Town of Bourne, 49 N.E. 435 (Mass. 1898); Gaylord v. Tacoma Sch. Dist., 559 P.2d 1340 (Wash. 1977); Hamm v. Poplar Bluff Sch. Dist., 955 S.W.2d 27 (Mo. Ct. App. 1997); Hoffman v. State Bd. of Educ., 763 N.E.2d 210 (Ohio Ct. App. 2001); Homer v. Commonwealth, 458 A.2d 1059 (Pa. Commw. Ct. 1983); In re Bay, 378 P.2d 558 (Or. 1963); In re Thomas, 926 S.W.2d 163 (Mo. Ct. App. 1996); Jefferson Union High Sch. v. Jones, 100 Cal. Rptr. 73 (Cal. Ct. App. 1972); Kenai Peninsula Borough Bd. of Educ. v. Brown, 691 P.2d 1034 (Alaska 1984); Lang v. Lee, 639 S.W.2d 111 (Mo. Ct. App. 1982); Lesley v. Oxford Area Sch. Dist., 420 A.2d 764 (Pa. Commw. Ct. 1980); Martin v. Santa Clara Unified Sch. Dist., 125 Cal. Rptr. 2d (Cal. Ct. App. 2002); Matter of Shelton, 408 N.W.2d 594 (Minn. Ct. App. 1987); Moser v. State Bd. of Educ., 101 Cal. Rptr. 86 (Cal. Ct. App. 1972); Newchurch v. Louisiana State Bd., 713 So. 2d 1269 (La. Ct. App. 1998); Panzella v. River Trails Sch. Dist., 729 N.E.2d 954 (Ill. App. Ct. 2000); Perryman v. Sch. Comm., 458 N.E.2d 748 (Mass. App. Ct. 1983); Purvis v. Marion County Sch. Bd., 766 So. 2d 492 Fla. Dist. Ct. App. 2000); Riforgiato v. Bd. of Educ., 448 N.Y.S.2d 74 (N.Y. App. Div. 1982); Satterfield v. Bd. of Educ., 556 N.W.2d 888 (Mich. Ct. App. 1996); Startzel v. Commonwealth, 562 A.2d 1005 (Pa. Commw. Ct. 1989); Stelzer v. State Bd. of Educ., 595 N.E.2d 489 (Ohio Ct. App. 1991); Walton v. Turlington, 444 So. $2 d 1082$ (Fla. Dist. Ct. App. 1984); Watson v. State Bd. of Educ., 90 Cal. Rptr. 468 (Cal. Ct. App. 1971); Williams v. Sch. Dist., 417 P.2d 376 (Ariz. Ct. App. 1966); Woo v. Putnam County Bd. of Educ., 504 S.E.2d 644 (W. Va. 1998); Yanzick v. Sch. Dist., 641 P.2d 431 (Mont. 1982); and Zelno v. Lincoln Intermediate Unit 12 Bd. of Dir., 786 A.2d 1022 (Pa. Commw. Ct. 2002). 162 Williams v. Sch. Dist., 417 P.2d 376 (Ariz. Ct. App. 1966). 
secured a pistol from the bartender, and then waved the pistol at his assailants. Police arrived and arrested Williams, charging him with disturbing the peace, being under the influence, and displaying a gun. After he pled guilty to the charges, school officials terminated Williams from his teaching position.

Williams, finding his termination based on off-duty conduct arbitrary, brought suit against school officials. The court, though, found the school officials made a legal decision in terminating Williams. The court considered the school's employee manual which stated: "The teaching profession occupies a position of public trust not only involving the teacher's personal conduct, but also the interaction of the school and the community." ${ }^{163}$ Furthermore, the school policy required teachers to "adhere to any reasonable pattern of behavior accepted by the community."164 The court declared that Williams' conduct that led to an arrest and guilty plea did not encompass a reasonable pattern of behavior. Furthermore, the court maintained that school officials possessed just cause for termination that was not arbitrary. Williams' claim failed becuase no deprivation of his substantive due process rights occurred.

In Denton v. South Kitsap School District, ${ }^{165}$ another case involving a deprivation of substantive due process rights surfaced. Denton, a male junior high school teacher, began a relationship with a high school student, as a result of a friendship he held with her parents. The high school student had never been Denton's student or a student in the school where he taught. Denton received permission from the girl's parents to pursue the relationship. School officials got involved when the girl became pregnant. Denton

\footnotetext{
${ }^{163} \mathrm{Id}$. at 377 .

${ }^{164} \mathrm{Id}$.

${ }^{165} 516$ P.2d 1080 (Wash. Ct. App. 1973).
} 
married the girl, with the blessings of her parents. School officials, though, gave Denton a letter of termination.

Denton claimed the termination violated his right to substantive due process, as his relationship and subsequent marriage bore no relationship to his position. The court, though, disagreed, stating: "It is difficult to conceive of circumstances which would more clearly justify the action of the school board than the sexual misconduct of a teacher with a minor student in the district."166

Denton, relying on the Morrison precedent, ${ }^{167}$ argued that a discharge based on sexual misconduct retains validity only when school officials show the conduct caused an adverse impact on the teacher's effectiveness. The court, however, declined to set such a requirement because the sexual misconduct involved a teacher and a minor student. "The school board may properly conclude in such a situation that the conduct is inherently harmful to the teacher-student relation, and thus to the school district."168 The court found the school board's action more than justified and dismissed Denton's claimed deprivation of his right to substantive due process.

Employers clearly possess the right to consider criminal actions when determining adverse employment decisions. Even when criminal courts find an employee not guilty of charges, an employer may still discipline based on the off-duty conduct that led to the initial criminal charges Thirteen years after Denton another public school employee argued the unfairness of his termination. In the matter of DeShields v. Chester-Upland School District, ${ }^{169}$ school officials suspended a school custodian after his arrest for

\footnotetext{
${ }^{166} I d$. at 1082.

${ }^{167} 461$ P.2d 375 (Cal. 1969). See Chapter 2, p. 43 and Chapter 4, p.85 for further discussion on Morrison.

${ }^{168}$ Denton, 516 P.2d at 1082.

169505 A.2d 1080 (Pa. Commw. Ct. 1986).
} 
possession and intent to deliver illegal substances. Subsequent to the suspension, school officials provided DeShields with a hearing. At the hearing, police testified that DeShields possessed more than 100 grams of marijuana at the time of his arrest. Even though the court dropped all criminal charges due to a successful suppression motion related to the marijuana, school officials decided to terminate DeShields for immoral conduct.

DeShields argued that school officials violated his substantive due process rights when they based his termination on information a criminal court suppressed. The court, though, maintained that the school officials' reliance on the evidence of the 100 grams of marijuana did not violate DeShields' rights. The evidence, while not available for the criminal court to use for a conviction, became fair game for school officials to consider in their decision related to DeShields' employment status. The court further indicated that failure to consider the evidence would amount to carelessness on the part of the district. "The school district's interest in protecting its students and insuring a safe school environment would be jeopardized by the exclusion of evidence concerning serious misconduct by its employees. ... the evidence was properly admitted despite the fact that it had been illegally seized."170

In addition, DeShields put forward another argument to support his claim of deprivation. He claimed that his conduct failed to rise to improper conduct, in that his position as custodian offered little to no contact with students. The court found this argument without merit. The school district possessed a rational justification for terminating DeShields for his involvement with illegal substances. The court further stated: "There is no question that a school custodian would have ample access to the

${ }^{170}$ Id. at 1083. 
student body, or a certain segment of a student body, if he had a mind toward that purpose." ${ }^{\prime 171}$ The court found the school officials' action of terminating DeShields fair. Therefore, no deprivation of his substantive due process rights occurred.

Moving into the 1990's, employees still questioned the discipline actions they received from employers based on their off-duty conduct. In Crumpler v. State Board of Education, ${ }^{172}$ a tenured teacher engaged in repeated criminal acts of theft. Crumpler taught in a special education program in a state group home for profoundly retarded school-aged males. She stole money and drugs from the group home. After pleading guilty to two counts of criminal mischief, the court sentenced her to six months in jail. Crumpler received probation when she voluntarily entered a drug treatment program. She did resign her state-appointed teaching position at the group home.

When Crumpler completed her in-patient treatment, the state board held a hearing on whether to suspend or revoke her teaching license. The hearing officer, convinced by Crumpler's voluntary recovery efforts, recommended no discipline. During the weekend following the hearing, Crumpler sustained an injury warranting prescription pain medicine. Crumpler failed to inform the doctor of her chemical dependency, accepted the prescription, and relapsed into a pattern of drug addiction. This pattern concluded with Crumpler's arrest for attempting to alter the Darvocet prescription from 30 to 130 tablets. The state board held another hearing, and this time the hearing officer recommended revocation of Crumpler's teaching license.

Crumpler argued the state board violated her right to substantive due process because evidence used by the state board officials lacked legal substance. The court first

\footnotetext{
171 Id. at 1084.

172594 N.E.2d 1071 (Ohio Ct. App. 1991).
} 
considered what grounds the state board members possessed on which to base revocation decisions. The court found that state law allowed board officials to consider various criminal convictions when making revocation decisions, including the illegal processing of drug documents. Additionally, the court studied the pattern of Crumpler's conduct. "The severity of conduct that it presented was sufficient to show grounds for revocation pursuant to state law as it involved intemperate and immoral conduct unbecoming to her position." 173 Based on the pattern and severity of Crumpler's behavior, the state board acted on substantial evidence when determining to revoke her license. Crumpler suffered no deprivation of substantive due process rights.

Employees today still must remain conscious of their behavior, as the basis of the role model argument continues to persuade judges to find for the employer. For example, a Florida case in 2000, Purvis v. Marion County School Board, ${ }^{174}$ involved a teacher and coach claiming a deprivation of his constitutionally protected right to substantive due process. Purvis, during his first year assigned to a district high school, got entangled in an altercation with his girlfriend at a local nightclub that led to his arrest for domestic violence battery and resisting an officer with violence. Purvis faced a jury trial on the charges and received acquittal on all counts. Even so, school officials suspended Purvis and held a hearing. At the hearing, Purvis' principal testified that he previously warned Purvis not to go to the "Shark Attack" nightclub. The principal also indicated that Purvis knew that school officials expected him to act as a role model for students. The principal testified Purvis' that conduct made him a poor role model for students he taught and

\footnotetext{
${ }^{173}$ Id. at 1073-1074.

174766 So. 2d 492 (Fla. Dist. Ct. App. 2000).
} 
coached. Purvis lost his position with the district based on a charge of misconduct in office and impaired effectiveness.

Purvis insisted that school officials unfairly considered his off-duty conduct when making their adverse decision. The court, though, did not find the issue of "where" the conduct occurred as important as the conduct itself, in regard to Purvis' continued effectiveness as a teacher. The court stated, "We do not think the issue of "impaired effectiveness" turns on whether the misconduct occurred on school grounds."175 Furthermore, the court gave deference to the school board's decision: "The courts should defer to the agency unless their construction amounts to an unreasonable interpretation, or is clearly erroneous." ${ }^{\prime 176}$ The court found that district officials made a fair decision and therefore did not violate Purvis' constitutional right to substantive due process.

Again, in 2001, courts favored an employer asserting the fairness of disciplining an employee for off-duty conduct. A Pennsylvania teacher lodged a constitutional claim of right to substantive due process against her employer in $2001 .{ }^{177}$ Zelno taught in an alternative education program housed in a drug and alcohol rehabilitation treatment center for court-adjudicated males. In 1999, she pled guilty to a DUI charge and driving without a license. Court officials suspended her license after a prior DUI charge. At this point, Zelno possessed a total of five alcohol related charges. Zelno's jail time for these last charges could be served on consecutive weekends during the school year, if she agreed to remain incarcerated over the summer. This sentence ran concurrently with her previous sentence. School officials initiated dismissal proceedings against Zelno citing her behavior constituted immorality.

\footnotetext{
175 Id. at 498.

${ }^{176}$ Id. at 499.

${ }^{177}$ Zelno v. Lincoln Intermediate Unit 12 Bd. of Dirs., 786 A.2d 1022 (Pa. Commw. Ct. 2001).
} 
Zelno argued that her alcohol related conduct did not rise to a level of immorality. The court, though, failed to find her argument persuasive. A repeated pattern emerged from Zelno's conduct making her conduct tantamount to immorality. The court stated, "[Her conduct] indicates not a single act of misjudgment, but rather a pattern of conduct that is not only damaging to her but also puts the public in serious danger."178

Zelno then argued that even if her conduct was immoral, school officials failed to show evidence her conduct affected her students or any other member of the school community. However, the court did not need evidence that Zelno's conduct harmed any particular student or students. "Showing that her conduct impacted on a specific student or her ability to teach is not relevant to show immorality; proof of the conduct makes her a bad role model." ${ }^{179}$ Furthermore, the court considered that Zelno's position involved teaching students who dealt with severe alcohol and drug problems. She could not expect that school officials would overlook her alcohol related conduct. School officials fairly assessed the situation and found Zelno's conduct a bad example for her students. Furthermore, school officials based the termination decision on clear grounds of immorality. Zelno's deprivation claim failed.

${ }^{178} I d$. at 1025 .
${ }^{179} I d$. at 1026. 
Employee Prevails. ${ }^{180}$

While employers prevail more often in the cases involving substantive due process, courts determined in several instances that the discipline meted out for off-duty conduct was unfair and unreasonable. While not directly contradicting an employer's right to punish employees for off-duty conduct, courts examine disciplinary actions to ensure they meet the minimum requirements of substantive due process.

For example, a 1968 Ohio case, Hale v. Board of Education, ${ }^{181}$ involved a teacher's claim of deprivation of the right to substantive due process. Hale, who taught middle school, hit a parked car while intoxicated. He left the scene of the accident without filing a report. Police later arrested Hale and charged him with leaving the scene of an accident. Hale eventually pled no contest to the charge, received a suspended ten-day sentence, and paid a fifty-dollar fine. Officials of the school district moved to terminate Hale on grounds of immorality and gross inefficiency in the classroom.

Hale brought suit against school officials, claiming a lack of evidence to support the grounds for termination. The court favored Hale's contention, finding school officials

\footnotetext{
${ }^{180}$ See Ala. Educ. Ass'n v. Wallace, 362 F.Supp. 682 (M.D. Ala. 1973); Baker v. Sch. Bd., 450 So. 2d 1194 (Fla. Dist. Ct. App. 1984); Bd. of Educ. v. Jack M., 566 P.2d 602 (Cal. 1977); Board of Pub. Educ. Sch. Dist. v. Intille, 163 A.2d 420 (Pa. 1960); Bd. of Tr. v. Judge, 123 Cal. Rptr. 830 (Cal. Dist. Ct. App. 1975); Cameron v. Bd. of Educ., 795 F.Supp. 228 (S.D. Ohio 1991); Comings v. State Bd. of Educ., 100 Cal. Rptr. 73 (Cal. Ct. App. 1972); Erb v. Iowa State Bd. of Pub. Instr., 216 N.W.2d 339 (Iowa 1974); Fielder v. Bd. of Dirs., 662 N.W.2d 371 (Iowa Ct. App. 2003); Fischler v. Askew, 349 So. 2 d 227 (Fla. Dist. Ct. App. 1977); Fisher v. Snyder, 476 F.2d 375 (8th Cir. 1973); Ford v. Bay County Sch. Bd., 246 So. 2d 119 (Fla. Dist. Ct. App. 1970); Fountain v. State Bd. of Educ., 320 P.2d 899 (Cal. Dist. Ct. App. 1958); Garcia v. State Bd. of Educ., 694 P.2d 1371 (N.M. Ct. App. 1984); Hale v. Bd. of Educ., 234 N.E.2d 583 (Ohio 1968); Harmon v. Mifflin County Sch. Dist., 713 A.2d 620 (Pa. 1998); Hoagland v. Mount Vernon Sch. Dist., 623 P.2d 1156 (Wash. 1981); In re Termination of Kibbe, 996 P.2d 419 (N.M. 2000); Lowenstein $v$. Newark Bd. of Educ., 171 A.2d 265 (N.J. 1961); McNeill v. Pinellas County Sch. Bd., 678 So. 2d 476 (Fla. Dist. Ct. App. 1996); N.M. State Bd. of Educ. v. Stoudt, 571 P.2d 1186 (N.M. 1977); Ott v. Bd. of Educ., 389 A.2d 1001 (N.J. App. Div. 1978); Sherburne v. Sch. Bd., 455 So. 2d 1057 (Fla. Dist. Ct. App. 1984); Sublett v. Sumter County Sch. Bd., 664 So. $2 d 1178$ (Fla. Dist. Ct. App. 1995); Thompson v. Wis. Dep't of Pub. Instruction, 541 N.W.2d 182 (Wis. Ct. App. 1995); Unzueta v. Ocean View Sch. Dist., 8 Cal. Rptr.2d 614 (Cal. Ct. App. 1992); and Von Durjais v. Bd. of Tr., 148 Cal. Rptr. 192 (Cal. Ct. App. 1978).

${ }^{181} 234$ N.E.2d 583 (Ohio 1968).
} 
failed to provide enough evidence to support grounds of immorality and gross inefficiency in the classroom. "Where only a single crime is involved, the crime would either have to be a more serious one or involve a more serious fact situation than that here involved." ${ }^{\text {182 }}$ Hale prevailed on his substantive due process claim, as the school officials based their termination decision on grounds that did not indicate Hale's immorality or gross inefficiency within the classroom.

Beyond questioning whether minor crimes involve sufficient grounds for discipline, courts determined that employers must indicate that an employee's off-duty conduct harmed the students or the school community. In Comings v. State Board of Education, ${ }^{183}$ a junior high school teacher faced revocation of his teaching credential. State board officials found that police arrested and charged Comings with drug possession. Subsequently, a judge found Comings guilty of possession. The state board proceeded with revocation of Comings' certification for immoral and unprofessional conduct, moral turpitude, and unfitness for service.

While Comings did not dispute the criminal charge or conviction, he did dispute that his conduct warranted revocation on the grounds determined by state board officials. Comings asserted that officials did not show that his off-duty conduct consisted of moral turpitude or made him unfit for service. The court agreed, stating: "Whether Comings' conduct adversely affected students or fellow teachers, or in what degree, is not even suggested by the record. The record contains even less evidence of his unfitness to teach." 184 The court, though, went on to indicate that the judgment did not preclude the state board from revoking Comings' credential, if a reopening of the incident brought

\footnotetext{
${ }^{182}$ Id. at 587.

${ }^{183} 100$ Cal. Rptr. 73 (Cal. Ct. App. 1972).

${ }^{184} I d$. at 81 .
} 
forth evidence of moral turpitude or misconduct. ${ }^{185}$ The constitutional right to substantive due process meant that state officials could not make a revocation decision on nonexistent evidence. ${ }^{186}$

Any standard upheld by employers that examines an employee's personal life must meet clearly reasonable and fair criteria. A Nebraska teacher claimed a deprivation of her substantive due process rights in the 1973 case, Fisher $v$. Snyder. ${ }^{187}$ Fisher, a divorced school teacher, lived alone in the small town of Tryon. Her son and his friends often came to town and stayed with Fisher in her one bedroom apartment. Fisher opened up her apartment, as the school secretary had informed her Tryon lacked hotel accommodations. One of her son's friends came to Tryon for a week by himself, while he visited the local school as a requirement for his college degree. Following his week long stay with Fisher, school officials informed her she would not receive a contract for the following school year. School officials further indicated Fisher's conduct, allowing single men to stay with her alone in the apartment, constituted conduct unbecoming a teacher.

Fisher brought suit against the school district arguing violation of her substantive due process rights. She alleged that school officials inferred sexual misconduct from the fact that she let a single man stay overnight in her apartment. Basing her nonrenewal on an inference of misconduct and with no solid evidence made the adverse employment decision arbitrary and capricious. The court agreed with Fisher. "The presence of guests in her home provides no inkling beyond subtle implication and innuendo which would

\footnotetext{
${ }^{185} I d$.

${ }^{186}$ This court considered another case simultaneously with Comings. See Jefferson Union High Sch. v. Jones, 100 Cal. Rptr. 73 (Cal. Ct. App. 1972). While Jones involved a similar fact scenario as Comings, the court found for the school district. Jones failed in his claim, since district officials did provide substantial evidence showing his conduct, criminal drug possession, created an adverse effect on the school community and his ability to perform his professional responsibilities.

${ }^{187} 476$ F.2d 375 (8th Cir. 1973).
} 
impugn Mrs. Fisher's morality. Idle speculation certainly does not provide a basis in fact for the board's inference that there was strong potential of sexual misconduct." ${ }^{188}$ The court declared the nonrenewal arbitrary and capricious. Therefore, school officials violated Fisher's substantive due process rights.

Courts continued to favor employees involved in truly personal off-duty conduct as legal challenges came in the 1980 's. Eleven years after Fisher, a Florida teacher received discipline for her off-duty conduct with a man. In 1984, school board members terminated a teacher in Florida due to concerns over her personal life. ${ }^{189}$ Sherburne lived with a man out of wedlock and permitted the man occasionally to visit her classroom. Students and faculty knew the man lived with Sherburne. Her principal warned her not to advertise the fact that she cohabitated with a man outside of marriage and recommended Sherburne not allow the man to visit her at school. Even so, Sherburne's principal recommended her to the board to receive a new contract for the upcoming school year. The school board, though, refused to grant the contract, citing Sherburne's conduct demonstrated an absence of good moral character and failure to conform to the moral standards expected of county teachers. The board insinuated that too many people in the school and local community knew of Sherburne's lifestyle.

Sherburne sued the school board members, claiming they made their decision without credible evidence. The court agreed with Sherburne that the record lacked any showing of evidence to validate the nonrenewal decision. "We can find no substantial evidence satisfying the requirements that appellant's relationship with Palmer met the test

\footnotetext{
${ }^{188} I d$. at 377.

${ }^{189}$ Sherburne v. School Board, 455 So. 2d 1057 (Fla. Dist. Ct. App. 1984).
} 
of "good cause" justifying her continuing contract rights." ${ }^{190}$ Furthermore, the court found no evidence existed that Sherburne's conduct spawned negative publicity in the community or that the conduct negatively impacted her effectiveness as a teacher. The court found that the employment decision violated Sherburne's right to substantive due process. The decision rested on a subjective community standard, and officials had no hard evidence of immorality. "Private, off-campus conduct ostensibly involving a consensual sexual relationship between a teacher and an adult of the opposite sex cannot, in and of itself, provide good cause for a school board's rejection of a teacher nominated for employment."191

In the 1990's courts held employers to a high standard when discipline occurred for off-duty conduct. Regardless of the nature of the conduct or resulting publicity emerging from the conduct, an employee deserves minimal protection under the right of substantive due process. In a 1999 case, In re Termination of Kibbe, ${ }^{192}$ a tenured teacher and coach lost his job due to alcohol-related conduct. Kibbe taught history, physical education, and driver education classes for the district. School officials suspended Kibbe, after his arrest for DUI and resisting arrest. They argued that Kibbe's arrest compromised his capacity effectively to teach driver education courses and his role model ability with his students. Furthermore, Kibbe's conduct caused a great deal of publicity within the community. Kibbe, though, claimed he stopped drinking and had become an active member of Alcoholics Anonymous. A hearing officer upheld the suspension decision.

Kibbe brought suit against the school district claiming the district lacked a showing of good cause for the suspension decision. The court agreed with Kibbe indicating the

\footnotetext{
${ }^{190}$ Id. at 1061 .

${ }^{191}$ Id. at 1062.

192996 P.2d 419 (N.M. 1999).
} 
suspension violated his right to substantive due process. The court considered the definition for just cause: "A reason that is rationally related to an employee's competence or turpitude or the proper performance of the employee's duties." 193 The court found Kibbe's conduct in no way related to his competence as a teacher, particularly in teaching history and physical education. "The school board did not present evidence that Kibbe's arrest actually affected his ability to teach effectively or to serve as a proper role model for students." ${ }^{194}$ In fact, the court believed Kibbe potentially could use the story of his arrest to talk with his students about the risks of drinking and driving. ${ }^{195}$

Additionally, the court considered the fact that school officials dealt differently with another teacher who received a DUI. In that instance, officials failed to take disciplinary action against the teacher. The court failed to see how Kibbe's conduct differed from the conduct in the prior situation. "While a school board's decision not to impose disciplinary action against an employee for certain conduct does not foreclose disciplinary action against a different employee in the future for similar conduct, the record is devoid of any meaningful distinction between Kibbe's conduct and that of the other Elida school teacher." ${ }^{196}$ School officials violated Kibbe's right to substantive due process as their discipline process lacked basic fairness.

Courts provide wide latitude for employers to choose to discipline their employees for conduct occurring away from the schoolhouse. Nevertheless, courts maintain a strong interest in assuring that discipline meets fair and just standards.

\footnotetext{
${ }^{193} \mathrm{Id}$. at 422.

${ }^{194} \mathrm{Id}$. at 423.

${ }^{195}$ Id.

${ }^{196} I d$.
} 


\section{Equal Protection}

Equal protection under the law is "[t]he constitutional guarantee under the

Fourteenth Amendment that the government must treat a person or class of persons the same as it treats other persons or classes in like circumstances." ${ }^{, 197}$ When considering a claim of equal protection, the court must first determine if government officials intended to discriminate by its action. Without intent to discriminate on the part of government, no equal protection violation occurs. If the government intended to discriminate, the court must then determine if the government action burdens a suspect class or a fundamental right. The courts use three analyses to assess equal protection claims: the "strict scrutiny" test, the "intermediate scrutiny" test, or the "rational basis" test. ${ }^{198}$

The researcher identified sixteen cases where courts determined the outcome based on a right to equal protection. Of the sixteen cases, employers prevailed nine times and employees prevailed seven times (see Table 9).

Table 9: Types of off-duty conduct in right to equal protection cases by prevailing party.

\begin{tabular}{|c|c|c|c|}
\hline Type of Off-Duty Conduct & $\begin{array}{l}\text { Number of } \\
\text { Cases }\end{array}$ & $\begin{array}{l}\text { Employer } \\
\text { Prevails }\end{array}$ & $\begin{array}{c}\text { Employee } \\
\text { Prevails }\end{array}$ \\
\hline Affiliation & 1 & & 1 \\
\hline Alcohol & 1 & 1 & \\
\hline Drugs & 1 & 1 & \\
\hline Fraudulent Behavior & 1 & 1 & \\
\hline Homosexuality & 3 & 1 & 2 \\
\hline Inappropriate Relationship w/Minor & 1 & 1 & \\
\hline Pregnancy Out-of-Wedlock & 3 & & 3 \\
\hline Sexual Exhibitionism/Public Display & 1 & 1 & \\
\hline Other Criminal Conduct & 2 & 2 & \\
\hline Other Non-Criminal Conduct & 2 & 1 & 1 \\
\hline Totals & 16 & 9 & 7 \\
\hline
\end{tabular}

\footnotetext{
${ }^{197}$ BLACK's LAW DiCTIONARY, supra note 44, at 441.

${ }^{198}$ See Chapter 2, p. 56 for a further discussion on equal protection under the law, suspect classes, and fundamental rights.
} 
In addition to claiming a right to equal protection, employees claimed a right to association, freedom of speech, right to reputation, right to due process, and right to substantive due process. Employers defended their actions by claiming the following: no deprivation of equal protection, no deprivation of due process, and no deprivation of substantive due process. The equal protection cases, ranging from $1961-2002$, included fourteen teachers, one guidance counselor, and one group of employees.

Employer Prevails. ${ }^{199}$

When courts favor employers on the issue of equal protection, the following considerations arise: Does the employer action intend to discriminate, are similarly situated employees treated differently, and, if so, does the employer possess the required interest for the adverse employment decision?

In two cases, courts found employers possessed no intent to discriminate. When government action does not involve intent to discriminate, no violation of a right to equal protection occurs. In 1997, a tenured elementary school teacher claimed infringement of his right to equal protection. ${ }^{200}$ Gedney's arrest and subsequent charge for possession of cocaine led the school board to consider termination proceedings. The criminal system never convicted Gedney but granted him accelerated rehabilitation. Even so, the school board terminated Gedney.

Gedney claimed his drug addiction fell under the definition of a disability, and therefore, the board could not use the addition as basis for termination. While substance

\footnotetext{
${ }^{199}$ See Gedney v. Bd. of Educ., 703 A.2d 804 (Conn. App. Ct. 1997); In re Grossman, 316 A.2d 39 (N.J. Super. Ct. App. Div. 1974); Logan v. Warren County Bd. of Educ., 549 F.Supp. 145 (S.D. Ga. 1982); Pordum v. Bd. of Regents, 357 F.Supp. 222 (N.D.N.Y. 1973); Purifoy v. State Bd. of Educ., 106 Cal. Rptr. 201 (Cal. Ct. App. 1973); Rowland v. Mad River Local Sch. Dist., 730 F.2d 444 (6th Cir. 1984); Shelton v. Richmond Pub. Sch., 186 F.Supp.2d (E.D. Va. 2002); Vogulkin v. State Bd. of Educ., 15 Cal Rptr. 335 (Cal. Dist. Ct. App. 1961); and Vukadinovich v. Bd. of Sch. Tr., 978 F.2d 403 (7th Cir. 1992).

${ }^{200}$ Gedney v. Bd. of Educ., 703 A.2d 804 (Conn. App. Ct. 1997).
} 
abuse qualified as a statutorily defined disability, the court found the board possessed another reason for the dismissal. "The plaintiff's misconduct was felonious activity leading to an arrest that, despite his having a disability, would have disqualified him from employment or justified his termination." ${ }^{201}$ Becuase the board members based their decision on Gedney's criminal conduct and not on his disability, Gedney's equal protection claim failed.

Twenty-four years prior to Gedney, a tenured teacher faced revocation of his teaching credentials after serving a three-year prison sentence for conspiracy involving bribery. ${ }^{202}$ Pordum's employer granted him a leave of absence and twice extended the leave to accommodate Pordum's prison sentence. When Pordum received parole, local school officials sought to reinstate him. The state commissioner, though, enjoined the school from reinstating Pordum and began revocation proceedings.

In court, Pordum claimed the state commissioner violated his right to equal protection. The court, however, dismissed this claim, as no proof of discrimination existed. "There is a legitimate state end . . . and no invidious discrimination shown."203 Without employer intent to discriminate, a claim of equal protection violation fails.

Beyond a proof of discrimination, employees must also demonstrate inequity of treatment. When employer action equally impacts similarly situated employees, a claim to equal protection fails. The researcher identified two such cases.

In 1984, the Sixth Circuit Court of Appeals considered an equal protection argument in Rowland v. Mad River Local School District. ${ }^{204}$ Rowland, an untenured guidance

\footnotetext{
${ }^{201}$ Id. at 806-807.

202357 F.Supp. 222 (N.D.N.Y. 1973).

${ }^{203} \mathrm{Id}$. at 226 .

${ }^{204} 730$ F.2d 444 (6th Cir. 1984). See Chapter 4, p. 103 for a further discussion on Rowland.
} 
counselor, told another employee that she was bisexual and currently involved in a relationship with another woman. The school principal, after hearing about the conversation, suspended Rowland with pay and school officials later reassigned her to an administrative position with no student contact. The school district failed to renew her contract for the next year.

Rowland claimed deprivation of her constitutionally protected right to equal protection under the law. The circuit court restricted the analysis of Rowland's claim to whether the school district treated similarly situated employees differently than they treated Rowland. The court found no evidence existed that similarly situated employees received different treatment in regard to discussing their sexual preferences. "There was no showing that heterosexual school employees in situations similar to hers would have been, or would be treated, differently for making their personal sexual preferences the topic of comment and discussion in the high school community." ${ }^{205}$ Rowland's equal protection claim failed to persuade the court and the school district prevailed.

Almost twenty years after Rowland, a similar judicial outcome came in Shelton $v$. Richmond Public Schools, ${ }^{206}$ when an African American substitute teacher failed to provide information related to prior felony convictions on his application. The two cases, when examined for the precedent they set, indicate the unwillingness of courts to grant employees' reversal wishes, when the conduct involves cause for discipline within the school system.

\footnotetext{
${ }^{205}$ Id. at 452.

206 186 F.Supp.2d (E.D. Va. 2002).
} 
School officials terminated Shelton's substitute teaching contract when they learned of his criminal past. Shelton claimed the school board action resulted from two incidents between Shelton and students involving some racial overtones. He asserted the termination was only a pretext for racial discrimination. No file existed documenting these two incidents.

Shelton claimed the termination violated his constitutionally protected right to equal protection, but the district court rejected his claim. Officials presented evidence that they terminated twelve other employees for the same reason -- possessing previous felony records. For Shelton to prevail, the district's treatment of him would have had to differ from how they treated similarly situated employees. Because district officials had applied the same policy to twelve other employees, no difference in treatment existed. Finding Shelton's further contention unpersuasive, that his termination was a pretext for racial discrimination, the court sided with the employer. No evidence existed to indicate school officials even documented or otherwise considered Shelton's two incidents with students that involved racial overtones. ${ }^{207}$ His equal protection claim failed, as no intent to discriminate on the part of his employer existed.

When an employer intends to discriminate and that discrimination burdens a suspect class or a fundamental right, the employer must possess a compelling interest for the discrimination and no lesser way to achieve the same interest. When discriminatory action does not burden a suspect class or a fundamental right, the employer must simply present a rational basis for the discriminatory action. In these instances, the legality of government action is presumed, and the action must relate to some government interest.

${ }^{207}$ Id. at 653 . 
In 1973, Purifoy v. State Board of Education ${ }^{208}$ involved a claim of violation of the right to equal protection. Law enforcement officers arrested and charged Purifoy, a tenured middle school teacher, with committing a public sex offense. School officials relieved Purifoy of his teaching position immediately after his arrest. Following Purifoy's criminal conviction by a jury, the state board suspended and later terminated his life teaching credential. California's education code required the revocation of teaching for any person convicted of a public sex offense.

Purifoy brought suit against the state board claiming the revocation violated his right to equal protection. He asserted the state possessed no compelling interest in discriminating against him. The court denied his claim, citing Vogulkin v. State Board of Education. ${ }^{209}$ "Certain areas of human activity, if participated in, may be such that no further right should exist in the person to be a member of a teaching profession. ${ }^{, 210} \mathrm{In}$ addition to finding the state possessed a compelling interest in keeping persons convicted of public sex offenses out of the classroom, the court found the state's policy gave equal treatment to any employee in a similar position as Purifoy. The state predetermined this type of criminal activity constituted a dangerous element in a school community. No violation to Purifoy's right to equal protection occurred with the state board's adverse employment decision.

The following year saw an East Coast court find for the employer on similar grounds. A New Jersey appeals court considered an equal protection claim, in In re Grossman, ${ }^{211}$ involving a tenured male teacher who underwent a sex change operation to change his

\footnotetext{
${ }^{208} 106$ Cal. Rptr. 201 (Cal. Ct. App. 1973).

20915 Cal Rptr. 335 (Cal. Dist. Ct. App. 1961).

${ }^{210}$ Id. at 339.

${ }^{211} 316$ A.2d 39 (N.J. App. Div. 1974).
} 
male anatomy to that of a female. Grossman acquired the necessary approval for medical leave, but did not inform school officials of the type of surgery. When Grossman returned from surgery, he requested a new teaching certificate under a female name, Paula Grossman. District officials refused his request and urged him to resign. School officials contended Grossman's continued employment would cause potential harm to his students, aged ten to twelve. A psychological review further indicated Grossman's presence in the classroom might emotionally harm students. Moreover, school officials expressed concern over the sensationalism Grossman's presence would cause in the classroom and in the community. Citing these concerns, the district terminated Grossman.

Grossman brought suit against the school district arguing a violation of his right to equal protection. The standard of review for this court involved assessing whether the district's actions rationally related to the aims of the school district. The court found the district possessed a rational basis for their termination decision. "An individual can be removed from the teaching profession only upon a showing that his retention in the profession poses a significant danger of harm to either students, school employees, or others who might be affected by his actions as a teacher."212 The court acknowledged the preponderance of evidence indicating Grossman's retention as a teacher possessed the potential for great harm. "Where a teacher's presence in the classroom would create a potential for psychological harm to the students, the teacher is unable properly to fulfill his or her role and his or her incapacity has been established." ${ }^{213}$ The district had a valid reason for terminating Grossman, and hence, Grossman's equal protection claim failed.

\footnotetext{
${ }^{212}$ Id. at $48-49$.

${ }^{213}$ Id. at 49.
} 
Employee Prevails. ${ }^{214}$

When a government action discriminates against an employee and the required governmental interest for the discrimination does not exist, courts maintain that the discrimination violates an employee's right to equal protection. Despite an employer's need to foster a safe and disruption-free school environment, arbitrary or uneven treatment on the part of employers to maintain order often conflicts with the employees' right. Employers must use unwavering criteria in meting out discipline for off-duty conduct. The following cases present some specific scenarios where adverse employment actions violated employees' right to equal protection.

In Andrews v. Drew Municipal Separate School District, ${ }^{215}$ two African American female employees challenged a district policy barring persons with illegitimate children the opportunity for employment. The district superintendent, based on his moral convictions and concern for the morality of school employees, created and implemented the policy without the knowledge of the school board. The superintendent believed that allowing employees with illegitimate children to work in a school environment contributed to the problem of teenage pregnancies.

The superintendent claimed the policy applied to all employees, regardless of race or gender. Both Andrews and Rogers alleged the policy created an unconstitutional classification based on gender and race. The district never used the policy to deny employment to a Caucasian applicant or a male applicant.

\footnotetext{
${ }^{214}$ See Allen v. Bd. of Educ., 584 S.W.2d 408 (Ky. Ct. App. 1979); Andrews v. Drew Mun. Separate Sch. Dist., 371 F.Supp. 27 (N.D. Miss. 1973); Avery v. Homewood City Bd. of Educ., 674 F.2d 337 (5th Cir. 1982); Cameron v. Bd. of Educ., 795 F.Supp. 228 (S.D. Ohio 1991); Glover v. Williamsburg Local Sch. Dist., 20 F.Supp.2d 1160 (S.D. Ohio 1998); Gosney v. Sonora Indep. Sch. Dist., 603 F.2d 522 (5th Cir. 1979); and Weaver v. Nebo Sch. Dist., 29 F.Supp.2d 1279 (D. Utah 1998).

215371 F.Supp. 27 (N.D. Miss. 1973).
} 
The United States district court favored the teachers, finding the policy deprived them of equal protection. The court found the district provided no justification for the policy related to the operation of the school. While the court acknowledged that school officials possess authority to implement reasonable standards and hiring criteria for all employees, the court stated, "Barring an otherwise qualified person from being employed, or considered for employment, in the public schools merely because of one's previously having had an illegitimate child has no rational relationship to the objectives ostensibly sought to be achieved by the school officials."216 The employees prevailed on their equal protection claim, as the policy created an "essentially discriminatory effect" upon unmarried women. ${ }^{217}$

Twenty-five years later, Weaver $v$. Nebo School District ${ }^{218}$ involved the discipline of a homosexual high school teacher and women's volleyball coach. Weaver's homosexual lifestyle created a stir in the school community and beyond. Ultimately, school officials restricted Weaver from discussing her sexual orientation. Officials also refused to renew Weaver's contract for the volleyball coaching position.

The district court considered Weaver's claim of deprivation of her right to equal protection. The court used the rational basis test to consider Weaver's claim. While the United States Supreme Court fails to recognize a person's sexual orientation as a status enjoying heightened scrutiny, this court acknowledged an "irrational prejudice" prompted the school district's action not to allow Weaver to discuss her sexuality or to continue coaching the volleyball team. "The negative reaction some members of the community

\footnotetext{
${ }^{216} I d$. at 31 .

${ }^{217} I d$ at 36.

${ }^{218} 29$ F.Supp.2d 1279 (D. Utah 1998). See Chapter 4, p. 107 for a further discussion on Weaver.
} 
may have to homosexuals is not a proper basis for discriminating against them." ${ }^{219}$ The school district failed to provide any rational basis for their discrimination or how Weaver's sexual orientation related to her position as volleyball coach and the duties inherent within that position. In declining to renew her coaching contract, the school district violated Weaver's right to equal protection.

Courts also require fairness for school district personnel across all positions. When similarly situated employees receive different treatment by employers, courts find an equal protection violation occurs. Two cases in 1979, favored employees on their claim of equal protection, because similarly situated employees received dissimilar treatment.

In Allen v. Board of Education, ${ }^{220}$ two Kentucky school teachers filed applications to run for state government offices. Prior to the election the superintendent informed both teachers that school policy required any employee running for elected office to take leave without pay the month prior to the election. The teachers filed for an injunction and the court prohibited enforcement of the policy prior to the election. After the election, though, the trial court favored the school district.

On appeal, the court asserted school boards possess the authority to set reasonable standards for employee activity, but found the disputed requirement inappropriate. Furthermore, the court declared the requirement a violation of the employees' right to equal protection. "Teachers engaged in other time consuming activities were not required to take a leave of absence. There was no showing that political campaigning was the only activity that would adversely affect the quality of education and warrant a mandatory

\footnotetext{
${ }^{219}$ Id. at 1289.

${ }^{220} 584$ S.W.2d 408 (Ky. Ct. App. 1979).
} 
leave of absence."221 The school district discriminated against these two employees by requiring them to take leave, while not making other employees take leave to pursue offduty activities. The employees prevailed on their claim that the application of the requirement deprived them of equal protection.

Courts consider off-duty conduct, regardless of its intents and purposes, in conjunction with other non-teaching activities. A case in 1979, Gosney v. Sonora Independent School District, ${ }^{222}$ clearly illustrates the point. Mr. Gosney worked as a principal and Mrs. Gosney taught for the Sonora school district. In addition, the Gosneys owned and managed a cattle ranch. In an attempt to expand their business ventures, the Gosneys acquired a retail store and began selling dry goods. District officials expressed concern related to the Gosneys' increased involvement in outside business interests, reminding them of the district's "no outside employment" policy. Mr. Gosney hired a manager for the retail operation but school officials remained apprehensive. When the couple refused to relinquish the retail business, school board members decided not to renew either of their contracts.

The Gosneys alleged the school district violated their right to equal protection and this court agreed. The court found that the school district arbitrarily and discriminatorily applied a "no outside employment" standard to the Gosneys. The court considered evidence that other district employees maintained outside jobs, such as cattle ranching, yet, officials never applied the restriction in those instances. "A public education system may not single out an instructor or administrator for the imposition of restrictions which

\footnotetext{
${ }^{221}$ Id. at 410 .

${ }^{222} 603$ F.2d 522 (5th Cir. 1979).
} 
are not applicable to others similarly situated." ${ }^{223}$ While contending the district could maintain a policy restricting outside employment, the court insisted that the policy must apply equally to all employees. Otherwise, the policy tolerates discriminatory application and violates the equal protection clause of the fourteenth amendment.

The same standards that applied above extend to personal relationships as well. Public displays of affection allowed for one couple cannot become grounds for discipline for another couple, for example a homosexual couple. In Glover v. Williamsburg Local School District, ${ }^{224}$ officials became concerned about a teacher's homosexual lifestyle. During Glover's first year of teaching, he received a low evaluation score. His supervisor informed him the low score reflected an inability to conform to professional standards. The supervisor based his comments on a rumor that Glover's life partner attended a class party and parents and students observed Glover holding hands with his partner. No member of the school administration checked the validity of the rumor, and Glover never received any warning related to his behavior.

During the second half of the school year, school administrators increased observations in Glover's classroom. At several points, administrators documented that Glover possessed poor behavior management skills. They used this reason as basis for Glover's nonrenewal. Glover appealed the nonrenewal to no avail.

Glover brought suit against the school district claiming the nonrenewal violated his right to equal protection. Glover claimed that another teacher who lost her contract later received a contract from the district. Glover alleged he possessed equal experience with

\footnotetext{
${ }^{223} I d$. at 527.

${ }^{224} 20$ F.Supp.2d 1160 (S.D. Ohio 1998).
} 
this teacher and he received better overall evaluations. Glover claimed the district discriminated against him because of his sexual orientation.

The court asserted homosexuals deserve the same protection as any other identifiable group that faces disparate treatment via government action. Any government action discriminating against homosexuals solely because of abhorrence to that lifestyle cannot withstand judicial review. ${ }^{225}$ The court found that district officials' justification for nonrenewal, that Glover possessed poor behavior management skills, a pretext for the real reason. "The board's purported reason for Glover's nonrenewal was pretextual, and in fact the Board discriminated against Glover on the basis of his sexual orientation."226 Glover prevailed on his equal protection claim, and the court awarded him reinstatement with the district, compensatory damages, and attorney fees.

As with the previous cases, the most important standard employers must apply is equality across all levels and classes of employment. In 1982, a federal appeals court heard a case involving an employee's out-of-wedlock pregnancy. ${ }^{227}$ The Homewood school board implemented a policy that all teachers must notify school officials by the fourth month of pregnancy. When Avery became pregnant out-of-wedlock, she failed to notify school officials until the eighth month. When the superintendent met with Avery, the superintendent told her she failed to abide by the notice rule. The superintendent also urged Avery to resign because of the moral issues related to out-of-wedlock pregnancies. When Avery refused to resign, school board members terminated her on grounds of immorality, neglect of duty, and insubordination.

\footnotetext{
${ }^{225}$ Id. at 1169.

${ }^{226} \mathrm{Id}$. at 1174 .

${ }^{227}$ Avery v. Homewood City Bd. of Educ., 674 F.2d 337 (5th Cir. 1982).
} 
On appeal, the Fifth Circuit Court of Appeals held for Avery and rejected the decision rendered by the lower court. This court assumed that Avery's out-of-wedlock pregnancy enjoyed constitutional protection. The school board, therefore, needed to prove to the court they reached the termination decision aside from Avery's pregnancy. "'No evidence in the record supports the proposition that Avery would have been dismissed, absent consideration of her out-of-wedlock pregnancy.,228

The court further determined that prohibiting employment based on Avery's unwed status violated her fundamental right. While school officials argued that Avery's pregnancy made her unfit to teach, the court insisted unwed parenthood does not rise to a per se proof of immorality nor does terminating an unwed parent rationally relate to the work of the school. Avery prevailed on her claim to a constitutional right to equal protection.

Courts strongly acknowledge employees' right to equal protection under the law in cases related to off-duty conduct. The courts require that employers treat employees in similar circumstances equally.

\section{Other Data}

In addition to a critical examination of the legal theories used by courts in the cases related to the research question, the researcher collected a variety of complementary data. This data afforded an appreciation of the overall context for the body of case law, as well as the opportunity to gain detailed information regarding the specific components of each case.

${ }^{228}$ Id. at 341 . 
Employers often used two frameworks to justify their adverse employment decisions. One framework views teachers as role models. The other framework relies on the nexus theory. The courts do not define either of these theories as a legal right, though courts often apply the theories during their decision making process. Of the 161 cases identified, courts turned to the role model theory in 66 cases and to the nexus theory in 79 cases $^{229}$ (see Table 10).

Table 10: Judicial references to role model and nexus theories by decade.

\begin{tabular}{|c|c|c|c|}
\hline Decade & Total \# of Cases & Role Model & Nexus \\
\hline Pre-1930's & 1 & 1 & \\
\hline 1930's & 2 & 2 & \\
\hline 1940's & 1 & 1 & \\
\hline 1950's & 8 & 4 & \\
\hline 1960's & 13 & $(46 \%)$ & $(23 \%)$ \\
\hline 1970's & 47 & $(45 \%)$ & $(64 \%)$ \\
\hline 1980's & 39 & $(38 \%)$ & $(64 \%)$ \\
\hline 1990's & 35 & $(29 \%)$ & $(43 \%)$ \\
\hline 2000 's & 15 & $(40 \%)$ & $(40 \%)$ \\
\hline Totals & 161 & $66 \quad(41 \%)$ & $(49 \%)$ \\
\hline
\end{tabular}

\section{Judicial Use of the Role Model Theory}

For centuries, educational theorists acknowledged that teachers do more than impart intellectual wisdom. Many in society ascribe to the "teacher-as-role model" theory and expect that a teacher's conduct and character remain above reproach. The actions of teachers, even more so than their words, become paramount in what they model for children. "The public has typically held the view that the teacher should be an exemplar;

\footnotetext{
${ }^{229}$ Thirty-three cases included a judicial reference to both the role model theory and the nexus theory.
} 
that is, he should be a model for his students. ${ }^{, 230}$ Furthermore, society maintains an interest in a teacher's conduct on and off the clock. ${ }^{231}$

While courts address and often promote this theory, courts do not make legal outcomes based simply or directly on this theory. Unlike the legal rights discussed in the previous section, courts never resolve a case on the role model theory. On the other hand, the "teacher-as-role model" theory, while prevalent for centuries, served as one of the lenses through which judges "see" these cases and through which the researcher studied the cases. It is critical to appreciating fully the results of these cases to understand the role model theory. Many employees and employers asserted the role model theory when arguing their cases in court. Furthermore, courts considered the theory in 66 of the 161 cases. $^{232}$

Employees engaged in thirteen types of off-duty conduct (see Table 11).

Table 11: Types of off-duty conduct in role model cases by prevailing party.

\begin{tabular}{|c|c|c|c|}
\hline Type of Conduct & $\begin{array}{c}\text { Number of } \\
\text { Cases }\end{array}$ & $\begin{array}{l}\text { Employer } \\
\text { Prevails }\end{array}$ & $\begin{array}{c}\text { Employee } \\
\text { Prevails }\end{array}$ \\
\hline Affiliation & 4 & 3 & 1 \\
\hline Alcohol & 4 & 3 & 1 \\
\hline Drugs & 9 & 6 & 3 \\
\hline Fraudulent Behavior & 3 & 3 & \\
\hline Homosexuality & 4 & 2 & 2 \\
\hline Inappropriate Relationship w/Adult & 5 & 3 & 2 \\
\hline Inappropriate Relationship w/Minor & 3 & 3 & \\
\hline Marital Misbehavior & 3 & 2 & 1 \\
\hline Out-of-Wedlock Pregnancy & 6 & & 6 \\
\hline Sexual Exhibitionism/Public Display & 5 & 4 & 1 \\
\hline Theft/Robbery & 6 & 4 & 2 \\
\hline Other Criminal Conduct & 12 & 10 & 2 \\
\hline Other Non-Criminal Conduct & 2 & 1 & 1 \\
\hline Totals & 66 & 44 & 22 \\
\hline
\end{tabular}

${ }^{230}$ Bullock \& Faber, The Right of Privacy of Public School Employees, Feb. 9, 1989, available in ERIC, File No. ED303861.

${ }^{231}$ Byrdena M. MacNeil, Disciplining the Off-Duty Teacher, EDuc. CAN. 2000, at 36, 36-37.

${ }^{232}$ See Chapter 2, p. 9-32 for a further discussion regarding the role model theory. 
Employees in these cases claimed a variety of legal rights, with the exception of freedom of religion and the right to reputation. Their arguments included no right to privacy, due process given, and no right to equal protection. The cases, ranging from 1898 to 2004, included the following types of employees: teachers, administrators, guidance counselors, coaches, and one group of employees.

Employer Prevails. ${ }^{233}$

The following cases describe instances where courts asserted the role model theory in their decisions. The specific off-duty conduct involved in these cases varies from marital misbehavior to criminal behavior. All the cases share one similarity. These courts affirmed that teachers must act as role models, and furthermore, their specific off-duty conduct contravened that expectation.

\footnotetext{
${ }^{233}$ See Adams v. State of Fla., Prof'l Practices Council, 406 So. 2d 1170 (Fla. Dist. Ct. App. 1981); Appeal of Batrus, 26 A.2d 121 (Pa. Super. Ct. 1942); Baird v. Sch. Dist., 287 P. 308 (Wyo. 1930); Baker v. Sch. Dist., 371 A.2d 1028 (Pa. Commw. Ct. 1977); Bd. of Dirs. v. Davies, 489 N.W.2d 19 (lowa 1992); Bd. of Educ. v. Calderon, 110 Cal. Rptr. 916 (Cal. Ct. App. 1974); Bd. of Educ. v. Wilkinson, 270 P.2d 82 (Cal. Dist. Ct. App. 1954); Denton v. South Kitsap Sch. Dist., 516 P.2d 1080 (Wash. Ct. App. 1973); Dominy v. Mays, 257 S.E.2d 317 (Ga. Ct. App. 1979); Dupree v. Sch. Comm. of Boston, 446 N.E.2d 1099 (Mass. App. Ct. 1983); Ellis v. Ambach, 508 N.Y.S.2d 624 (N.Y. App. Div. 1986); Faxon v. Sch. Comm., 120 N.E.2d 772 (Mass. 1954); Feagin v. Everett, 652 S.W.2d 839 (Ark Ct. App. 1983); Freeman v. Town of Bourne, 49 N.E. 435 (Mass. 1898); Gaylord v. Tacoma Sch. Dist., 559 P.2d 1340 (Wash. 1977); Gedney v. Bd. of Educ., 703 A.2d 804 (Conn. App. Ct. 1997); Hainline v. Bond, 824 P.2d 959 (Kan. 1992); Horosko v. Sch. Dist., 6 A.2d 866 (Pa. 1939); In re Bay, 378 P.2d 558 (Or. 1963); In re Thomas, 926 S.W.2d 163 (Mo. Ct. App. 1996); Jefferson Union High Sch. v. Jones, 100 Cal. Rptr. 73 (Cal. Ct. App. 1972); Jenkyns v. Bd. of Educ., 294 F.2d 269 (D.C. Cir. 1961); Kenai Peninsula Borough Bd. of Educ. v. Brown, 691 P.2d 1034 (Alaska 1984); Kinniry v. Abington Sch. Dist., 673 A.2d 429 (Pa. Commw. Ct. 1996); Lesley v. Oxford Area Sch. Dist., 420 A.2d 764 (Pa. Commw. Ct. 1980); McCullough v. Ill. State Bd. of Educ., 562 N.E.2d 1233 (IIl. App. Ct. 1990); Melzer v. Bd. of Educ., 336 F.3d 185 (2nd Cir. 2003); Moser v. State Bd. of Educ., 101 Cal. Rptr. 86 (Cal. Ct. App. 1972); Perryman v. Sch. Comm., 458 N.E.2d 748 (Mass. App. Ct. 1983); Pettit v. State Bd. of Educ., 513 P.2d 889 (Cal. 1973); Purifoy v. State Bd. of Educ., 106 Cal. Rptr. 201 (Cal. Ct. App. 1973); Purvis v. Marion County Sch. Bd., 766 So. $2 d 492$ Fla. Dist. Ct. App. 2000); Ross v. Springfield Sch. Dist., 691 P.2d 509 (Or. Ct. App. 1984); Sarac v. State Bd. of Educ., 57 Cal. Rptr. 69 (Cal. Ct. App. 1967); Satterfield v. Bd. of Educ., 556 N.W.2d 888 (Mich. Ct. App. 1996); Scott v. Bd. of Educ., 156 N.E.2d 1 (Ill. App. Ct. 1959); Startzel v. Commw., 562 A.2d 1005 (Pa. Commw. Ct. 1989); Sullivan v. Meade Indep. Sch. Dist., 530 F.2d 799 (8th Cir. 1975); Tomerlin v. Dade County Sch. Bd., 318 So. 2d 159 (Fla. Dist. Ct. App. 1975); Vogulkin v. State Bd. of Educ., 15 Cal Rptr. 335 (Cal. Dist. Ct. App. 1961); Watson v. State Bd. of Educ., 90 Cal. Rptr. 468 (Cal. Ct. App. 1971); Williams v. Sch. Dist., 417 P.2d 376 (Ariz. Ct. App. 1966); Yanzick v. Sch. Dist., 641 P.2d 431 (Mont. 1982); and Zelno v. Lincoln Intermediate Unit 12 Bd. of Dirs., 786 A.2d 1022 (Pa. Commw. Ct. 2001).
} 
In the earliest identified case related to the research question, Freeman $v$. Town of Bourne, ${ }^{234}$ the court addressed the issue of a school employee's character. A grand jury indicted Donnocker, a superintendent of schools, on charges of adultery. School board members dismissed him and he sued to recover for services rendered. This court denied Donnocker's right to recover because the town dismissed him for cause. About the "cause," the court stated, "It needs no extended argument to show that not merely good character, but good reputation, is essential to the greatest usefulness in such a position as that of superintendent of schools."235 The court found Donnocker's dismissal justified, as his adulterous activity made him unfit for continued service.

The role model theory appears again in the court's decision in Appeal of Batrus, ${ }^{236}$ a case involving a teacher's off-duty liquor business. Batrus conducted the business under a false name, which led to trouble with the Liquor Control Board. School officials did not know about Batrus' liquor business until the Liquor Control Board began their investigation. School officials charged Batrus with immorality and incompetency. Batrus lost her job, because school officials found her business venture incompatible with her role as a teacher.

Batrus argued that her conduct did not meet the legal standard of immorality but the court disagreed. The court determined that teachers must live up to high standards and Batrus' conduct clearly violated those standards. "Batrus is guilty of such a course of conduct as offends the morals of the community and is a bad example to the youth."237 The court affirmed the notion of teachers as role models.

\footnotetext{
${ }^{234} 49$ N.E. 435 (Mass. 1898).

${ }^{235} \mathrm{Id}$. at 436.

${ }^{236} 26$ A.2d 121 (Pa. Super. Ct. 1942).

${ }^{237}$ Id. at 124.
} 
Some public school employees received public scrutiny for their affiliation with certain organizations. In 2003, one court found a teacher's off-duty affiliations deviated from a societal expectation parents and other community members hold regarding the role of teachers. In Melzer v. Board of Education, ${ }^{238}$ school officials terminated Melzer, a tenured high school teacher, for his membership and leadership in the North American Man/Boy Love Association (NAMBLA). ${ }^{239}$ Concerns emerged due to NAMBLA's stated goal of bringing about legislative change governing sexual activity between men and boys. Many parents became enraged as publicity of Melzer's NAMBLA affiliation increased. School officials terminated Melzer, citing serious disruption and permanent loss of parental confidence in the school.

The court found the termination decision justified. Furthermore, the court articulated strong support for the "teacher as role model" theory. In the decision, the court suggested parents would fear Melzer's continued influence and predilections over their children. "Melzer's position as a teacher leaves him somewhat beholden to the views of parents in the community."240 The court agreed that Melzer served as a role model for his students, and "what" he potentially would role model concerned the community too much to allow him to remain in his teaching position.

The role model theory received particularly strong endorsement in court decisions that addressed alcohol-related off-duty conduct. Courts found that excessive alcohol use, particularly when it involved criminal conduct, failed to satisfy acceptable role model standards.

\footnotetext{
238336 F.3d 185 (2nd Cir. 2003).

${ }^{239}$ See Chapter 4, p. 92 and p. 104 for further discussion regarding Melzer.

${ }^{240}$ Melzer, 336 F.3d 185 at 199.
} 
In 1959, an Illinois teacher, Scott, lost her position, as a result of multiple alcoholrelated arrests. ${ }^{241}$ While Scott possessed an excellent teaching record, school officials decided to terminate her in the best interests of the school. Specifically, school officials cited Scott's arrests for intoxication and the reputation the arrests garnered.

The court upheld the adverse employment decision finding Scott's behavior contravened societal expectations for teacher behavior:

It is the opinion of this court that a teacher is something of a leader to pupils of a tender age, resulting in admiration and emulation, and that the Board might properly fear the effect of social conduct in public, not in keeping with the dignity and leadership they desired from teachers. ${ }^{24}$

The court presumed that Scott's job as a teacher included being a role model for her students.

In Zelno v. Lincoln Intermediate Unit 12 Board of Directors, ${ }^{243}$ a Pennsylvania court also presumed that teachers are role models, though this case occurred more than forty years after Scott. Zelno, a tenured teacher for a drug and alcohol residential program, faced a series of criminal charges related to DUI and driving without a license. ${ }^{244}$ School officials dismissed her on grounds of immorality and this court agreed. Zelno argued that school officials failed to indicate how her immoral behavior corrupted her students. The court, though, stated, "Showing that her conduct impacted on a specific student or her ability to teach is not relevant to show immorality; proof of the conduct makes her a bad role model." ${ }^{245}$ Furthermore, the court found Zelno's off-duty conduct "offended the

\footnotetext{
${ }^{241}$ Scott v. Board of Education, 156 N.E.2d 1 (Ill. App. Ct. 1959).

242 Id. at 3.

243786 A.2d 1022 (Pa. Commw. Ct. 2001).

${ }^{244}$ See Chapter 4, p. 141 for further discussion regarding Zelno v. Lincoln Intermediate Unit 12 Bd. of Dirs.

${ }^{245}$ Zelno, 786 A.2d at 1026.
} 
morals of her community." ${ }^{246}$ In this decision, the court affirmed that teaching positions require an employee to model a certain moral standard, a standard which Zelno's conduct obviously failed to achieve.

Courts also integrated the role model theory into decisions involving other types of criminal behavior. In 1963, a temporary teacher working in a public school did not receive a permanent teaching license from the state board. ${ }^{247}$ Bay, working under a oneyear emergency contract during his last year of college, could not escape his criminal past. During a stint as a night watchman in 1953, Bay took advantage of his position and burglarized many of the buildings he protected. Bay's conviction of grand larceny led to a two-year prison sentence. After an early parole, Bay entered a university program to pursue a teaching degree. Though Bay successfully finished his degree program, the state board decided not to grant him a permanent teaching license because of his criminal past.

The Supreme Court of Oregon favored the state board finding that Bay's prior criminal conduct indicated unfitness to teach. Additionally, the court established that Bay's prior job as a night watchman involved a position of trust, not unlike the role of a teacher. Since Bay abused this trust, he lacked the moral fiber needed to handle another job demanding trust. ${ }^{248}$ The court further stated, "A teacher in a public school is the key factor in teaching by precept and example the subjects of honesty, morality, courtesy, obedience to law, and other issues of a steadying influence which tend to promote and develop as upright and desirable citizenry."249 The court found the state board's decision

\footnotetext{
${ }^{246} I d$.

${ }^{247}$ In re Bay, 378 P.2d 558 (Or. 1963).

${ }^{248}$ Id. at 561 .

${ }^{249} \mathrm{Id}$.
} 
justified, as Bay did not possess the necessary qualities needed in a teacher, including a trustworthy nature.

A generation later, two Massachusetts cases involving off-duty criminal conduct received similar decisions from the same court. The court emphasized the role model theory in both opinions. In Dupree v. School Committee of Boston, ${ }^{250}$ a teacher's indictment for possession of cocaine led to his suspension. Similarly, in Perryman $v$. School Committee, ${ }^{251}$ school officials suspended a teacher, this time for fraudulent behavior. While Dupree and Perryman engaged in different types of off-duty conduct, the court found both violated the public trust placed in school teachers.

In the Dupree decision, the court stated: "From colonial days forward we recognize the unique position of teachers as examples to our youth and charge them to exert their best endeavors to impress on the minds of children and youth committed to their care and instruction the values basic to our society." ${ }^{, 252}$ Comparable language appeared in the Perryman decision, when the court declared: "There are certain forms of employment which carry a position of trust so peculiar to the office and so beyond that imposed by all public service that conduct consistent with this special trust is an obligation of the employment." 253 These courts accepted the prevailing role model theory and held two teachers accountable to a higher standard of moral conduct.

While the facts of each of these cases differed, courts affirmed that these employees were expected to act as role models for students. The fact that their conduct occurred

\footnotetext{
${ }^{250} 446$ N.E.2d 1099 (Mass. App. Ct. 1983).

${ }^{251} 458$ N.E. 2 d 748 (Mass. App. Ct. 1983).

${ }^{252}$ Dupree, 446 N.E.2d at 1101.

${ }^{253}$ Perryman, 458 N.E. $2 d$ at 750.
} 
away from the schoolhouse did not matter. The next section presents cases where employees prevailed in the courts.

\section{Employee Prevails. ${ }^{254}$}

In these cases, courts do not renounce the "teacher-as-role model" theory. Rather the courts assert that the off-duty conduct in question does not harm the teacher's ability to serve as a good role model.

Courts consistently criticize employers' use of the role model theory to support adverse employment decisions against teachers who become pregnant out-of-wedlock. Courts found that bearing a child out-of-wedlock does not constitute immorality, thereby making a teacher a negative role model.

The 1973 case, Andrews v. Drew Municipal Separate School District, ${ }^{255}$ involved a local school board policy barring any unwed person with children. ${ }^{256}$ The superintendent based this policy on a belief that unwed parenthood constituted immoral behavior producing an improper role model. While the employees prevailed on the legal right of equal protection, the court chose to speak to the notion that teachers are role models. The court found the superintendent's fear unviable, and that unwed parents who worked in the

\footnotetext{
${ }^{254}$ See Andrews v. Drew Mun. Separate Sch. Dist., 371 F.Supp. 27 (N.D. Miss. 1973); Avery v. Homewood City Bd. of Educ., 674 F.2d 337 (5th Cir. 1982); Bd. of Educ. v. Jack M, 566 P.2d 602 (Cal. 1977); Bd. of Tr. v. Judge, 123 Cal. Rptr. 830 (Cal. Dist. Ct. App. 1975); Bowalick v. Commw., 840 A.2d 519 (Pa. Commw. Ct. 2004); Brown v. Bathke, 566 F.2d 588 (8th Cir. 1977); Brownsville Area Sch. Dist. v. Alberts, 260 A.2d 765 (Pa. 1970); Burton v. Cascade Sch. Dist., 512 F.2d. 850 (9th Cir. 1975); Comings v. State Bd. of Educ. , 100 Cal. Rptr. 73 (Cal. Ct. App. 1972); Eckmann v. Bd. of Educ., 636 F.Supp. 1214 (N.D. III. 1986); Fielder v. Bd. of Dirs., 662 N.W.2d 371 (Iowa Ct. App. 2003); Fisher v. Snyder, 476 F.2d 375 (8th Cir. 1973); Golden v. Bd. of Educ., 285 S.E.2d 665 (W. Va. 1982); Hale v. Bd. of Educ., 234 N.E.2d 583 (Ohio 1968); In re Termination of Kibbe, 996 P.2d 419 (N.M. 1999); Jackson v. El Dorado Sch.Dist., 48 S.W.3d 558 (Ark. Ct. App. 2001); Laba v. Bd. of Educ., 129 A.2d 273 (N.J. 1957); McNeill v. Pinellas County Sch. Bd., 678 So. $2 d 476$ (Fla. Dist. Ct. App. 1996); N.M. State Bd. of Educ. v. Stoudt, 571 P.2d 1186 (N.M. 1977); Ponton v. Newport News Sch. Bd., 632 F.Supp. 1056 (E.D. Va. 1986); Sherburne v. Sch. Bd., 455 So. 2d 1057 (Fla. Dist. Ct. App. 1984); and Thompson v. Wis. Dep't of Pub. Instruction, 541 N.W.2d 182 (Wis. Ct. App. 1995).

255371 F.Supp. 27 (N.D. Miss. 1973).

${ }^{256}$ See Chapter 4, p. 156 for further discussion regarding Andrews v. Drew Mun. Separate Sch. Dist.
} 
school would not necessarily project an improper image to the school children. "The record is devoid of evidence of proselytization. In the absence of overt, positive stimuli to which children can relate, we are convinced that the likelihood of inferred learning that unwed parenthood is good or praiseworthy, is highly improbable." ${ }^{, 257}$ Just because a teacher becomes pregnant out-of-wedlock does not automatically disclose that teacher's ability to adhere to the role model expectation.

The New Mexico Supreme Court issued a similar response regarding the role model premise in New Mexico State Board of Education v. Stoudt. ${ }^{258}$ When Stoudt, an unmarried high school teacher and coach, became pregnant, school board members asked her to resign. When she refused, board members terminated her contract. Board members cited her immoral conduct and the effect her conduct imposed on the moral climate of the community to justify the termination decision.

The court, though, found Stoudt's termination "arbitrary, unreasonable, and not supported by substantial evidence." ${ }^{, 259}$ Board members found Stoudt's unmarried and pregnant status sufficient to find her immoral and unable to function as a role model. The court, though, contended her status failed to proscribe her ability to function as a role model. In fact, many teachers, students, and community members came to Stoudt's defense, urging that school board members retain her as a teacher. ${ }^{260}$ This would not have occurred, if others viewed Stoudt as a poor role model for students.

\footnotetext{
${ }^{257}$ Andrews, 371 F.Supp. at 35.

${ }^{258} 571$ P.2d 1186 (N.M. 1977).

${ }^{259}$ Id. at 1190 .

${ }^{260}$ Id. at 1189 .
} 
Another court decision related to out-of-wedlock pregnancy emerged nine years after Stoudt. In Ponton v. Newport News School Board, ${ }^{261}$ an unmarried teacher waited a year after giving birth for reinstatement to a teaching position. While school officials thought Ponton's unmarried status would inevitably lead to school sponsored advocacy for outof-wedlock pregnancy, the court disagreed. The court did not find Ponton's conduct indicated any moral defect in her character. Nor did the court assess that Ponton's unwed status would cause an increased advocacy for out-of-wedlock pregnancy. ${ }^{262}$ The court refused to accept that an unmarried yet pregnant teacher would automatically become an undesirable influence on school children. The court found this presumption without merit, and Ponton prevailed.

Courts also reject the "teacher-as-role model" theory in cases involving conduct other than out-of-wedlock pregnancy. A California court failed to accept the teacher-asrole-model theory in Board of Education v. Jack $M{ }^{263}$ Jack M., a tenured elementary school teacher, faced criminal charges after an arrest for homosexual solicitation in a public restroom. While Jack M. claimed emotional distress led to his off-duty conduct, school board members felt the he could no longer provide a behavioral example to young school children. Even when Jack M. produced medical evidence that he was not a homosexual, board members determined that a public sexual offense in and of itself constituted immoral behavior and unfitness to teach.

The court, though, disagreed with the board members' assertion. Instead, the court found that Jack M.'s conduct involved one isolated incident precipitated by undue stress and pressure. Finding Jack M. did not pose a threat to school children or the school

\footnotetext{
${ }^{261} 632$ F.Supp. 1056 (E.D. Va. 1986). See Chapter 4, p. 81 for a further discussion regarding Ponton.

${ }^{262}$ Id. at 1062.

${ }^{263} 566$ P.2d 602 (Cal. 1977).
} 
community, the court stated: "An isolated and aberrant act was not indicative of his ordinary character and ability." ${ }^{264}$ Furthermore, the court found students unlikely to model his behavior, as no one in the school community knew of the incident. "Proof that the act was unknown to his students ... and the absence of evidence that he had by word or example influenced students to engage in improper activity all combine to indicate the insubstantiality of any risk that students would imitate his conduct." ${ }^{, 265}$ The court did not find the board members' concern valid in regard to Jack M.'s diminished ability to be a role model for students as a result of his off-duty conduct.

As recently as 2003, an Iowa court delivered a decision that addressed the role model standard. In Fielder v. Board of Directors, ${ }^{266}$ a tenured female teacher lost her position after a police search of her home turned up drug paraphernalia and one marijuana cigarette. Fielder immediately reported the police search to her supervisor, explaining that the search stemmed from her son's ongoing drug related problems. She told her employer the contraband belonged to her son, even though he no longer lived in her house. Nevertheless, school officials gave Fielder a notice of termination. One of the grounds cited in the notice included poor role model.

This court found that school officials failed to establish Fielder's conduct affected her ability to role model. No evidence existed that Fielder bought, sold, or personally used drugs. Furthermore, the court suspected Fielder did not even know the contraband was in her home. "There is no evidence Fielder conveyed a permissive attitude to her students concerning the use of illegal drugs. As a result of her son's drug problem, which

\footnotetext{
${ }^{264}$ Id. at 703 .

${ }^{265} I d$. at 704.

${ }^{266} 662$ N.W.2d 371 (Iowa Ct. App. 2003).
} 
counseling did not resolve, she ended each of her Friday classes telling her students to stay away from drugs." 267

When a teacher's conduct is such that the ability to role model remains unaffected, courts maintain that the role model argument becomes invalid. But courts consistently confirm the viability of the role model premise, particularly when off-duty conduct involves egregious behavior.

\section{Judicial Use of the Nexus Theory}

The nexus theory requires the establishment of a link between an employee's offduty conduct and an employee's professional duties. Nexus assumes a causal connection exists. ${ }^{268}$ The public education sector began to rely on the nexus theory in 1969 , after the court decision in Morrison v. State Board of Education. ${ }^{269}$ Morrison offered a classic definition for nexus, which courts continue to rely on in the twenty-first century. The establishment of the nexus standard afforded a new way for courts to view off-duty conduct cases. Furthermore, the nexus standard afforded employees more protection from an arbitrary, subjective standard, such as the role model standard. ${ }^{270}$

The nexus theory, like the role model theory, never becomes the basis for a judicial decision. This theory functioned as another filter though which judges and the researcher examined the case law. A consideration of the nexus theory becomes imperative to understand fully the results of the cases. Many employees and employers asserted the

\footnotetext{
${ }^{267}$ Id. at 373.

${ }^{268}$ See Don A. Cozzetto \& Theodore B. Pedeliski, Privacy and the Workplace, 26(4) PUB. PERSONNEL MGMT. 515 (Winter 1997).

${ }^{269} 461$ P.2d 375 (Cal. 1969). See Chapter 2, p. 43 and Chapter 4, p. 85 for a further discussion regarding Morrison.

${ }^{270}$ LOUIS FISHER \& DAVID SCHIMMEL, TEACHERS AND THE LAW 221 (1981).
} 
nexus theory when arguing their cases in court. Courts considered the theory in 79 of the 161 cases.

The employees in these cases involved teachers, administrators, guidance counselors, coaches, and one group of employees. Employees argued all eight constitutionally protected rights that the researcher identified. Employers did not argue freedom of speech or freedom of religion when justifying their adverse decision. The cases, ranging from $1967-2004$, involved all identified types of off-duty conduct (see Table 12).

Table 12: Types of off-duty conduct in nexus cases by prevailing party.

\begin{tabular}{|c|c|c|c|}
\hline Type of Conduct & $\begin{array}{l}\text { Number of } \\
\text { Cases }\end{array}$ & $\begin{array}{c}\text { Employer } \\
\text { Prevails }\end{array}$ & $\begin{array}{c}\text { Employee } \\
\text { Prevails }\end{array}$ \\
\hline Affiliation & 4 & 2 & 2 \\
\hline Alcohol & 4 & 1 & 3 \\
\hline Drugs & 15 & 8 & 7 \\
\hline Fraudulent Behavior & 4 & 4 & \\
\hline Homosexuality & 6 & 2 & 4 \\
\hline Inappropriate Relationship w/Adult & 6 & 4 & 2 \\
\hline Inappropriate Relationship w/Minor & 7 & 5 & 2 \\
\hline Marital Misbehavior & 3 & 1 & 2 \\
\hline Out-of-Wedlock Pregnancy & 5 & & 5 \\
\hline Sexual Exhibitionism/Public Display & 7 & 6 & 1 \\
\hline Theft/Robbery & 5 & 3 & 2 \\
\hline Other Criminal Conduct & 10 & 8 & 2 \\
\hline Other Non-Criminal Conduct & 3 & 2 & 1 \\
\hline Totals & 79 & 46 & 33 \\
\hline
\end{tabular}


Employer Prevails. ${ }^{271}$

While Morrison presented the classic standard for nexus, the researcher identified one case prior to Morrison where the judiciary considered a nexus between the off-duty conduct and professional effectiveness, Sarac v. State Board of Education. ${ }^{272}$ A 1967 case from California, Sarac resembled Morrison in that the case involved a homosexual male teacher. Sarac's homosexual activity resulted in a sexual encounter with another man on a public beach leading to an arrest on charges of public indecency. Sarac refrained from contesting the criminal charges, claiming that course of action afforded a dismissal of more serious charges. Sarac admitted to school officials that he had a

\footnotetext{
${ }^{271}$ See Baker v. Sch. Dist., 371 A.2d 1028 (Pa. Commw. Ct. 1977); Barringer v. Caldwell County Bd. of Educ., 473 N.E.2d 435 (N.C. Ct. App. 1996); Bertrand v. N.M. State Bd. of Educ., 544 P.2d 1176 (N.M. Ct. App. 1976); C.F.S. v. Mahan, 934 S.W.2d 615 (Mo. Ct. App. 1996); Chicago Bd. of Educ. v. Payne, 430 N.E.2d 310 (Ill. App. Ct. 1981); Crumpler v. State Bd. of Educ., 594 N.E.2d 1071 (Ohio Ct. App. 1991); Denton v. S. Kitsap Sch. Dist., 516 P.2d 1080 (Wash. Ct. App. 1973); Deshields v. Chester-Upland Sch. Dist., 505 A.2d 1080 (Pa. Commw. Ct. 1986); Dupree v. Sch. Comm. of Boston, 446 N.E.2d 1099 (Mass. App. Ct. 1983); Feagin v. Everett, 652 S.W.2d 839 (Ark Ct. App. 1983); Gaylord v. Tacoma Sch. Dist., 559 P.2d 1340 (Wash. 1977); Gish v. Bd. of Educ., 366 A.2d 1337 (N.J. 1976); Governing Bd. v. Brennan, 95 Cal. Rptr. 712 (Cal. Ct. App. 1971); Hainline v. Bond, 824 P.2d 959 (Kan. 1992); Hamm v. Poplar Bluff Sch. Dist., 955 S.W.2d 27 (Mo. Ct. App. 1997); Hoffman v. State Bd. of Educ., 763 N.E.2d 210 (Ohio Ct. App. 2001); Homer v. Commw., 458 A.2d 1059 (Pa. Commw. Ct. 1983); In re Appeal of Morrill, 765 A.2d 699 (N.H. 2001); In re Grossman, 316 A.2d 39 (N.J. Super. Ct. App. Div. 1974); In re Thomas, 926 S.W.2d 163 (Mo. Ct. App. 1996); Kenai Peninsula Borough Bd. of Educ. v. Brown, 691 P.2d 1034 (Alaska 1984); Lang v. Lee, 639 S.W.2d 111 (Mo. Ct. App. 1982); Logan v. Warren County Bd. of Educ., 549 F.Supp. 145 (S.D. Ga. 1982); Matter of Shelton, 408 N.W.2d 594 (Minn. Ct. App. 1987); Meinhold v. Clark County Sch. Dist., 506 P.2d 420 (Nev. 1073); Melzer v. Bd. of Educ., 336 F.3d 185 (2nd Cir. 2003); Mescia v. Berry, 406 F.Supp. 1181 (S.C. 1974); Perryman v. Sch. Comm., 458 N.E.2d 748 (Mass. App. Ct. 1983); Pettit v. State Bd. of Educ., 513 P.2d 889 (Cal. 1973); Purifoy v. State Bd. of Educ., 106 Cal. Rptr. 201 (Cal. Ct. App. 1973); Purvis v. Marion County Sch. Bd., 766 So. 2 d 492 (Fla. Dist. Ct. App. 2000); Ross v. Springfield Sch. Dist., 691 P.2d 509 (Or. Ct. App. 1984); Sarac v. State Bd. of Educ., 57 Cal. Rptr. 69 (Cal. Ct. App. 1967); Satterfield v. Bd. of Educ., 556 N.W.2d 888 (Mich. Ct. App. 1996); Shipley v. Salem Sch. Dist., 669 P.2d 1172 (Or. Ct. App. 1983); Skripchuk v. Austin, 379 A.2d 1142 (Del. Super. Ct. 1977); Stelzer v. State Bd. of Educ., 595 N.E.2d 489 (Ohio Ct. App. 1991); Sullivan v. Meade Indep. Sch. Dist., 530 F.2d 799 (8th Cir. 1975); Tomerlin v. Dade County Sch. Bd., 318 So. 2 d 159 (Fla. Dist. Ct. App. 1975); Vogulkin v. State Bd. of Educ., 15 Cal Rptr. 335 (Cal. Dist. Ct. App. 1961); Walton v. Turlington, 444 So. 2d 1082 (Fla. Dist. Ct. App. 1984); Watson v. State Bd. of Educ., 90 Cal. Rptr. 468 (Cal. Ct. App. 1971); Winters v. Ariz. Bd. of Educ., 83 P.3d 1114 (Ariz. Ct. App. 2004); Wishart v. McDonald, 367 F.Supp. 530 (D. Mass. 1973); Woo v. Putnam County Bd. of Educ., 504 S.E.2d 644 (W. Va. 1998); and Yanzick v. Sch. District, 641 P.2d 431 (Mont. 1982).

27257 Cal. Rptr. 69 (Cal. Ct. App. 1967).
} 
"homosexual problem" since the age of twenty. The State Board began certification revocation proceedings against Sarac finding his actions involved moral turpitude.

Sarac claimed no rational connection existed between his conduct on the beach and his position as a teacher. The court, referring to an "obvious rational connection," found Sarac's off-duty conduct clearly related to his professional responsibilities. ${ }^{273}$ While the term nexus did not appear in this decision, the court's language encompassed the major component of nexus.

Five years after the Morrison ruling, a New Jersey court found a nexus existed between a teacher's off-duty conduct and his teaching position. In re Grossman ${ }^{274}$ involved a teacher who underwent a sex change operation. School officials found the potential for his behavior to create a negative impact on students too great and terminated his position. ${ }^{275}$ Specifically in regard to a nexus between Grossman's conduct and his teaching position, the court asserted his continued presence in the classroom would present a negative effect on the mental health of students. Grossman's operation changed his physical attributes to those of a woman. "When teacher's presence in the classroom would create a potential for psychological harm to the students, the teacher is unable properly to fulfill his or her role.,276

Sometimes courts find a nexus between off-duty conduct and employment when the conduct affects other employees more than the students. Thirteen years after Grossman, a Minnesota court found a nexus existed between a teacher's off-duty theft activity and his

\footnotetext{
${ }^{273}$ Id. at 72.

${ }^{274} 316$ A.2d 39 (N.J. App. Div. 1974).

${ }^{275}$ See Chapter 4, p. 154 for further facts and discussion on In re Grossman.

${ }^{276}$ Grossman, 316 A.2d at 49.
} 
teaching position. ${ }^{277}$ Shelton belonged to a corporate partnership with two other teachers to sell computer equipment. Shelton's partners discovered he made unauthorized withdrawals from the corporation's bank account over a two-year period and reported Shelton to the police. Knowledge of Shelton's criminal activity spread throughout his school and tensions began to rise. Faculty in particular became divided over Shelton's criminal activity and whether Shelton should remain employed. School officials discharged Shelton, citing immoral conduct, conduct unbecoming a teacher, and "irremediable deterioration of faculty relations."278

The court upheld the school's decision to terminate Shelton finding a clear nexus established between Shelton's criminal activity and the disruption in the school environment. While the court agreed with school officials that Shelton's behavior caused no particular harm to students, the court further determined Shelton's conduct did impact other employees. "Shelton's continued presence in this small school district will result in faculty disorder and an unsatisfactory learning environment."279 The court supported Shelton's termination, finding that school officials clearly established a rational nexus between his off-duty conduct and his teaching position.

In 1996, a similar judicial outcome emerged. A Missouri court found a teacher's offduty conduct contrary to the message school officials expected her to impart in the classroom, concluding the establishment of a nexus. In re Thomas ${ }^{280}$ involved a female teacher who, in the midst of an argument, opened gun fire on her estranged husband and his girlfriend. In concert with the criminal proceedings, school board members held a

\footnotetext{
${ }^{277}$ Matter of Shelton, 408 N.W.2d 594 (Minn. Ct. App. 1987).

${ }^{278} I d$. at 596.

${ }^{279} I d$ at 598.

${ }^{280} 926$ S.W.2d 163 (Mo. Ct. App. 1996).
} 
hearing to consider Thomas' dismissal. Board members considered that Thomas' retention in the classroom would send a mixed message to students contravening the school district's policy on non-violence. Finding her behavior immoral, board members voted to terminate Thomas.

Thomas, though, contended no evidence existed to show a nexus existed between her off-duty conduct and the performance of her duties. She argued that school officials could only consider immoral conduct that occurred on school grounds or directly involved students. The court, though, agreed with school officials and found that intentional shooting of another, without legal justification, created a clear nexus regardless of where the shooting occurred. "The use of violence by a teacher to solve personal problems was likely to have an adverse effect on her students by confusing the violence free message promoted by the school board." ${ }^{281}$ Furthermore, the court indicated that Thomas' conduct substantiated the board member's termination decision without a showing of actual harm to students. ${ }^{282}$ A clear nexus existed between Thomas' shooting spree and her professional duties.

In early 2004, an Arizona court found a teacher's series of off-duty, violent incidents constituted a rational nexus to his teaching position. ${ }^{283}$ Winters repeatedly began verbal and physical altercations with his neighbors. Of the five known incidents, two involved teenagers. During one of the incidents, Winters aimed and shot a pistol toward his neighbor's house. Winters faced multiple criminal charges as a result of the incidents. The Arizona State Board of Education revoked Winters' teaching certificate based on immoral and unprofessional conduct.

\footnotetext{
281 Id. at 166.

282 Id.

${ }^{283}$ Winters v. Ariz. Bd. of Educ., 83 P.3d 1114 (Ariz. Ct. App. 2004).
} 
Winters claimed that no evidence existed to support the findings of the state board. Furthermore, Winters asserted that his behavior did not affect the daily operation of the school or adversely impact his students, and, therefore, no nexus existed. Simply put, he argued a criminal charge alone did not create a nexus between the off-duty conduct and professional responsibilities. The court, though, agreed with state board members' contention that a clear nexus emerged from Winters' off-duty conduct. The court declined to limit immoral and unprofessional conduct to student-teacher interactions and considered his pattern of criminal conduct. "We conclude that Winters' undisputed conduct did relate to his fitness as a teacher. The evidence established his tendency to react with violence and aggression. The fact that these incidents did not occur on school premises does not negate the gravity of Winters' behavior." ${ }^{284}$ The state officials possessed a rational interest and concern in Winters' conduct, as his position entailed daily contact with students. This concern provided the basis to prevent a violent disruption at school. "There may be conduct which by itself gives rise to reasonable inferences of unfitness to teach or from which an adverse impact on students can reasonably be assumed."285 The court found that state officials established a rational nexus, even though no specific harm to students occurred.

A similar judicial outcome emerged in 1984, when the Alaska Supreme Court declared the presumption of a nexus can support an adverse employment decision. In Kenai Peninsula Borough Board of Education v. Brown, ${ }^{286}$ a tenured teacher's criminal conviction led to his dismissal. Brown's off-duty conduct included diverting electricity from the local power company so that the meter would not track his usage. While

\footnotetext{
${ }^{284} \mathrm{Id}$. at 1120 .

${ }^{285} \mathrm{Id}$.

${ }^{286} 691$ P.2d 1034 (Alaska 1984).
} 
Brown's criminal conduct happened while off-duty, school officials terminated his position.

Applying the nexus test, this court found Brown's behavior did relate to his teaching position. School officials provided substantial evidence that Brown's activity involved moral turpitude. "The finding that a crime involving moral turpitude has been committed raises at least a presumption that there is a nexus between the teacher's act and the teacher's fitness to teach." ${ }^{\text {287 }}$ The court found the presumption of a nexus enough and school officials did not need to show Brown's behavior caused an actual impact. Brown's criminal activity in and of itself provided a rational connection to his professional responsibilities.

Employers can also demonstrate a nexus exists between an employee's off-duty conduct and the job when the external community becomes aware of the employee's conduct. In these instances, courts often affirm a nexus on the basis of external knowledge of the conduct.

In Yanzick v. School District, a tenured male teacher faced termination due to his cohabitation with a woman out-of-wedlock. ${ }^{288}$ School officials terminated him when Yanzick's living arrangements became so well known inside and outside of the school. Yanzick argued school officials failed to establish a nexus between his off-duty conduct and his teaching position. Relying on Morrison, the court determined Yanzick's behavior did not possess a private quality. "Yanzick's conduct was not some form of private conduct unknown to the community, but was conduct broadly known throughout the

\footnotetext{
${ }^{287}$ Id. at 1041 .

${ }^{288} 641$ P.2d 431 (Mont. 1982).
} 
community." ${ }^{289}$ The notoriety Yanzick's behavior generated affected his ability to maintain his professional duties and responsibilities thereby confirming the existence of a rational nexus between his conduct and his job.

\section{Employee Prevails. ${ }^{290}$}

Employees often argue that no nexus exists between their off-duty conduct and their professional responsibilities in a public $\mathrm{P}-12$ school setting. When courts address the issue of nexus, or lack thereof, whether a rational connection exists between the off-duty conduct and a person's job becomes the determinative factor.

\section{In 1981, the Washington state Supreme Court found in Hoagland v. Mount Vernon} School District ${ }^{291}$ that criminal behavior, in and of itself, did not immediately establish a nexus. Hoagland happened to buy a stolen motorcycle and ended up charged with grand larceny. Though Hoagland claimed he thought the purchase was legitimate, officials moved to terminate him, finding his criminal activity harmful to the teacher-student

\footnotetext{
${ }^{289}$ Id. at $441-442$.

${ }^{290}$ See Allen v. Bd. of Educ., 584 S.W.2d 408 (Ky. Ct. App. 1979); Baker v. Sch. Bd., 450 So. 2d 1194 (Fla. Dist. Ct. App. 1984); Bd. of Educ. v. Jack M., 566 P.2d 602 (Cal. 1977); Bd. of Trs. v. Judge, 123 Cal. Rptr. 830 (Cal. Dist. Ct. App. 1975); Bogart v. Unified Sch. Dist., 432 F.Supp. 895 (D. Kan. 1977); Burton $v$. Cascade Sch. Dist., 512 F.2d. 850 (9th Cir. 1975); Clark v. Sch. Bd., 596 So. 2 d 735 (Fla. Dist. Ct. App. 1992); Comings v. State Bd. of Educ., 100 Cal. Rptr. 73 (Cal. Ct. App. 1972); Drake v. Covington County Bd. of Educ., 371 F.Supp. 974 (M.D. Ala. 1974); Eckmann v. Bd. of Educ., 636 F.Supp. 1214 (N.D. Ill. 1986); Erb v. Iowa State Bd. of Pub. Instruction, 216 N.W.2d 339 (Iowa 1974); Fielder v. Bd. of Dirs., 662 N.W.2d 371 (lowa Ct. App. 2003); Garcia v. State Bd. of Educ., 694 P.2d 1371 (N.M. Ct. App. 1984); Golden v. Bd. of Educ., 285 S.E.2d 665 (W. Va. 1982); Hankla v. Governing Bd., 120 Cal. Rptr. 827 (Cal. Ct. App. 1975); Hoagland v. Mount Vernon Sch. Dist., 623 P.2d 1156 (Wash. 1981); In re Termination of Kibbe, 996 P.2d 419 (N.M. 1999); Jarvella v. Willoughby-Eastlake City Sch. Dist., 233 N.E.2d 143 (Ohio Misc. 1967); Lindgren v. Bd. of Trs., 558 P.2d 468 (Mont. 1976); McNeill v. Pinellas County Sch. Bd., 678 So. 2d 476 (Fla. Dist. Ct. App. 1996); Morrison v. State Bd. of Educ., 461 P.2d 375 (Cal. 1969); N.M. State Bd. of Educ. v. Stoudt, 571 P.2d 1186 (N.M. 1977); Overton v. Goldsboro City Bd. of Educ., 283 S.E.2d 495 (N.C. 1981); Ponton v. Newport News Sch. Bd., 632 F.Supp. 1056 (E.D. Va. 1986); Reinhardt v. Bd. of Educ., 311 N.E.2d 710 (IIl. App. Ct. 1974); Rogliano v. Fayette County Bd. of Educ., 347 S.E.2d 220 (W. Va. 1986); Sherburne v. Sch. Bd., 455 So. $2 d 1057$ (Fla. Dist. Ct. App. 1984); Sublett v. Sumter County Sch. Bd., 664 So. 2d 1178 (Fla. Dist. Ct. App. 1995); Thompson v. Southwest Sch. Dist., 483 F.Supp. 1170 (W.D. Mo. 1980); Thompson v. Wis. Dep't of Pub. Instruction, 541 N.W.2d 182 (Wis. Ct. App. 1995); Turk v. Franklin Special Sch. Dist., 640 S.W.2d 218 (Tenn. 1982); and Weaver v. Nebo Sch. Dist., 29 F.Supp.2d 1279 (D. Utah 1998).

${ }^{291} 623$ P.2d 1156 (Wash. 1981).
} 
relationship. Hoagland took his case straight to the judicial system, bypassing a hearing with his employer.

The lower court granted summary judgment to the school district. On appeal, Hoagland argued no nexus existed between the criminal matter and his position. The court asserted that school officials could not establish nexus on criminal activity alone. "Without an actual showing of impairment to teaching, simply labeling an instructor as a convicted felon will not justify a discharge."292 The court, relying on Morrison, considered several factors in assessing whether Hoagland's off-duty conduct created a nexus with his job, including the seriousness of the offense and the possibility of repetition. ${ }^{293}$ The court determined that Hoagland deserved a hearing on the matter, as Hoagland claimed he did not know he purchased stolen property. Furthermore, the school district provided no evidence that an adverse reaction occurred toward Hoagland as a result of his criminal trouble. "The record contains no allegations that the facts underlying the conviction had any adverse effect on his ability or effectiveness as a teacher."294 The court found no nexus between the off-duty conduct and Hoagland's ability to maintain his professional duties.

Two years later, a Florida court declined to accept an employer's assertion of nexus, when a single teacher lived together with her boyfriend. ${ }^{295}$ Many people, including students, knew about Sherburne's living situation. Sometimes her boyfriend came by the school and visited her class. Sherburne received several warnings from administrators who believed that her behavior lacked good moral character and could affect students.

\footnotetext{
${ }^{292} I d$. at 1159 .

${ }^{293} \mathrm{Id}$.

${ }^{294}$ Id. at 1160.

${ }^{295}$ Sherburne v. School Board, 455 So. $2 d 1057$ (Fla. Dist. Ct. App. 1984). See Chapter 4, p. 149 for further discussion of Sherburne.
} 
After teaching for three years, the superintendent recommended Sherburne for a continuing contract. The board members, though, refused his request.

The court recognized that the cohabitation issue likely sparked many debates regarding Sherburne's morality and character. The court, though, insisted that Sherburne's cohabitation did not justify the negative contract decision. "The record is devoid of evidence that any conduct by appellant had such an effect on her students, or that her effectiveness as a teacher had been impaired." ${ }^{, 296}$ School board members failed to establish a nexus between Sherburne's off-duty conduct and her position.

Occasionally, employers argue the relationship between off-duty conduct and an employee's job creates a nexus when the conduct generates notoriety and publicity in the larger community. Courts, though, reject this argument, unless the notoriety proves substantial and harmful to the employee's continued effectiveness within the school setting.

In 1986, one such case emerged involving the arrest of a tenured teacher for marijuana possession. ${ }^{297}$ School officials suspended Rogliano during the criminal proceedings and later dismissed him, even though the court dismissed the criminal charges. Board members argued that community members knew Rogliano used drugs and his arrest and subsequent publicity related to the arrest enhanced this negative characterization.

In determining whether or not a nexus existed, the court considered whether Rogliano's behavior affected his job. While the court found that Rogliano's arrest did incur a lot of publicity, school board members failed to show how this publicity affected

\footnotetext{
${ }^{296} I d$. at 1061.

${ }^{297}$ Rogliano v. Fayette County Bd. of Educ., 347 S.E.2d 220 (W. Va. 1986).
} 
his ability to perform his job. No nexus existed between Rogliano's arrest and his ability to maintain his job. ${ }^{298}$ Furthermore, the court found the school board members created much of the publicity related to Rogliano's conduct.

In 1999, a New Mexico case in 1999 failed to convince the court that a nexus existed between the off-duty conduct of a teacher and coach involving alcohol and his professional responsibilities. ${ }^{299}$ Kibbe's arrest for DUI created much publicity. The superintendent claimed that Kibbe's arrest caused a public scandal and the majority of community members wanted Kibbe removed from his position. School officials, finding his conduct compromised his effectiveness as a teacher and a coach, terminated Kibbe.

While a great deal of publicity surrounded Kibbe's arrest, the court determined that school officials failed to demonstrate how the incident affected Kibbe's effectiveness as a teacher. The court found school officials merely surmised that Kibbe could no longer maintain effectiveness as a teacher and a coach. "There is no evidence that a reasonable mind would regard as adequate to support the conclusion that Kibbe's actions prevented the proper performance of his required teaching and coaching duties.",300

Courts sometimes use the nexus standard as a means to proscribe the use of the role model theory to justify adverse employment decisions. Finding the role model theory an essentially subjective standard, courts demand to see a clear and rational connection between an employee's off-duty conduct and the employee's job. The researcher identified three such cases. ${ }^{301}$

\footnotetext{
${ }^{298}$ Id. at 224.

${ }^{299}$ In re Termination of Kibbe, 996 P.2d 419 (N.M. 1999). See Chapter 4, p. 470 for a further discussion related to Kibbe.

${ }^{300}$ Id. at 423.

${ }^{301}$ See Bd. of Trs. v. Judge, 123 Cal. Rptr. 830 (Cal. Dist. Ct. App. 1975); Erb v. Iowa State Bd. of Pub. Instruction, 216 N.W.2d 339 (Iowa 1974); and Thompson v. Wis. Dep't of Pub. Instruction, 541 N.W.2d 182 (Wis. Ct. App. 1995).
} 
In 1974, the Iowa State Board of Education revoked the teaching credentials of a tenured male teacher. ${ }^{302}$ The revocation stemmed from Erb's adulterous affair with a local woman. When the woman's husband confronted Erb, he admitted the affair to his wife and local school officials. While Erb offered to resign his position, school officials asked him to remain. The state board, though, found out about Erb's conduct and began license revocation proceedings on grounds of moral turpitude.

The state board asserted that Erb's behavior, in and of itself, established his unfitness to teach. The court refuted this assertion. The court maintained that a revocation decision demanded that the conduct in question adversely impact the teacher-student relationship. Otherwise, "it would vest the board with unfettered power to revoke the certificate of any teacher whose personal, private conduct incurred its disapproval regardless of its likely or actual effect upon his teaching." ${ }^{303}$ The personal moral views of board members cannot fairly establish unfitness of a teacher. The court demanded a rational nexus must exist to justify the revocation, and Erb's conduct failed to create such a nexus.

A year after Erb, a California court also considered the issue of nexus in Board of Trustees v. Judge. ${ }^{304}$ Police arrested Judge, a tenured teacher, for cultivation and possession of marijuana, which led to a criminal conviction. Judge claimed he found the marijuana plant on a walk one day and brought the plant to his house. Judge further claimed he did not recognize the plant as a marijuana plant. School officials terminated Judge on grounds of moral turpitude and he brought suit against the school board members.

\footnotetext{
${ }^{302} \operatorname{Erb}, 216$ N.W.2d 339 (Iowa 1974).

${ }^{303}$ Id. at 343 .

304123 Cal. Rptr. 830 (Cal. Dist. Ct. App. 1975).
} 
During the court proceedings, school officials argued that teachers must maintain high moral standards. Furthermore, the criminal conviction in and of itself involved an act of moral turpitude which justified the termination decision. The court disagreed with this premise. Not only did the court find a conviction in and of itself insufficient to assert unfitness to teach, the court also stated: "There must be a nexus between the teacher's conduct and his usefulness to the school district. The evidence is insufficient to establish any such unfitness." 305 The court saw Judge as "a curious teacher" who just happened to bring a plant home. "It regarded the growing of one plant of marijuana as an obviously different category than cases involving sexual misconduct, homosexuality, fraud, dishonesty, and similar conduct. No student was involved in the offense and the offense did not ... take place on school premises." ${ }^{306}$ School officials failed to establish a rational nexus between Judge's off-duty conduct and his teaching duties.

Another court decision articulated that employers must establish a nexus between off-duty conduct and an employee's professional responsibilities. Although twenty years separate Thompson v. Wisconsin Department of Public Instruction ${ }^{307}$ from Judge, a similar nexus standard required by the courts emerged from both decisions. Thompson engaged in two instances of public sex. The first incident led to a disorderly conduct charge, while the second incident led to a conviction on fourth degree sexual assault. Both incidents involved homosexual activity. The Wisconsin Department of Education held a hearing and the hearing officer found no nexus existed between the criminal conduct and Thompson's ability to perform his job. The department disregarded the hearing officer's finding and revoked Thompson's teaching license on grounds of

\footnotetext{
${ }^{305} I d$. at 836.

${ }^{306} \mathrm{Id}$. at 833 .

${ }^{307} 541$ N.W.2d 182 (Wis. Ct. App. 1995).
} 
immoral conduct. Department officials claimed a nexus existed, becuase Thompson could no longer serve as a role model to students.

This court found department officials improperly relied on the role model theory. "Applying a role model standard reflecting community attitudes effectively eliminates the nexus requirement. All cases of immoral conduct are by definition offensive to community standards." ${ }^{308}$ The court also expressed concern that the role model theory could never be applied consistently or evenly. "A standard based on community attitudes cannot be applied consistently. Community attitudes are difficult to measure, they vary from community to community, and they change over the course of time."309 Finding that department officials used a nebulous standard on which to base the revocation decision, the court declared that they failed to establish a nexus. Thompson's offense took a back seat to the community reaction to the offense. State officials failed to examine what effect, if any, Thompson's conduct produced on his ability to perform his professional responsibilities. The court asserted that officials must determine if a relationship "exists between the immoral conduct and the health, welfare, safety or education of any pupil." 310 The appropriateness of a revocation decision depends on the existence of a nexus. While the state department officials failed to substantiate that a nexus existed, the court remanded the case to the department for a further hearing where state officials could apply the proper nexus standard.

\footnotetext{
${ }^{308} I d$. at 186.

${ }^{309}$ Id.

${ }^{310} I d$.
} 


\section{Data Drawn From Collected Cases}

The researcher captured identical data from each case when examining the body of case law related to the research question. The data afforded an overall setting in which to view the relevant case law. The additional data afforded an opportunity to assess specific commonalities or relationships among the cases.

The research led to 161 cases where employees faced discipline as a result of their off-duty conduct. Employees prevailed in these cases on seventy occasions or forty-three percent of the time, while employers prevailed in the remaining ninety-one cases or fiftyseven percent of the time (see Table 13). No employees prevailed in the cases involving fraudulent behavior. On the other hand, no employers prevailed in the cases concerning pregnancy out-of-wedlock. The other types of off-duty conduct discovered in the case law had instances of employers prevailing and employees prevailing.

Table 13: Prevailing party in cases involving criminal and non-criminal off-duty conduct.

\begin{tabular}{|c|c|c|c|}
\hline & $\begin{array}{l}\text { Total \# } \\
\text { of cases }\end{array}$ & $\begin{array}{c}\text { Employer } \\
\text { Prevails }\end{array}$ & $\begin{array}{c}\text { Employee } \\
\text { Prevails }\end{array}$ \\
\hline Criminal Conduct* & 104 & $\begin{array}{ll}71 & (70 \%)\end{array}$ & $33 \quad(30 \%)$ \\
\hline Non-criminal/Personal Conduct* & 57 & $(35 \%)$ & $(65 \%)$ \\
\hline
\end{tabular}

${ }^{*}$ Criminal conduct included alcohol, drugs, fraudulent behavior, inappropriate relationships with minors, sexual exhibitionism and public display, theft/robbery, and other criminal conduct. Non-criminal/personal conduct included affiliation, homosexuality, inappropriate relationships with adults, marital misbehavior, pregnancy out of wedlock, and other non-criminal behavior.

Male employees received discipline for off-duty conduct twice as many times as female employees. The employees disciplined included 105 males, 51 females, and 5 groups of employees (see Table 14).

Table 14: Employee gender in the off-duty cases.

\begin{tabular}{|c|c|c|}
\hline Male & Female & Group of Employees \\
\hline 105 & 51 & 5 \\
\hline $65 \%$ & $32 \%$ & $3 \%$ \\
\hline
\end{tabular}


All the groups of employees included male and female employees, except for one case involving only female employees. ${ }^{311}$

Employees disciplined for off-duty conduct held teaching positions almost $90 \%$ of the time. The employees in the off-duty conduct cases included teachers, administrators, guidance counselors, coaches, staff, and other positions. No cases involved an athletic director. In all the cases involving coaches, the coaches also held a teaching position within the same school (see Table 15).

Table 15: Employee positions indicated in the off-duty conduct cases.

\begin{tabular}{|l|ll|}
\hline Employee Position & \multicolumn{2}{|c|}{ Number } \\
\hline Teacher & 140 & $(87 \%)$ \\
\hline Administrator & 9 & $(5 \%)$ \\
\hline Guidance Counselor & 2 & $(1 \%)$ \\
\hline Coach & 7 & $(4 \%)$ \\
\hline Athletic Director & 0 & \\
\hline Staff & 4 & $(2 \%)$ \\
\hline Other & 3 & $(1 \%)$ \\
\hline
\end{tabular}

In regard to employee tenure status, sixty-eight employees had tenure, thirty-three had no tenure, and sixty of the cases did not identify the tenure status of the employee. The researcher attempted to identify the race for each employee but with few results. Only nine cases identified race: six cases specified the employee as African American, two cases specified a Caucasian employee, and one case specified an Hispanic employee. The remaining 152 cases did not identify the race of the employee. No case identified whether an employee was a union member.

${ }^{311}$ See Andrews v. Drew Mun. Separate Sch. Dist., 371 F.Supp. 27 (N.D. Miss. 1973). 
The researcher found cases emerging from the following types of public schools:

elementary, middle school, high school, and mixed grade. Sixty-eight cases did not identify the school level (see Table 16).

Table 16: Cases by school level.

\begin{tabular}{|l|l|}
\hline School level & Number of Cases \\
\hline Elementary & 28 \\
\hline Middle & 14 \\
\hline High & 41 \\
\hline Mixed Grade & 10 \\
\hline Not Stated & 68 \\
\hline \multicolumn{1}{|c|}{ Total } & \\
\hline
\end{tabular}

The researcher also compared the type of off-duty conduct to school level (see Table 17).

Table 17: Type of off-duty conduct by school level.

\begin{tabular}{|c|c|c|c|c|c|}
\hline Type of Off-Duty Conduct & $\begin{array}{l}\text { Elementary } \\
\text { School }\end{array}$ & $\begin{array}{l}\text { Middle } \\
\text { School }\end{array}$ & $\begin{array}{l}\text { High } \\
\text { School }\end{array}$ & \begin{tabular}{|l|} 
Mixed \\
Grade \\
School \\
\end{tabular} & $\begin{array}{c}\text { Not } \\
\text { Stated }\end{array}$ \\
\hline Affiliation & 1 & & 4 & & 8 \\
\hline Alcohol & 1 & & 3 & 2 & 3 \\
\hline Drugs & 3 & 5 & 9 & 2 & 14 \\
\hline Fraudulent Behavior & 2 & & & & 4 \\
\hline Homosexuality & 3 & & 4 & & 3 \\
\hline Inappropriate Relationship w/Adult & 2 & 3 & 2 & & 2 \\
\hline Inappropriate Relationship w/Minor & 2 & 1 & 2 & & 6 \\
\hline Marital Misbehavior & 2 & & 3 & 1 & 1 \\
\hline Pregnancy Out of Wedlock & 2 & 1 & 1 & 1 & 4 \\
\hline $\begin{array}{l}\text { Sexual Exhibitionism/Decadence/Public } \\
\text { Display }\end{array}$ & 3 & 2 & 1 & 1 & 3 \\
\hline Theft/Robbery & 3 & & 2 & 1 & 5 \\
\hline Other Criminal Conduct & 2 & 2 & 8 & 1 & 11 \\
\hline Other Non-Criminal Conduct & 2 & & 2 & 1 & 4 \\
\hline Totals & 28 & 14 & 41 & 10 & 68 \\
\hline
\end{tabular}

Employees suffered the following losses from employer discipline over their off-duty conduct: termination, nonrenewal, license revocation, involuntary transfer, suspension with pay, suspension without pay, receiving a negative review in the personnel file, and other unidentified losses. No identified case involved an employee receiving a demotion (see table 18). 
Table 18: Employee loss sustained and prevailing party.

\begin{tabular}{|c|c|c|c|}
\hline Employee Loss & Total \# & $\begin{array}{l}\text { Employer } \\
\text { Prevailed }\end{array}$ & $\begin{array}{l}\text { Employee } \\
\text { Prevailed }\end{array}$ \\
\hline Maximum Loss* & $134 \quad(83 \%)$ & $78 \quad(58 \%)$ & $56 \quad(42 \%)$ \\
\hline Minimum Loss* & $(17 \%)$ & $(48 \%)$ & $(52 \%)$ \\
\hline Totals & 161 & 91 & 70 \\
\hline
\end{tabular}

*Maximum loss included termination, nonrenewal, and license revocation. Minimum loss included involuntary transfer, suspension with or without pay, receiving a negative review in the personnel file, and other unidentified losses.

The cases related to the research question came from both federal and state courts.

Federal courts heard 38 of the cases while state courts reviewed the remaining 123 cases (see Table 19). Of the seventeen federal appeals cases, only the first, third, eleventh, and federal circuits did not render a relevant decision.

Table 19: Cases by courts.

\begin{tabular}{|l|c|}
\hline Court & Number of Cases \\
\hline Federal Circuit Court & 17 \\
\hline Federal District Court & 21 \\
\hline State - Highest Court & 39 \\
\hline State - Intermediate Court & 72 \\
\hline State - Trial Court & 12 \\
\hline
\end{tabular}

Thirty-nine of the 161 cases received only one judicial hearing. In those cases, the employee prevailed fifty-nine percent of the time. When cases received multiple hearings, employers prevailed at a higher rate than employees at the first hearing and the final hearing (see Table 20).

Table20: Prevailing party by hearing level.

\begin{tabular}{|r|c|cc|cc|}
\hline Number of Judicial Hearings & Total \# & \multicolumn{2}{|c|}{$\begin{array}{c}\text { Employer } \\
\text { Prevails }\end{array}$} & \multicolumn{2}{|c|}{$\begin{array}{c}\text { Employee } \\
\text { Prevails }\end{array}$} \\
\hline Outcomes w/ One Hearing & 39 & 16 & $(41 \%)$ & 23 & $(59 \%)$ \\
\hline Outcomes w/ Multiple Hearings & 122 & & & & \\
\hline Level One Outcome & & 78 & $(64 \%)$ & 44 & $(36 \%)$ \\
\hline Final Outcome & & 75 & $(62 \%)$ & 47 & $(38 \%)$ \\
\hline Totals & 161 & 91 & 70 & \\
\hline
\end{tabular}


The researcher identified cases related to the research question from forty-two states and the District of Columbia (see Table 21). California courts considered the issue of offduty conduct for P-12 public school personnel more than any other jurisdiction, with twenty-one cases identified. The researcher did not identify any cases from the following states: Colorado, Hawaii, Idaho, Maryland, Maine, North Dakota, Rhode Island, and Vermont.

Table 21: Cases by state.

\begin{tabular}{|cc|cc|cc|}
\hline State & $\#$ & State & $\#$ & State & $\#$ \\
\hline AL & 5 & LA & 1 & OK & 1 \\
\hline AK & 2 & MA & 6 & OR & 6 \\
\hline AZ & 2 & MI & 1 & PA & 16 \\
\hline AR & 1 & MN & 2 & SC & 4 \\
\hline CA & 21 & MS & 2 & SD & 1 \\
\hline CT & 1 & MO & 6 & TN & 2 \\
\hline DE & 1 & MT & 2 & TX & 2 \\
\hline DC & 1 & NE & 2 & UT & 2 \\
\hline FL & 12 & NV & 2 & VA & 2 \\
\hline GA & 2 & NH & 1 & WA & 3 \\
\hline IL & 9 & NJ & 5 & WV & 5 \\
\hline IN & 1 & NM & 4 & WI & 1 \\
\hline IA & 3 & NY & 5 & WY & 2 \\
\hline KA & 1 & NC & 2 & & \\
\hline KY & 3 & OH & 8 & & \\
\hline
\end{tabular}

\section{Summary}

The researcher identified a total of 161 on-point cases. An examination of each case occurred to gather the appropriate data to answer the research question. In addition to examining the cases by the eight constitutionally protected rights, the researcher used both the teacher-as-role-model and nexus theories as a means to understand the cases. These results allowed the researcher to answer the research question: When is it legal for P-12 public school employers to discipline employees for off-duty conduct? 


\section{CHAPTER V \\ DISCUSSION, IMPLICATIONS, AND CONCLUSIONS}

Introduction

The purpose of the study was to identify the legal contours of judicial responses to challenges related to adverse employment actions against $\mathrm{P}-12$ public school employees for off-duty conduct. Through a critical examination of the relevant case law, the researcher identified and studied the legal rights courts utilized to analyze and decide the off-duty conduct cases. A full understanding of the specific legal rights courts employed allowed the researcher to answer the research question: When is it legal for P-12 public school employers to discipline employees for off-duty conduct?

\section{Discussion}

Courts grant wide latitude to $\mathrm{P}-12$ public school employers to discipline employees for off-duty conduct. Employers prevailed in $57 \%$ of the one hundred and sixty-one identified cases. Furthermore, courts often presume the correctness of employer actions. While public school employers possess the authority to discipline an employee for conduct occurring away from the schoolhouse, employees possess some constitutional protections. The research indicated that employees relied on eight constitutional arguments when contesting adverse employment decisions based on off-duty conduct.

Employees asserted the right to privacy when challenging adverse employment decisions. The researcher identified fifteen cases where courts ruled whether an employee's off-duty conduct enjoyed constitutional protection under the right to privacy. 
The results of these fifteen cases draw a distinct line between conduct that is private and conduct that is public. Several cases turned to the U.S. Supreme Court's description of "zones of privacy"1 indicating that there are certain areas in which government does not possess the right to intrude. Conduct related to procreation usually enjoys privacy protection. Sexual activity also enjoys privacy, until the sexual activity occurs in a public place, or in such a way that others may view the activity. Morrison, when he engaged in a private, consensual homosexual encounter, prevailed on his claim to privacy. On the other hand, Pettit, Wishart, and Ross did not prevail because of the public nature of their sexual activity. Additionally, other types of conduct enjoy privacy, such as marital activities, unless the conduct is public. When off-duty conduct takes on a public nature, courts do not always afford protection to the conduct under the right to privacy. In these instances, employers may legally discipline an employee for off-duty conduct.

Courts resolved seven cases on the constitutional right to freedom of association. Employers prevailed in three of the cases, although the courts did not deny that the employees possessed the right to associate freely. While employees hold the right to associate freely with any organization, the right does not always protect an employee from adverse action. When employers can show imminent harm or potential disruption stemming from an employee's associational activities, courts find those concerns persuasive. Employers may legally discipline an employee for their off-duty conduct in those instances.

Where off-duty conduct included expressive association, employees prevailed when bringing suit against their employer. In these cases, employees' associational activities did not possess the potential to cause harm or disruption to the school. Therefore,

\footnotetext{
${ }^{1}$ See Griswold v. Connecticut, 381 U.S. 479 (1965).
} 
employers legally could not discipline in those instances. Furthermore, the courts found for employees in two cases involving intimate associational activity. Courts afford protection to employee conduct involving an intimate association, such as marriage, and employers cannot use the association as a basis for discipline.

The researcher identified sixteen cases involving judicial considerations of employee claims of freedom of speech. Expressive activity enjoys constitutional protection in many instances. Employers may not discipline an employee for the exercise of pure speech, as in the case of National Gay Task Force. ${ }^{2}$ The court found that mere advocacy or promotion of an idea did not necessarily lead to disruption in the school setting. Therefore, the employer's restriction on expressive activity that advocated gay rights was not a legal restriction.

Employees deserve protection for speech involving a matter of public concern. Courts clearly articulated this idea in Thompson v. Board of Education ${ }^{3}$ and Hall v. Marion School District. ${ }^{4}$ In both cases, employees received discipline after making negative comments about their respective school districts. The court found their expressive activity protected as both spoke on issues of public concern. If an employee's speech does not involve an issue of public concern, an employer has much greater latitude to discipline the employee for that speech. For instance, Rowland's speech related to her homosexual lifestyle did not involve a matter of public concern. ${ }^{5}$

\footnotetext{
${ }^{2} 729$ F.2d 1270 (10th Cir. 1984).

${ }^{3} 711$ F.Supp. 394 (N.D. III. 1989).

${ }^{4} 31$ F.3d 183 (4th Cir. 1994).

${ }^{5}$ Rowland v. Mad River Local Sch. Dist., 730 F.2d 444 (6th Cir. 1984).
} 
Sometimes an employee's speech involving a matter of public concern becomes the basis for discipline when the speech causes disruption to the life and work of the school. ${ }^{6}$ The courts, though, relied on Tinker $^{7}$ to assess whether employee speech caused a "material or substantial disruption" to the life of the school. Where there is no evidence of speech causing a material or substantial disruption, courts view employer discipline based on speech as illegal.

Only one court addressed the right to freedom of religion when making a decision related to an employee's off-duty conduct. This did not provide enough data to draw any conclusion on how this constitutional right could protect an employee from an adverse employment decision.

Only six cases involved courts considering a right to reputation claim. Of the six cases, employers prevailed in four instances. Courts found that employers' adverse decision did not deprive a right to reputation when the damage occurred after job loss. Additionally, a claim of right to reputation failed when the employee never refutes the charges of misconduct. Finally, if employees' own actions cause harm to their reputation, courts do not find a deprivation of right to reputation occurs. In these cases, courts found employee disciplinary actions legal. On the other hand, courts find that employers act illegally when harm to an employee's reputation occurs during the course of discipline.

Courts considered procedural due process claims in fifty-three of the cases. The researcher specifically considered procedural due process claims where employees argued deprivation of due process because employers failed to provide "notice of the rules." Courts require employers to provide clear and unambiguous rules to employees so

\footnotetext{
${ }^{6} 336$ F.3d 185 (2nd Cir. 2003).

${ }^{7}$ See Tinker v. Des Moines Indep. Cmty. Sch. Dist., 393 U.S. 503 (1969).
} 
that employees know what is expected of their off-duty conduct. When courts assume a reasonable person would know what conduct employers proscribe, an employee deprivation claim of procedural due process fails. When rules remain vague or do not exist, employee challenges survive on deprivation of the right to procedural due process.

Turning to the right of substantive due process, the researcher found this legal right emerged in more cases than any other legal right examined. Sixty-nine courts decided cases on this issue. The right to substantive due process directly deals with employer actions and whether those actions involve fairness and reason. While employers prevailed in the majority of these cases, courts demanded that employees receive fair and reasonable treatment.

Sixteen cases turned on the legal right of equal protection. The initial court consideration in equal protection cases revolves around whether or not government action caused discrimination. Without discriminatory intent, an equal protection claim fails to arise. When government discriminated in these employee discipline situations, courts found the discrimination did not violate an employee's right to equal protection in nine instances. The courts found the employers' actions legal with certain exceptions. Employer actions must equally affect similarly situated persons. The case of Shelton $v$. Richmond Public Schools ${ }^{8}$ provides a clear example of what the judiciary means by equal treatment. All employees, not just Shelton, possessing felony convictions faced disciplinary action by their employer. On the other hand, the case of Allen v. Board of Education ${ }^{9}$ provides an example of when employer discrimination involved unequal

\footnotetext{
${ }^{8} 186$ F.Supp.2d (E.D. Va. 2002).

${ }^{9} 584$ S.W.2d 408 (Ky. Ct. App. 1979).
} 
treatment. In this instance, employees involved in other types of off-duty conduct were not subject to the same treatment and regulations as the employees in Allen.

The second exception requires government to possess a compelling interest for the discrimination when the government action burdens a suspect class or fundamental right. If the discrimination does not burden a suspect class or fundamental right, the employer must then possess only a rational basis for the discrimination. For instance, the employer in Grossman ${ }^{10}$ believed that Grossman's continued presence in the classroom caused the potential for harm. The court's assessment of the facts agreed with the employer. On the other hand, Weaver v. Nebo School District ${ }^{11}$ clearly shows when the courts find an employer possess no rational basis for the discrimination caused by the discipline action. Courts demand that employers treat similarly situated employees in an equal manner, and that employer discipline decisions involve, at the very least, a rational basis.

The nature of the study afforded the researcher the opportunity to assess more than the legal rights framing the judicial response to the research question. The data collected reflected an ongoing trend by the courts to refer to both the role model and nexus theories when considering legal challenges for off-duty conduct. While courts in the 1970's, 1980 's and 1990's turned to the nexus theory more than the role model theory, the cases identified from the current decade indicate an even use of the theories by the courts. One hundred and forty-five, or $90 \%$, of the cases identified indicated a court consideration of one or both theories. While courts do not base their outcomes directly on either theory, the use of the theories remains a significant finding from the research.

\footnotetext{
${ }^{10}$ In re Grossman, 316 A.2d 39 (N.J. App. Div. 1974).

${ }^{11} 29$ F.Supp.2d 1279 (D. Utah 1998).
} 
Turning to the role model theory, the ongoing consideration by courts through each decade is reflective of the literature review findings. The literature review indicated that since antiquity, society has held teachers to a higher standard than most other persons and professionals. An ever present expectation exists that public school employees will live their life according to a certain moral standard, on and off the clock. This belief exists because teachers are role models for something much more than intellectual wisdom. Teachers model values and influence students through their conduct. This is why employers and society hold great concern for how a teacher lives away from school. The research indicates that courts also possess a great concern for how public school employees conduct themselves off-duty. Courts affirmed in sixty-six of the identified cases that teachers are indeed role models.

But courts also subscribed to the nexus theory beginning in the late 1960 's as a way to balance the role model criteria. The establishment of a nexus between teachers' offduty conduct and their employment position affords courts the ability to consider employee claims in a more objective manner. Courts often ask if a rational connection exists between the job and the off-duty conduct.

The data collection form allowed for the collection of data providing the researcher with the means to assess relationships among the cases. The study identified one hundred and sixty-one cases and employers prevailed in $57 \%$ of all cases. That number significantly increased when the off-duty conduct involved criminal behavior. In those cases, courts upheld employer discipline $70 \%$ of the time. On the other hand, when employee conduct involved non-criminal activity, courts found for the employee in $65 \%$ of the cases. It remains significant to note that two thirds of the identified cases involved 
criminal conduct on the part of the employee. Employers are more apt to discipline an employee for off-duty conduct that involves criminal activity than for non-criminal conduct.

The researcher coded thirteen types of employee off-duty conduct on the data analysis form. Employees received discipline for drug use more so than for any other type of conduct. The off-duty conduct in $21 \%$ of the cases involved drug use. The broad category of "other" criminal conduct made up the next largest grouping of disciplined employees with $16 \%$ of the cases. The data indicated that off-duty conduct involving fraudulent behavior showed up the least among the thirteen types of identified conduct. Additionally, employers prevailed in all cases involving fraudulent behavior on the part of an employee. The reverse occurred with regard to out-of-wedlock pregnancy. No employer prevailed when discipline occurred on the basis of an unmarried employee becoming pregnant.

In terms of employee demographics, the data revealed a less than detailed picture. Male employees made up two thirds of the employees in the cases. The overwhelming majority of the employees held teaching positions, but that would seem obvious considering the makeup of the P-12 public school employment workforce. Thirty-eight percent of the cases did not reveal tenure status of the employee while less than one percent indicated the race of the employee. No case identified whether an employee held union membership.

In terms of the school level in which the employee worked, high school employees made up the largest group with the cases reporting forty-one high school employees. This number, though, remains unreliable, as $40 \%$ of the cases failed to indicate school level. 
An examination of off-duty conduct by school level indicated that elementary school employees engaged in all identified types of conduct, whereas middle school employees were involved in the least number of types of conduct. Again, the sixty-eight cases where school level remains unidentified make these findings less than dependable.

The researcher clustered the categories for employee loss into two sub-categories representing maximum loss and minimum loss. The researcher considered a loss as maximum, if the discipline left the employee without a position. Overwhelmingly, employees bringing suit against employers for discipline of off-duty conduct faced a maximum loss. Eighty-three of the cases involved maximum losses. In these cases, employees prevailed three out of five times. When the loss was minimal, employers prevailed just less than half of the time.

Both federal and state courts considered the identified cases. Seventy-five percent of the cases received more than one judicial hearing. In the instances where employees only faced one hearing level, they prevailed $60 \%$ of the time. This percentage reversed, though, regarding cases that received multiple hearings. Cases with multiple hearings often provided judicial support for disciplining of employees for off-duty conduct. In those instances, employers prevailed $60 \%$ of the time at the final hearing level. In the cases receiving multiple hearings, employers also prevailed at a visibly higher rate than employees at the first hearing level. Perhaps this trend indicates that employers who do not prevail at a level one hearing remain less likely to appeal the decision to a higher court than an employee who does not prevail at level one; whereas an employee remains more likely to pursue an appeal after losing the first judicial hearing. 


\section{Implications for Practice}

The research findings provide several noteworthy implications for practice relevant for both employers and employees. Employers must remember that employees do enjoy some constitutional protections in the workplace. Employers must pay particular attention to the due process rights of employees. During the course of any discipline proceeding, offering basic procedural requirements remains necessary, including notice and hearing. It remains critically important to inform employees of any expectations regarding offduty conduct prior to disciplining an employee. Employers also must ensure their discipline processes meet minimal standards of fairness and reasonableness to avoid a successful challenge on substantive due process grounds.

The research also sends a clear message to employers that equal treatment remains a clear expectation of the courts. When employers mete out discipline for off-duty conduct unevenly among similarly situated employees, that discipline fails to pass judicial review. Employers must also possess at least a rational basis for disciplining an employee for offduty conduct.

In terms of the privacy rights and expressive activities, employers must indicate that the activity somehow disrupts the life of the school in order to discipline an employee. It is not enough to find the off-duty distasteful or immoral.

Overall, employers fare better in the judicial system than employees, at least on the issue of disciplining an employee for off-duty conduct. In particular, employers remain more likely than employees to prevail in a case with multiple hearings. This finding may encourage employers to pursue an appeal when a lower court overturns their adverse employment decision. Employees can take heed from this finding that their employers 
may discipline them for off-duty conduct and courts will find that discipline action legal more often than not.

The research clearly indicates drug use and other criminal conduct as the types of off-duty conduct causing the highest number of adverse employment decisions. This information can also be a warning to an employee that this type of conduct may indeed jeopardize their job.

\section{Implications for Future Research}

Several research objectives emerge from the findings of this study. In relation to the data, one could further examine the high number of cases in California and Pennsylvania. The high number of cases emerging from these states lends to an assortment of questions that further study could address.

The cases identified in the research only came from the national reporting system. It is likely there are many judicial outcomes regarding off-duty conduct of public school personnel that go unreported. Furthermore, it would be informative to see how many adverse employment decisions based on off-duty conduct never see the inside of a court room. How often do employers discipline for off-duty conduct with no employee challenge to the decision?

As with any study, it would be helpful to track this same data in the years to come. For instance, when this decade ends, how many more cases will emerge involving offduty conduct of public school employers? Will courts continue to depend upon the role model and nexus theories as they consider the legal challenges employees make when suing their employer? Also, what types of off-duty conduct will future cases involve? It behooves employers to know for what conduct employees may possess a propensity and 
employees need to know what conduct potentially jeopardizes employment in public schools.

This research limited inquiry to the P-12 public school arena. Does this issue of offduty conduct emerge in the public higher education setting? Are university and college employees held to the same standards as a P-12 school employee? What happens to the role model theory in a higher education setting?

A final thought regarding future research involves a question regarding notice that employees receive in regard to off-duty conduct. The researcher speculated how employees receive this "notice of the rules." For instance, do employers ever share information about off-duty conduct expectations during an interview and selection process with a prospective employee? Or do employers wait for the inevitable employee orientation to share the expectations regarding off-duty conduct? Maybe employees found out the "rules of the game" during their educational requirements prior to even applying for a teaching job. Do teacher-training programs let future teachers know what employers expect of them in terms of their off-duty conduct?

\section{Conclusions}

Courts grant extensive autonomy to $\mathrm{P}-12$ public school employers to discipline employees for off-duty conduct. Additionally, the research indicates that courts mirror the larger society in their expectation that teacher conduct maintains a certain moral standard on and off the clock. Employees, though, do enjoy some constitutional protections for their off-duty conduct, particularly conduct that does not involve criminal activity. Employees must realize that their conduct remains ever subject to the scrutiny of the employer. 


\section{REFERENCES}

Books

Alexander, K. \& Alexander, M. D. (1992). American public school law. St. Paul, MN: West Publishing Company.

Allen, M. K. (1990). Legal aspects of teacher dismissal for immorality on grounds of sexual misconduct. Unpublished doctoral dissertation, University of North Carolina, Greensboro.

Andersen, (1939). Trends in causes of teacher dismissal as shown by American court decisions. Unpublished doctoral dissertation, George Peabody College for Teachers, Nashville, TN.

Avent, J. E. (1931). The excellent teacher. Knoxville: University of TN Press.

Bandura, A. (1971). Psychological modeling. Chicago: Aldine-Atherton.

Bandura, A. (1977). Social learning theory. Englewood Cliffs, NJ: Prentice Hall.

Bartlett, J. (1992). Familiar quotations. Boston: Little Brown and Company.

Beale, H. K. (1936). Are American teachers free? New York: Charles Scribners Sons.

Beale, H. K. (1941). A history of freedom of teaching in American schools. New York: Charles Scribners Sons.

Bennett, W. (1993). The book of virtues. New York: Simon \& Schuster.

Benway, M. P. (1976). An analysis of higher court cases relating to the dismissal, suspension, and discipline of public school teachers on the ground of immorality. Unpublished doctoral dissertation, Indiana State University, Ft. Wayne.

Black's law dictionary (7th ed.). (1999). St. Paul, MN: West Group.

Bode, B. H. (1928). Fundamentals of education. New York: Macmillan Company.

Bower, W. C. (1952). Moral and spiritual values in education. Lexington: University of KY Press. 
Chemerinsky, E. (1997). Constitutional law principles and policies. New York: Aspen Law and Business.

Clark, C. M. (1990). The teacher and the taught: Moral transactions in the classroom. In J. I. Goodlad (Ed.), The moral dimensions of teaching. San Francisco: JosseyBass.

Cohen, M. L. \& Olson, K. C. (1996). Legal research in a nutshell. St. Paul, MN: West Group.

Corpus Juris Secundum Constitutional Law § 502, 16A.

Corpus Juris Secundum Constitutional Law § 544, 16B.

Dahl, J. A., Laser, M., Cathcart, R. \& Marcus, F. (1964). Student, school and society. San Francisco: Chandler Publishing.

Dearden, R., Hirst, P. \& Peters, R. (1975). Education and the development of reason. London: Routledge.

Dewey, J. (1909). Moral principles in education. Boston: Houghton Mifflin.

Dewey, J. (1916). Democracy and education. New York: Macmillan Company.

Donovan, F. R. (1938). The schoolma'am. New York: Frederick A. Stockes Company.

Elias, J. L. (1995). Philosophy of education: Classical and contemporary. Malabar, FL: Krieger Publishing Company.

Elsbree, W. S. (1939). The American teacher: Evolution of a profession in a democracy. New York: American Book Company.

Fernstermacher, G. D. (1990). Some moral considerations on teaching as a profession. In J. L. Goodlad (Ed.), The moral dimensions of teaching (pp. 130-151). San Francisco: Jossey-Bass.

Fisher, L. \& Schimmel, D. (1981). Teachers and the law. New York: Longman, Inc.

Garner, B. A. (2002). The Redbook: A manual on legal style. St. Paul, MN: West Group.

Goodlad, J. I. (1984). A place called school. New York: McGraw-Hill Book Company.

Goodlad, J. I., Soder, R. \& Sirotnik, K. (1990). The moral dimensions of teaching. San Francisco: Jossey-Bass. 
Harbeck,K. M. (1987). Personal freedoms/public constraints: An analysis of the controversy over the employment of homosexuals as schoolteachers. Unpublished doctoral dissertation, Stanford University.

Hartford, E. (1958). Moral values in public education: Lessons from the Kentucky experiment. New York: Harper and Brothers.

Hill, M. F. \& Wright, J. A. (1993). Employee lifestyle and off-duty conduct regulation. Washington, D.C.: The Bureau of National Affairs, Inc.

Hobson, E. G. (1918). Educational legislation and administration in the State of New York From 177 to 1850. Chicago: University of Chicago Press.

Jackson, P. W. (1986). The practice of teaching. New York: Teachers College Press.

Joseph, P. B. (2001). The ideal teacher: Images in early $20^{\text {th }}$ century teacher education textbooks. In P. B. Joseph \& G. E. Burnaford (Eds.), Images of schoolteachers in America. Mahwah, NJ: Lawrence Erlbaum Associates.

Kaufman, P. W. (1984). Women teachers on the frontier. New Haven: Yale University Press.

Kohlberg, L. (1971). Stages of moral development as a basis for moral education. In C. M. Beck, et al., Moral education: Interdisciplinary approaches. Toronto: University of Toronto Press.

Kounin, J. S. (1970). Discipline and group management in classrooms. New York: Holt, Rinehart and Winston.

Kulp, D. (1932). Educational sociology. New York: Longmans Inc.

LaMorte, M. W. (1993). School law: Cases and concepts. Boston, MA: Allyn \& Bacon.

Levy, L. W. \& Karts, K. L. (Eds.) (2000). Encyclopedia of the American Constitution. New York: Macmillan Reference.

Lewis, E. E. (1925). Personnel problems of the teaching staff. New York: The Century Company.

Lewis, T. T. (2002). The Bill of Rights. Pasadena, CA: Salem Press, Inc.

Lieberman, M. (1956). Education as a profession. Englewood Cliffs, NJ: Prentice Hall.

Mitchell, C. T. (1989). Values in teaching and professional ethics. Macon, GA: Mercer University Press. 
Morgan, J. (1986). Godly learning: Puritan attitudes toward reason, learning, and education. Cambridge: University Press.

Morgan, M. L. (1990). Platonic piety: Philosophy and ritual in fourth-century Athens. New Haven: Yale University Press.

Mullins, L. G. (1995). Dismissal of teachers for out-of-school sexual immorality not involving students: Limitations and guidelines regarding the privacy rights of teachers. Unpublished doctoral dissertation, Ohio State University, Columbus.

National Commission on Teacher Education and Professional Standards (1964). Invitation to teaching. Washington D.C.: Washington.

Noddings, N. (1984). Caring: A feminine approach to ethics and moral education. Berkley: University of CA Press.

Pearsall, J. \& Trumble, B. (Eds.). (1996). Oxford English dictionary. Oxford: Oxford University Press.

Perrone, V. (1991). A letter to teachers: Reflections on schooling and the art of teaching. San Francisco: Jossey-Bass.

Piaget, J. (1965). The moral judgment of the child. New York: Free Press.

Pullias, E. V. \& Young, J. D. (1968). A teacher is many things. Bloomington, IN: Indiana University Press.

Reutter Jr., E. E., \& Hamilton, R. R. (1985). The law of public education. Mineola, NY: Foundation press.

Rollins, S. P., \& Unruh, A. (1964). Introduction to secondary education. Chicago: Rand McNally \& Company.

Rouse, W. H. D. (1956). Great dialogues of Plato. New York: New American Library.

Russo, C. J. (1996). Legal research: The "traditional" method. In D. Schimmel (Ed.), Research that makes a difference: Complimentary methods for examining legal issues in education. Topeka, KS: National Organization on Legal Problems of Education.

Sizer, T. R. \& Sizer, N. F. (1999). The students are watching. Boston: Beacon Press.

Spring, J. J. (1985). American education: An introduction to social and political aspects. New York: Longman Inc. 
Stephenson, J., Ling, L., Burman, E. \& Cooper, M. (1998). Values in education. London: Routledge.

Taylor, L., McMahill, D. \& Taylor, B. (1960). The American secondary school. New York: Appleton-Century-Crofts, Inc.

The Bluebook: A uniform system of citation (17th ed.). (2000). Cambridge, MA: Harvard Law Review Association.

Thomas, R. M. (1985). Comparing theories of child development (2nd ed.). Belmont, CA: Wadsworth Publishing Company.

Tom, A. R. (1984). Teaching as a moral craft. New York: Longman Inc.

Urmson, J. O. (1988). Aristotle's ethics. Oxford: Basil Blackwell Ltd.

Valente, W. D. (1987). Law in the schools. Columbus, OH: Merrill Publishing Company.

Vile, J. R. (1996). Encyclopedia of constitutional amendments. New York: Macmillan Reference.

Weigart, K. M. (1999). Moral dimensions of peace studies. In American Association of Higher Education (Ed.), Teaching for justice. Washington D.C: American Association for Higher Education.

West's encyclopedia of American law. (1998). St. Paul, MN: West Group.

Wilson, J. Q. (1993). The moral sense. New York: Free Press.

Woodring, P. (1957). A fourth of a nation. New York: McGraw-Hill Book Company.

Wright, H.P. (1920). The young man and teaching. New York: Macmillan Company.

Yolton, J. W. (1971). John Locke and education. New York: Random House.

Articles

Adams, M. (1995, September). Private lives. Sales \& Marketing Management, 40-47.

Alaniz, R. (1990, August). Off-duty conduct: Make it a company policy. Electric Light Power, 58-68.

Alonso, M. (1990, April). When an employee has personal problems. Supervisory Management, 1-3.

Belkin, G. S. (1972). The teacher as hero. Educational Theory, 22(4), 411-419. 
Bergem, T. (1990). The teacher as moral agent. Journal of Moral Education, 19(2), 88100.

Blase, J. J. (1983). Teachers' perceptions of moral guidance. Clearinghouse Review, 56(9), 389-393.

Bolmeier, E. C. (1960). Legal scope of teachers' freedoms. Educational Forum, (24)199206.

Bullock \& Faber, (1989). The right of privacy of public school employees. (ERIC Reproduction Services No. ED303861), 1-28.

Butroyd, B. (1997). Are the values of secondary school teachers really in decline? Education Review, 49(3), 251-258.

Buzzelli, C. \& Johnston, B. (2001). Authority, power, and morality in education. Teaching and Teacher Education, 17, 873-874

Calloway, B. (1951). Are teachers under community pressure? School and Community, $37,458-459$.

Cozzetto, D. A. \& Pedeliski, T. B. (1997). Privacy and the workplace. Public Personnel Management, 26(4), 515-528.

Davis, (1972). Teacher dismissal on grounds of immorality. Clearing House, 46, 418423.

Day, C. \& Leitch, R, (2001). Teachers' and teacher educators' lives: The role of emotion. Teaching \& Teacher Education, 17, 403-415.

Delon, F. G. (1985). A teacher's sexual involvement with pupils: "Reasonable cause" for dismissal. Education Law Reporter, 22, 1085-1093.

DeMitchell, T. A. (1993). Private lives: Community control v. professional autonomy. Education Law Reporter, 78, 187-197.

Dworkin, T. M. (1997). It's my life - leave me alone: Off the job employee associational privacy rights. American Business Law Journal 35, 47-101.

Fallona, C. (2000). Manner in teaching: A study in observing and interpreting teachers' moral virtues. Teaching \& Teacher Education, 16, 681-695.

Fereshteh, H. (1996). The nature of teaching, effective instruction, and roles to play: A social foundations perspective. Contemporary Education, 73-75. 
Flinders, N. J. (1991). Values, morality, and religion in the school. (ERIC Document Reproduction Service No. ED356988), 1-18.

Hansen, D. T. (1993). From role to person: The moral layeredness of classroom teaching. American Educational Research Journal, 30(4) 651-674.

Hargreaves, A. (1996). Development and desire: A postmodern perspective. (ERIC Document Reproduction Service No. ED 372057).

Hooker, C. P. (1994). Terminating teachers and revoking their licensure for conduct beyond the schoolhouse gate. Education Law Reporter, 96, 2-15.

Imber, M. (2001, April). Morality and teacher effectiveness. American School Board Journal, 64-66.

Johnston, B., Juhasz, A., Marken, J. \& Ruiz, B. (1998). The ESL teacher as moral agent, Research in Teaching English, 32(2), 161-181.

Joseph, P. B. \& Efron, S. (1993). Moral choices/moral conflicts: Teachers' selfperceptions. Journal of Moral Education, 22(3), 201-220.

Kearney, R. A. (1993). Arbitral practice and purpose in employee off-duty misconduct cases. Notre Dame Law Review, 69(1), 135-156.

Kennedy, M. M. (1989). Policy issues in teacher education. (ERIC Reproduction Services No. ED326538) 21-24.

Koenig, R. A. (1968, January). Teacher immorality and misconduct. American School Board Journal, 15-19.

Leap, T. L. (1988). When can you fire for off-duty conduct? Harvard Business Review 66, 28-36.

Lehman, W. \& Simpson, D. D. (1992). Employee substance use and on-the-job behaviors. Journal of Applied Psychology, 77(3) 309-321.

Levine, M. J. (1985). Regulating the off-duty conduct of public employees:

Constitutional issues. Journal of Collective Negotiations 14(4), 359-373.

Linowes, D. F. \& Spencer, R. C. (1990). Privacy: The workplace issue. Journal Marshall Law Review, 23, 591-624.

MacNeil, B. M. (2000). Disciplining the off-duty teacher. Education Canada, 36-37.

Mantel, D. L. (1999, October). Off-duty doesn't mean off the hook. $R N, 71-73$. 
Marmo, M. (1985). Public employees: On-the-job discipline for off-the-job behavior. Arbitration Journal, 3-10.

Miller, J. L. et al. (1993). Employer restrictions on employees' legal off-duty conduct. Labor Law Journal, 44, 208-219.

Miller, N. (1990). Criminal convictions, "off-duty" misconduct, and federal employment: The need for better definition of the basis for disciplinary action. American University Law Review 39, 869-913.

Miller, P. (1975). Who are the moral experts? Journal of Moral Education, 5(1), 3-12.

Nolte, M. C. (1967). Teacher's image, conduct important. American School Board Journal, 27-29.

Nolte, M. C. (1987). Establishing the nexus: A school board primer. Education Law Reporter 38, 1-13.

On the role of teacher. (1967). (ERIC Reproduction Services No. ED022729) 1-21.

Pinchbeck, I, (1956). The state and the child in sixteenth century England. British Journal of Sociology, 7, 273-285.

Prosser, W. L. (1960). Privacy. California Law Review, 48, 383-423.

Punke, H. H. (1965). Immorality as a grounds for teacher dismissal. NASSP Bulletin, 53-69.

Putman, D. (1995). The primacy of virtue in children's moral development. Journal of Moral Education, 24(2), 175-182.

Silbergeld, A. F. \& Sasaki, S. T. (2000). The right to regulate off-duty conduct. Employment Relations Today, 27(2), 101-108.

Smith, W. (1966). The teacher in Puritan culture. Harvard Education Review, 36, 394411.

Tisak, M. S. et al. (2000). Young children's conceptions of authority in context. MerrillPalmer Quarterly, 46(1), 168-187.

Trebilcock, J. (2000). Off campus: School board control over teacher conduct. Tulsa Law Journal, 35, 445-465.

Vaskov,S. G. (1985). Judicial review of dismissal of civil service employees for off-duty misconduct: The approach of the federal circuit. American University Law Review, 34, 439-478. 
Walden, (1974). A right to privacy. National Elementary Principal, 86-88.

Warren, S. D. \& Brandeis, L. D. (1890). The right to privacy. Harvard Law Review, 4, 193-220.

Webster, G. D. (1992, July). Regulating employees' off-duty conduct. Association Management, 99-102.

Wilcots, R. L. (1995, January). Employee discipline for off-duty conduct: Constitutional challenges and the public policy exception. Labor Law Journal, 46, 3-16.

\section{Case Law}

Adams v. State of Florida, Professional Practices Council, 406 So. 2d 1170 (Fla. Dist. Ct. App. 1981).

Adkins v. West Virginia Department of Education, 556 S.E.2d 72 (W. Va. 2001).

Alabama Education Association v. Wallace, 362 F.Supp. 682 (M.D. Ala. 1973).

Alford v. Ingram, 931 F.Supp. 768 (M.D. Ala. 1996).

Allen v. Board of Education, 584 S.W.2d 408 (Ky. Ct. App. 1979).

Ambus v. Granite Board of Education, 975 F.2d 1555 (10th Cir. 1992).

Andrews v. Drew Municipal Separate School District, 371 F.Supp. 27 (N.D. Miss. 1973).

Andrews v. Independent School District No. 57, 12 P.3d 491 (Okla. Ct. App. 2000).

Appeal of Batrus, 26 A.2d 121 (Pa. Super. Ct. 1942).

Avery v. Homewood City Board of Education, 674 F.2d 337 (5th Cir. 1982).

Baird v. School District, 287 P. 308 (Wyo. 1930).

Baker v. School Board, 450 So. 2d 1194 (Fla. Dist. Ct. App. 1984).

Baker v. School District, 371 A.2d 1028 (Pa. Commw. Ct. 1977).

Baltrip v. Norris, 23 S.W.3d 336 (Tenn. Ct. App.2000).

Barcheski v. Board of Education, 412 N.W.2d 296 (Mich. Ct. App. 1987).

Barringer v. Caldwell County Board of Education, 473 N.E.2d 435 (N.C. Ct. App. 1996). 
Bates v. State Bar of Arizona, 433 U.S. 350 (1977).

Bertrand v. New Mexico State Board of Education, 544 P.2d 1176 (N.M. Ct. App. 1976).

Board of Directors v. Davies, 489 N.W.2d 19 (Iowa 1992).

Board of Education v. Adelman, 423 N.E.2d 254 (Ill. App. Ct. 1981).

Board of Education v. Calderon, 110 Cal. Rptr. 916 (Cal. Ct. App. 1974).

Board of Education v. Jack M., 566 P.2d 602 (Cal. 1977).

Board of Education v. Wilkinson, 270 P.2d 82 (Cal. Dist. Ct. App. 1954).

Board of Public Education School District v. Intille, 163 A.2d 420 (Pa. 1960).

Board of Regents v. Roth, 408 U.S. 564 (1972).

Board of Trustees v. Judge, 123 Cal. Rptr. 830 (Cal. Dist. Ct. App. 1975).

Bogart v. Unified School District, 432 F.Supp. 895 (D. Kan. 1977).

Bowalick v. Commonwealth, 840 A.2d 519 (Pa. Commw. Ct. 2004).

Brown v. Bathke, 566 F.2d 588 (8th Cir. 1977).

Brownsville Area School District v. Alberts, 260 A.2d 765 (Pa. 1970).

Burton v. Cascade School District, 512 F.2d. 850 (9th Cir. 1975).

C.F.S. v. Mahan, 934 S.W.2d 615 (Mo. Ct. App. 1996).

Califano v. Webster, 430 U.S. 313 (1977).

Cameron v. Board of Education, 795 F.Supp. 228 (S.D. Ohio 1991).

Central Hudson Gas \& Electric Corporation v. Public, 447 U.S. 557 (1980).

Chicago Board of Education v. Payne, 430 N.E.2d 310 (Ill. App. Ct. 1981).

City of Knoxville Board of Education v. Markelonis, 460 S.W.2d 362 (Tenn. Ct. App. 1970).

Clark v. Ann Arbor School District, 344 N.W.2d 48 (Mich. Ct. App. 1983). 
Clark v. School Board, 596 So. 2 d 735 (Fla. Dist. Ct. App. 1992).

Coleman v. Reed, 147 F.3d 751 (8th Cir. 1998).

Comings v. State Board of Education, 100 Cal. Rptr. 73 (Cal. Ct. App. 1972).

Connick v. Myers, 461 U.S. 138 (1983).

Conway v. Hampshire County Board of Education, 352 S.E.2d 739 (W. Va. 1986).

Crumpler v. State Board of Education, 594 N.E.2d 1071 (Ohio Ct. App. 1991).

Dennis v. S \& S Consolidated Rural High School District, 577 F.2d 338 (5th Cir. 1978).

Denton v. South Kitsap School District, 516 P.2d 1080 (Wash. Ct. App. 1973).

Deshields v. Chester Upland School District, 505 A.2d 1080 (Pa. Commw. Ct. 1986).

Di Genova v. State Board of Education, 288 P.2d 862 (Cal. 1955).

Dominy v. Mays, 257 S.E.2d 317 (Ga. Ct. App. 1979).

Drake v. Covington County Board of Education, 371 F.Supp. 974 (M.D. Ala. 1974).

Dupree v. School Committee of Boston, 446 N.E.2d 1099 (Mass. App. Ct. 1983).

Eckmann v. Board of Education, 636 F.Supp. 1214 (N.D. Ill. 1986).

Eisenstatdt v. Baird, 405 U.S. 113 (1972).

Ellis v. Ambach, 508 N.Y.S.2d 624 (N.Y. App. Div. 1986).

Employment Division v. Smith, 494 U.S. 872 (1990).

Erb v. Iowa State Board of Public Instruction, 216 N.W.2d 339 (Iowa 1974).

Ex Parte Alabama State Tenure Commission v. Lee County Board of Education, 595 So. 2d 479 (Ala. 1991).

Faxon v. School Committee, 120 N.E.2d 772 (Mass. 1954).

Feagin v. Everett, 652 S.W.2d 839 (Ark Ct. App. 1983).

Fielder v. Board of Directors, 662 N.W.2d 371 (Iowa Ct. App. 2003).

Fischler v. Askew, 349 So. 2d 227 (Fla. Dist. Ct. App. 1977). 
Fisher v. Snyder, 476 F.2d 375 (8th Cir. 1973).

Ford v. Bay County School Board, 246 So. 2d 119 (Fla. Dist. Ct. App. 1970).

Fountain v. State Board of Education, 320 P.2d 899 (Cal. Dist. Ct. App. 1958).

Freeman v. Town of Bourne, 49 N.E. 435 (Mass. 1898).

Garcia v. State Board of Education, 694 P.2d 1371 (N.M. Ct. App. 1984).

Gaylord v. Tacoma School District, 559 P.2d 1340 (Wash. 1977).

Gedney v. Board of Education, 703 A.2d 804 (Conn. App. Ct. 1997).

Gish v. Board of Education, 366 A.2d 1337 (N.J. 1976).

Glover v. Williamsburg Local School District, 20 F.Supp.2d 1160 (S.D. Ohio 1998).

Golden v. Board of Education, 285 S.E.2d 665 (W. Va. 1982).

Gosney v. Sonora Independent School District, 603 F.2d 522 (5th Cir. 1979).

Gover v. Stovall, 35 S.W.2d 24 (Ky. 1931).

Governing Board v. Brennan, 95 Cal. Rptr. 712 (Cal. Ct. App. 1971).

Governing Board v. Mann, 588 P.2d 1 (Cal. 1977).

Griswold v. Connecticut, 381 U.S. 479 (1965).

Hainline v. Bond, 824 P.2d 959 (Kan. 1992).

Hale v. Board of Education, 234 N.E.2d 583 (Ohio 1968).

Hall v. Marion School District, 31 F.3d 183 (4th Cir. 1994).

Hamm v. Poplar Bluff R-1 School District, 955 S.W.2d 27 (Mo. Ct. App. 1997).

Hamm v. Poplar Bluff School District, 955 S.W.2d 27 (Mo. Ct. App. 1997).

Hankla v. Governing Board, 120 Cal. Rptr. 827 (Cal. Ct. App. 1975).

Harmon v. Mifflin County School District, 713 A.2d 620 (Pa. 1998).

Hines v. Board of Education, 492 F.Supp 469 (E.D. Ky. 1980). 
Hoagland v. Mount Vernon School District, 623 P.2d 1156 (Wash. 1981).

Hoffman v. State Board of Education, 763 N.E.2d 210 (Ohio Ct. App. 2001).

Homer v. Commonwealth, 458 A.2d 1059 (Pa. Commw. Ct. 1983).

Horosko v. School District, 6 A.2d 866 (Pa. 1939).

In re Appeal of Morrill, 765 A.2d 699 (N.H. 2001).

In re Bay, 378 P.2d 558 (Or. 1963).

In re Grossman, 316 A.2d 39 (N.J. Super. Ct. App. Div. 1974).

In re Termination of Kibbe, 996 P.2d 419 (N.M. 1999).

In re Thomas, 926 S.W.2d 163 (Mo. Ct. App. 1996).

Jackson v. El Dorado School District, 48 S.W.3d 558 (Ark. Ct. App. 2001).

Jarvella v. Willoughby-Eastlake City School District, 233 N.E.2d 143 (Ohio Misc. 1967).

Jefferson County School District v. Fair Dismissals Appeals Board, 793 P.2d 888 (Or. Ct. App.1990).

Jefferson Union High School v. Jones, 100 Cal. Rptr. 73 (Cal. Ct. App. 1972).

Jenkyns v. Board of Education, 294 F.2d 269 (D.C. Cir. 1961).

Kenai Peninsula Borough Board of Education v. Brown, 691 P.2d 1034 (Alaska 1984).

Kinniry v. Abington School District, 673 A.2d 429 (Pa. Commw. Ct. 1996).

Laba v. Board of Education, 129 A.2d 273 (N.J. 1957).

Lang v. Lee, 639 S.W.2d 111 (Mo. Ct. App. 1982).

LaSota v. Town of Topsfield, 979 F.Supp. 45 (D. Mass. 1997).

Lee v. Weisman, 505 U.S. 577 (1992).

Lemon v. Kurtzman, 411 U.S. 192 (1973).

Lesley v. Oxford Area School District, 420 A.2d 764 (Pa. Commw. Ct. 1980). 
Lindgren v. Board of Trustees, 558 P.2d 468 (Mont. 1976).

Littlejohn v. Rose, 768 F.2d 765 (6th Cir. 1985).

Logan v. Warren County Board of Education, 549 F.Supp. 145 (S.D. Ga. 1982).

Lowenstein v. Newark Board of Education, 171 A.2d 265 (N.J. 1961).

Martin v. Santa Clara Unified School District, 125 Cal. Rptr. 2d (Cal. Ct. App. 2002).

Matter of Shelton, 408 N.W.2d 594 (Minn. Ct. App. 1987).

Matthews v. Eldridge, 424 U.S. 319 (1976).

McCullough v. Illinois State Board of Education, 562 N.E.2d 1233 (Ill. App. Ct. 1990).

McNeill v. Pinellas County School Board, 678 So. 2d 476 (Fla. Dist. Ct. App. 1996).

Meinhold v. Clark County School District, 506 P.2d 420 (Nev. 1073).

Melzer v. Board of Education, 336 F.3d 185 (2nd Cir. 2003).

Meredith v. Board of Education, 130 N.E.2d 5 (Ill. App. Ct. 1955).

Mescia v. Berry, 406 F.Supp. 1181 (S.C. 1974).

Miller v. California, 413 U.S. 15 (1973).

Montefusco v. Nassau County, 39 F.Supp.2d 231 (E.D.N.Y. 1999).

Morris v. Clarksville-Montgomery County Board of Education, 867 S.W.2d 324 (Tenn. Ct. App. 1993).

Morrison v. State Board of Education, 461 P.2d 375 (Cal. 1969).

Moser v. State Board of Education, 101 Cal. Rptr. 86 (Cal. Ct. App. 1972).

Mt. Healthy City School District v. Doyle, 429 U.S. 274 (1977).

NAACP v. Alabama ex rel Patterson, 357 U.S. 449 (1958).

National Gay Task Force v. Board of Education, 729 F.2d 1270 (10th Cir. 1984).

New Mexico State Board of Education v. Stoudt, 571 P.2d 1186 (N.M. 1977).

Newchurch v. Louisiana State Board, 713 So. 2d 1269 (La. Ct. App. 1998). 
Ott v. Board of Education, 389 A.2d 1001 (N.J. Super. Ct. App. Div. 1978).

Overton v. Goldsboro City Board of Education, 283 S.E.2d 495 (N.C. 1981).

Panzella v. River Trails School District, 729 N.E.2d 954 (Ill. App. Ct. 2000).

Paul v. Davis, 425 U.S. 985 (1976).

Perry v. Sindermann, 408 U.S. 593 (1972).

Perryman v. School Committee, 458 N.E.2d 748 (Mass. App. Ct. 1983).

Pettit v. State Board of Education, 513 P.2d 889 (Cal. 1973).

Pickering v. Board of Education, 391 U.S. 563 (1968).

Ponton v. Newport News School Board, 632 F.Supp. 1056 (E.D. Va. 1986).

Pordum v. Board of Regents, 357 F.Supp. 222 (N.D. N.Y. 1973).

Purifoy v. State Board of Education, 106 Cal. Rptr. 201 (Cal. Ct. App. 1973).

Purvis v. Marion County School Board, 766 So. 2d 492 (Fla. Dist. Ct. App. 2000).

Rackley v. School District, 258 F.Supp. 676 (D.S.C. 1966).

Randle v. Indianola Municipal Separate School District, 373 F.Supp. 766 (N.D. Miss. 1974).

Reinhardt v. Board of Education, 311 N.E.2d 710 (I1l. App. Ct. 1974).

Riforgiato v. Board of Education, 448 N.Y.S.2d 74 (N.Y. App. Div. 1982).

Roberts v. United States Jaycees, 468 U.S. 609 (1984).

Roe v. Wade, 410 U.S. 113 (1973).

Rogliano v. Fayette County Board of Education, 347 S.E.2d 220 (W. Va. 1986).

Ross v. Springfield School District, 691 P.2d 509 (Or. Ct. App. 1984).

Rowland v. Mad River Local School District, 730 F.2d 444 (6th Cir. 1984).

Salem-Keizer Association of Classified Employees v. Salem-Keizer School District, 61 P.3d 970 (Or. Ct. App. 2003). 
Sarac v. State Board of Education, 57 Cal. Rptr. 69 (Cal. Ct. App. 1967).

Satterfield v. Board of Education, 556 N.W.2d 888 (Mich. Ct. App. 1996).

Scott v. Board of Education, 156 N.E.2d 1 (IIl. App. Ct. 1959.

Scott v. Stewart, 560 S.E.2d 260 (W. Va. 2001).

Shelton v. Richmond Public Schools, 186 F.Supp.2d (E.D.Va. 2002).

Sherburne v. School Board, 455 So. $2 d 1057$ (Fla. Dist. Ct. App. 1984).

Shipley v. Salem School District, 669 P.2d 1172 (Or. Ct. App. 1983).

Skripchuk v. Austin, 379 A.2d 1142 (Del. Super. Ct. 1977).

Slater v. Pennsylvania Department of Education, 725 A.2d 1248 (Pa. Commw. Ct. 1999).

Smith v. King City School District, 990 S.W.2d 643 (Mo. Ct. App. 1998).

Snyder v. Massachusetts, 291 U.S. 97 (1934).

Startzel v. Commonwealth, 562 A.2d 1005 (Pa. Commw. Ct. 1989).

Stelzer v. State Board of Education, 595 N.E.2d 489 (Ohio Ct. App. 1991).

Sublett v. Sumter County School Board, 664 So. 2d 1178 (Fla. Dist. Ct. App. 1995).

Sullivan v. Meade Independent School District, 530 F.2d 799 (8th Cir. 1975).

Thompson v. Board of Education, 711 F.Supp. 394 (N.D. Ill 1989).

Thompson v. Southwest School District, 483 F.Supp. 1170 (W.D. Mo. 1980).

Thompson v. Wisconsin Department of Public Instruction, 541 N.W.2d 182 (Wis. Ct. App. 1995).

Tinker v. Des Moines Independent Community School District, 393 U.S. 503 (1969).

Tomerlin v. Dade County School Board, 318 So. 2d 159 (Fla. Dist. Ct. App. 1975).

Turk v. Franklin Special School District, 640 S.W.2d 218 (Tenn. 1982).

U.S. v. Morrison, 529 U.S. 598 (2000). 
U.S. v. Virginia, 418 U.S. 515 (1996).

Unzueta v. Ocean View School District, 8 Cal. Rptr.2d 614 (Cal. Ct. App. 1992).

Vogulkin v. State Board of Education, 15 Cal Rptr. 335 (Cal. Dist. Ct. App. 1961).

Von Durjais v. Board of Trustees, 148 Cal. Rptr. 192 (Cal. Ct. App. 1978).

Vukadinovich v. Board of School Trustees, 978 F.2d 403 (7th Cir. 1992).

Walton v. Turlington, 444 So. 2d 1082 (Fla. Dist. Ct. App. 1984).

Warren County School District v. Carlson, 418 A.2d 810 (Pa. Commw. Ct. 1980).

Watson v. State Board of Education, 90 Cal. Rptr. 468 (Cal. Ct. App. 1971).

Weaver v. Nebo School District, 29 F.Supp.2d 1279 (D.Utah 1998).

Williams v. Board of Public Instruction, 311 So. 2d 712 (Fla. Dist. Ct. App. 1975).

Williams v. School District, 417 P.2d 376 (Ariz. Ct. App. 1966).

Williams v. Sumter School District, 255 F.Supp. 397 (D.S.C. 1966).

Winters v. Arizona Board of Education, 83 P.3d 1114 (Ariz. Ct. App. 2004).

Wisconsin v. Constantineau, 400 U.S. 433 (1971).

Wishart v. McDonald, 367 F.Supp. 530 (D. Mass. 1973).

Woo v. Putnam County Board of Education, 504 S.E.2d 644 (W. Va. 1998).

Yanzick v. School District, 641 P.2d 431 (Mont. 1982).

Zelno v. Lincoln Intermediate Unit 12 Board of Directors, 786 A.2d 1022 (Pa. Commw. Ct. 2001).

\section{Other Legal Resources}

Civil Service Reform Act, 5 U.S.C. 1101 (1978). 


\section{CURRICULUM VITAE}

NAME: $\quad$ Ruth Louise Davison

ADDRESS: 947 South Fourth Street

Louisville, KY 40203

DOB: $\quad$ Philadelphia, Pennsylvania - July 8, 1965

EDUCATION

\& TRAINING: $\quad$ B.A., History \& World Religion

Mary Washington College

$1983-1987$

M.Div., Education Concentration

Southern Baptist Theological Seminary

1989 - 1993

M.A., Educational Administration

University of Louisville

$1998-2002$

Ph.D., Educational Administration

Concentration: Postsecondary Administration

University of Louisville

$1998-2004$

PUBLICATONS: $\quad$ Davison, R. L., Strope, J. L., \& Uerling, D. F. (2003). The personal lives and professional responsibilities of P-12 educators: Off-duty conduct as grounds for adverse employment actions. West's Education Law Reporter, 691 - 714.

Davison, R. L. \& Strope, J. L. (2001). Permission v. academic freedom and free speech: A review of Urofsky v. Gilmore. West's Education Law Reporter, 1 - 16. 